\title{
LIETUVOS KARIUOMENĖS TANKAI \\ IR JUৃ VAIDMUO VALSTYBĖS GYNYBOS \\ PLANUOSE XX A. 4-AJAME DEŠIMTMETYJE
}

\author{
Šarūnas Volungevičius \\ Vytauto Didžiojo universitetas
}

\section{İŽANGA}

Karo istorijoje Pirmasis pasaulinis karas jamžintas visų pirma dèl beprecedenčio destruktyvumo ir milžiniško aukų skaičiaus. Tačiau dar viena ryški šio konflikto ypatybė yra ta, kad jo metu pirmą kartą karybos istorijoje buvo panaudoti ginklai, kurie nuo to laiko ne tik itvirtino savo nepamainomą vaidmenị karybos teorijoje ir praktikoje, bet ir šiandien, praejus beveik šimtmečiui nuo šio karo pabaigos, yra vienas iš valstybès karinès galios simbolių ir svarbiausių sudedamųjų dalių. Vieni ryškiausių šių ginklų pavyzdžių yra tankai, pirmą kartą pasirodę šiaurès rytų Prancūzijos mūšio lauke 1916 m. rugsèji.

Po beveik dvejų metų Pirmojo pasaulinio karo pabaiga sudarè sąlygas atgimti Lietuvos valstybei ir vienam svarbiausiu jos suverenumo ir nepriklausomybės garantų - kariuomenei. Pirmieji Lietuvos Respublikos gyvavimo metai buvo pažymèti nenutrūkstamų kovų dèl Nepriklausomybès su išorès priešais, kèlusiais mirtiną grèsmę valstybès egzistencijai. Lietuvos kariuomenè suvaidino lemiamą vaidmenị apginant šalies nepriklausomybę ir tuo būdu patvirtino savo nenutrūkstamo stiprinimo ir vystymo būtinybę, kad valstybė galètų būti apginta ir ateityje. Nepriklausomybès kovų metu Lietuva dar neturejo savo tankų, tačiau šių palyginti naujų kovos mašinų neginčijamai reikšmingas vaidmuo Pirmajame pasauliniame kare lėmé, kad ir tuometė Lietuvos karinè vadovybė suprato jų svarbą mūšio lauke ir siekiant sukurti modernias ir stiprias ginkluotąsias pajègas.

Nuo pat pradžių, kai tik atsirado Lietuvos kariuomenès arsenale, tankai tapo išskirtine sausumos pajègų dalimi. Pirmosios Lietuvos Respublikos sausumos pajègų palyginti ribotos mechanizacijos ir motorizacijos kontekste tankai buvo ypatingi karo technikos vienetai ne tik dèl išskir- 
tinès konstrukcijos, bet ir vaidmens, kuris buvo jiems numatytas galimų karo veiksmų atveju. Kaip ir pagrindinėms Lietuvos kariuomenès ginklo rūšims, tankams, atsižvelgiant ị jų konstrukcijos ir ginkluotès ypatybes, iš anksto buvo numatytos specifinès kovinès užduotys, jų vykdymo būdai ir taktika. Tankų, kurie buvo gana brangi karo technika, Lietuvos kariuomenè negalejo daug tureti. Nepaisant to, jie buvo suvokiami ne tik kaip kone būtinas modernių sausumos pajègų elementas, bet ir visų pirma kaip svarbus pagrindinių manevrinių dalinių paramos ginklas, jų kovinès galios daugiklis. Atsižvelgiant ị tankams numatytą vaidmenị kovos lauke, esminiu tapo šių šarvuotųjų kovos mašinų kovinès vertès, suformuotos kelių tarpusavyje susijusių veiksnių, klausimas.

Pastaraisiais metais galima pastebèti išaugusị tyrèjų susidomèjimą ir su tuo susijusius darbus apie pirmosios Lietuvos Respublikos kariuomenès ginkluotųjų pajègų rūšis, dalinius ir pasirinktus technikos vienetus ${ }^{1}$. Nors Lietuvos kariuomenès tankai jau yra sulaukę istorikų dėmesio, ši tema dar toli gražu nèra visiškai ištirta, ypač jei kalbètume apie šių kovos mašinų kovinę vertę, vietą ir vaidmenị, taip pat kovos veiksmus galimose karinèse operacijose.

Visų pirma norètųsi paminèti dar 1939 m. pasirodžiusį veikalą, skirtą visų tarpukario Lietuvos kariuomenès karo technikos dalinių ligtolinei istorijai, kuriame žinių apie tankus pateikta vis dèlto mažai: palyginti trumpai aprašoma, kaip jie buvo įsigyti ir įtraukti ị kariuomenès sudètį, tačiau gana išsamiai - kaip vyko šarvuotụjų pajègų (taip pat ir tankų) padalinių karių mokymas². Šis leidinys išsiskiria ir išsamia bibliografija, kurioje, be kita ko, galima rasti nuorodas ị visus iki to laikotarpio tarpukario Lietuvos karinèje spaudoje pasirodžiusius straipsnius, skirtus šar-

1 G. Surgailis, Pirmasis péstininkų Didžiojo Lietuvos kunigaikščio Gedimino pulkas, Vilnius, 2011, 305 p.; G. Surgailis, Trečiasis péstininku Didžiojo Lietuvos kunigaikščio Vytauto pulkas, Vilnius, 2013, 192 p.; G. Surgailis, Antrasis Lietuvos didžiojo kunigaikščio Algirdo pulkas, Vilnius, 2014, 292 p.; G. Surgailis, Ketvirtasis péstininku Lietuvos karaliaus Mindaugo pulkas, Vilnius, 2016, 277 p.; V. Grigoraitis, Lietuvos kariuomenès technika: sunkvežimiai, Karo archyvas, t. 16, Vilnius, 2000, p. 151-182; V. Edvinas, Priešlèktuvinès apsaugos rinktinė 1935-1940 m., Karo archyvas, t. 25, Vilnius, 2010, p. 214-248; V. Jokubauskas, E. Papečkys, Lietuvos kariuomenès artilerijos pabūklai 1919-1940 m., Karo archyvas, t. 27, Vilnius, 2012, p. 163-231; V. Jokubauskas, Lietuvos kariuomenès kavalerija tarpukariu: reguliarieji pulkai, šauliai dragūnai ir teritorinių dragūnų tarnyba, Karo archyvas, t. 30, Vilnius, 2015, p. 238-288.

2 Karo technikos dalių dvidešimtmetis 1919-1939, Kaunas, 1939, 423 p. 
vuotųjų pajègų temai. Taip pat reikètų paminèti Vytenio Statkaus gerai žinomą veikalą apie Lietuvos Respublikos ginkluotąsias pajègas, kuriame tankams, tiesa, nèra skiriama daug dèmesio, tik glaustai apibūdinami jų isigijimo procesai, techniniai duomenys ir kiti smulkūs faktai ${ }^{3}$.

Išsamiame Vido Grigoraičio veikale apie tarpukario Lietuvos kariuomenès techniką daugiausia dèmesio skiriama tankų ịsigijimo planams, procesams, kiekvieno atskiro šių kovos mašinų modelio techninėms charakteristikoms ir tarnybos istorijai ${ }^{4}$.

Doc. dr. Vytautas Lesčius savo plačiame straipsnyje apie paskutinių dvejų pirmosios Lietuvos Respublikos gyvavimo metų kariuomenės organizacijos, dislokacijos ir ginkluotės pokyčius taip pat aptarè šio laikotarpio Šarvuočių rinktinès ir ją sudariusių tankų padalinių veiklą, organizaciją, sudètị ir pajègumą ${ }^{5}$.

Savo išsamiuose darbuose apie tarpukario Lietuvos kariuomenès ir valstybès karinę galią, karinę doktriną dr. Vytautas Jokubauskas taip pat palietė tankų temą, ne tik aptardamas jų ìsigijimo istoriją, bet ir, svarbiausia, atkreipdamas dèmesị ị tankų vaidmenị kovos lauke bei jų pajègú plètros planus ${ }^{6}$.

Dr. Andriejaus Stoliarovo ir Arvydo Pociūno albumas apie pirmosios Lietuvos Respublikos kariuomenès tankus yra ne tik naujausias indèlis $\mathfrak{i}$ šios tematikos istoriografiją, bet ir bene pirmasis išskirtinai minèto laikotarpio Lietuvos ginkluotųjų pajègų tankų istoriją nagrinejjantis veikalas ${ }^{7}$. Jame detaliai pristatoma Lietuvos kariuomenès tankų junginių struktūra, sudètis, sausumos pajègų turètų ir planuotų ìsigyti tankų konstrukcija, taip pat atkreipiamas demesys ị kariuomeneje organizuotą su tankais susijusị kovinị rengimą, kovos mašinų ir jų dalinių karių likimus po pirmosios Lietuvos sovietinès okupacijos. Be to, šị leidinị praturtina itin gau-

\footnotetext{
3 V. Statkus, Lietuvos ginkluotosios pajegos 1918-1940 m., Chicago, 1986, 1040 p.

4 V. Grigoraitis, Lietuvos kariuomenès technika 1918-1940, Vilnius, 2009, 271 p.

5 V. Lesčius, Lietuvos kariuomenès organizavimo, dislokavimo ir ginkluotès pokyčiai 1938-1940 m., Karo archyvas, t. 24, Vilnius, 2009, p. 116-205.

6 V. Jokubauskas, „Mažujų kariuomeniu““ galia ir paramilitarizmas. Tarpukario Lietuvos atvejis, Klaipėda, 2014, 587 p.; V. Jokubauskas, Karinė doktrina: tarpukario Lietuvos kariuomenès atvejis (1923-1940 m.), Karo archyvas, t. 29, Vilnius, 2014, p. 120-188.

7 A. Pociūnas, A. Stoliarovas, Tankai Lietuvos kariuomeneje 1924-1940 m., Vilnius, 2015, 148 p.
} 
sios iliustracijos - tarpukario Lietuvos kariuomenès tankų nuotraukos.

Vertingos informacijos suteikia ir Dalios Bukelevičiūtès išsami monografija apie dvišalius Lietuvos ir Čekoslovakijos santykius (įskaitant ir karinị bendradarbiavimą) 1918-1939 m., kadangi būtent su pastarosios valstybès karo pramonès sukurtais tankais Lietuvos kariuomenè siejo savo šarvuotụjų pajègų modernizavimo planus $1937-1940 \mathrm{~m} .^{8}$

Šio darbo tikslas - ištirti Lietuvos kariuomenès tankų kovinius pajègumus, šių karo technikos vienetų vietą ir vaidmenị galimuose kariniuose veiksmuose XX a. 4-ajame dešimtmetyje, kai Lietuvos šarvuotosios pajègos išgyveno sparčiausią plètros etapą. Straipsnyje siekiama išanalizuoti Lietuvos sausumos pajègų sudètyje buvusių tankų modelių konstrukcijos savybes ir jų techninès būklès kaitą, apibūdinti ịvairius tankų igulų ir padalinių mokymo ir kovinio rengimo aspektus ir problemas, išnagrinèti tankų panaudojimo vykdant kovos užduotis Lietuvos kariuomeneje teorinius pagrindus ir palyginti juos su per pratybas išryškejusiais rezultatais, aptarti Lietuvos kariuomenès tankų pajègų pageidautinos tolesnès plètros planus.

Rengiant ši straipsnị daugiausia remtasi Lietuvos centriniame valstybès archyve (LCVA) saugomais dokumentais: fonde Nr. 509 sukaupta I pèstininkų divizijos, Nr. 538 - Gaižiūnų poligono štabo, Nr. 828 - Šarvuočių rinktinès, Nr. 929 - Kariuomenès štabo, Nr. 1364 - Karo technikos valdybos dokumentacija. Ne mažiau svarbūs tyrimui buvo ir publikuoti šaltiniai, tiksliau - trijų pagrindinių tarpukario Lietuvos kariuomenès statutų - Pėstininkų, Kavalerijos ir Artilerijos - antrosios dalys, reglamentavusios šių sausumos pajègų rūšių kautynių veiksmus ir jų kovinị bendradarbiavimą su tankais ${ }^{9}$. Minètų šaltinių informaciją papildè, neskaitant istoriografijos, straipsniai tarpukario karinèje periodinèje spaudoje - leidiniuose „Mūsų žinynas“, „Kardas“ ir „Karys“.

8 D. Bukelevičiūtè, Lietuvos ir Čekoslovakijos dvišalių santykių dinamika 1918-1939 metais, Vilnius, 2010, $342 \mathrm{p}$.

9 Péstininku statutas P-51, II dalis. Kautynès. 2 laida, Kaunas, 1939, 460 p.; Kavalerijos statutas K-51, II dalis. Kautynès, Kaunas, 1938, 544 p.; Artilerijos statutas A-51, II dalis. Kautynes, Kaunas, 1937, 314 p. 


\section{LIETUVOS KARIUOMENĖS TANKUุ MODELIAI, İSIGIJIMO APLINKYBĖS, TECHNINĖS SAVYBĖS, EKSPLOATACIJA}

\subsection{Lengvieji tankai „Renault FT 17“}

Kalbant apie tankų padalinių kovinius pajègumus, pirmuoju iš juos lemiančių veiksnių galima ịvardyti šios karo technikos technines savybes. Konkretaus modelio tanko konstrukcija iš esmès lemia, kaip ir kokioms kovinèms užduotims atlikti jis gali būti naudojamas. Tiesa, ne mažiau svarbus aspektas - šių kovos mašinų techninė priežiūra. Ši sritis nepaprastai svarbi, norint ịvertinti realias, o ne nominalias tankų galimybes ir pasirengimą sklandžiai veikti ginkluotojo konflikto metu, kadangi dèl neišspręstų vienų ar kitų konstrukcijos dalių susidèvejimo ar gedimo problemų jie tiesiog nebus pajègūs dalyvauti karo veiksmuose. Tinkamam tankų, kaip ir visos kitos karo technikos, naudojimui tiek taikos, tiek karo metu didelę reikšmę turi jų personalo (karių) parengimo kokybè.

Tankų ìsigijimo procesas Lietuvos kariuomenejje, nepaisant sunkios šalies ekonominès padèties ir ribotų biudžeto lèšų, prasidejjo jau po Nepriklausomybès kovų, 1923 m. Tankams pirkti buvo skirta 900 tūkst. auksinų. Neilgai trukus, Prancūzijoje buvo įsigyta dvylika tankų „Renault FT 17“. Šie pirmieji Lietuvos kariuomenès tankai buvo pagaminti 1917 m. ir jau naudoti Pirmajame pasauliniame kare ${ }^{10}$.

Lengvasis tankas „Renault FT 17 “ svèrè $6,5 \mathrm{t}$, buvo 2,14 $\mathrm{m}$ aukščio, $1,74 \mathrm{~m}$ pločio ir $5 \mathrm{~m}$ ilgio (kartu su prie mašinos galo pritaisoma ir vietovès kliūtis įveikti padedančia atspara, be jos $-4,10 \mathrm{~m}$ ), prošvaisa (tarpas tarp tanko apačios ir žemès) $-43 \mathrm{~cm}$, vikšrų plotis $-34 \mathrm{~cm}$. Keturių cilindrų 36 AG variklis padėdavo pasiekti didžiausią $8 \mathrm{~km} / \mathrm{val}$. greitị ir, nepapildžius degalų, nuvažiuoti 45-50 km. Skysčiu aušinamame variklyje, nuvažiavus $4 \mathrm{~km}$, dèl perkaitimo grèsmès būtinai reikèjo keisti vandenị ir tai turèjo užtrukti apie $20 \mathrm{~min}$. Degalų bake esančio benzino užtekdavo 10 val. „Re-

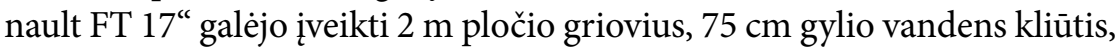
$45^{\circ}$ statumo įkalnes, $65 \mathrm{~cm}$ aukščio stačias sieneles, nulaužti iki $25 \mathrm{~cm}$ storio medị. Tanko šarvų storis, priklausomai nuo vietos, ̨̣vairavo: horizonta-

10 V. Grigoraitis, Lietuvos kariuomenès technika 1918-1940 m., p. 103. 
lių sienelių siekè $6 \mathrm{~mm}$, vertikalių - nuo 8 iki $16 \mathrm{~mm}$, bokštelis buvo apsaugotas 22,5 mm storio šarvų. Jo igulą sudarè 2 žmonès - vairuotojas ir tanko vadas, jų vietos atitinkamai buvo tanko korpuso priekyje ir bokštelyje. Lietuvos kariuomenès tankai „Renault“ buvo ginkluoti sunkiaisiais „Maxim“ sistemos kulkosvaidžiais su 3000 šovinių koviniu komplektu, nors galëjo būti apginkluoti ir sunkesne ginkluote, pvz., $37 \mathrm{~mm}$ pabūklais ${ }^{11}$.

Praejjus kiek daugiau nei dešimčiai metų, kai buvo įsigyta šių kovos mašinų, t. y. 1934 m., kelių kariuomenès dalinių ir padalinių vadai raportavo apie jau kone kritiškai prastą pirmụjų Lietuvos tankų techninę būklę ${ }^{12}$. Pirmiausia čia tenka paminèti išsamų $1934 \mathrm{~m}$. kovo mèn. tankų kuopos vado raportą savo tiesioginiam viršininkui, Šarvuočių rinktinès vadui, atskleidžiantị tuo metu jo vadovaujamam padaliniui ịvairiose srityse kilusias problemas ${ }^{13}$. Pirmoji iš jų buvo tiesiogiai susijusi su technine tankų kovinio pajejgumo puse, t. y. pagrindine ginkluote - sunkiaisiais kulkosvaidžiais. Raporte nurodyta, kad visi 22 tankų kuopoje esantys kulkosvaidžiai, ypač jų vamzdžiai, dèl susidèvejjimo yra blogos būklès. Ši problema gerokai mažino ginklų taiklumą ir patikimumą, nes dèl to jie dažnai užsikirsdavo. Kaip pažymèjo kuopos vadas, net ir patyrusiems kulkosvaidininkams atitikti mokomųjų ir kautynių pratimų reikalavimus šaudant iš tokių ginklų yra beveik neįmanoma ${ }^{14}$.

Negana to, raporte taip pat minima keletas tankų konstrukcijos ir atskirų jos dalių problemų, kurios trukdè tinkamai atlikti taktikos pratimus per manevrus ir, be abejo, būtų itin neigiamai paveikusios tankų galimybes sèkmingai veikti ginkluoto konflikto atveju. Pirma, jų seni ir susidèvèję mechanizmai dažnai gesdavo. Antroji problema, ypač kenkianti „Renault FT 17“ mobilumui, buvo itin blogas variklio aušinimas ir dèl to kylanti perkaitimo grèsmè. Dèl to ilgai trunkantị variklio aušinimo vandens keitimo - procesą tekdavo pradèti pavažiavus vos 15-20 min.

111940 balandžio mèn. Lietuvos kariuomenès tankų duomenys, Lietuvos centrinis valstybés archyvas (toliau - LCVA), f. 828, ap. 1, b. 141, 1. 1; 1935-09-17 tanko „Reno“ duomenys, $L C V A$, f. 828 , ap. 1, b. 141, 1. 2; „Reno“ lengvojo tanko aprašymas, $L C V A$, f. 828, ap. 1, b. 141, 1. 4; A. Pociūnas, A. Stoliarovas, min. veik., p. 18-19.

12 1934-03-12 raportas Rinktinès vadui, $L C V A$, f. 828, ap. 1, b. 74, 1. 26-27; 1934-09-21 raportas Karo technikos viršininkui, $L C V A$, f. 828, ap. 1, b. 74, 1. 117.

13 1934-03-12 raportas Rinktinès vadui, $L C V A$, f. 828, ap. 1, b. 74, 1. 25-27.

14 Ten pat, 1. 26. 
Negana to, Lietuvos kariuomenès tankų radiatoriai ir benzino bakai rūdijo, užsiteršdavo ir prakiurdavo, rimta problema buvo per mažas jų greitis $^{15}$. Kad ši nepaprastai bloga padètis pasikeistų, kuopos vado nuomone, buvo būtina atlikti kapitalinị tankų remontą, nes iki tol nuolat atliekamas smulkus remontas nebuvo veiksmingas, bet brangus, tad su laiku jo kaina vis tiek būtų prilygusi arba net ir pranokusi kapitalinio remonto kainą ${ }^{16}$.

1934 m. rugsėjo mėn. raporte karo technikos viršininkui Šarvuočiu rinktinès, kuriai ir priklausė tankų kuopa, vadas taip pat pabrěžè šarvuotųjų kovos mašinų kapitalinio remonto būtinybę, kartu nurodydamas, kad jų dalys susidèvejjusios ir nèra naujų atsarginių dalių. Tokia prasta tankų „Renault" techninè būklè buvo viena iš pagrindinių priežasčių, dèl kurios, Šarvuočių rinktinès vado nuomone, dalinys, kurio pagrindinè kovinè jèga ir turèjo būti tankai, tuo metu nebūtų galèjęs ịvykdyti kariuomenès vadovybės jam keliamų operatyvinių uždavinių ${ }^{17}$.

Apie bandymus pakeisti taip blogai susiklosčiusią padèti sužinome iš 1936 m. gegužès mèn. tuometinio Šarvuočių rinktinès vado gen. št. plk. ltn. Antano Sidabro raporto karo technikos viršininkui, kuriame, be kita ko, pranešama apie atliktus tankų remonto darbus ir jų bandymų rezultatus ${ }^{18}$. Šiais remonto darbais, regis, pirmiausia buvo siekiama išspręsti mažos galios ir susidèvèjusių variklių keliamas problemas ir taip padidinti tankų mobilumą ir patikimumą. Raporte konkrečiai nenurodyta, kokie remonto darbai atlikti, tačiau pateikti pozityvūs trijų pirmųjų suremontuotų „Renault FT 17“ bandymų rezultatai: jų didžiausias greitis padidejjo iki 12,6 km/val., o variklių aušinimo vanduo neužvirè net ir po aštuonių valandų nepertraukiamo darbo ${ }^{19}$. Rinktinès vado nuomone, šitaip suremontavus ir likusius devynis „Renault“, pirmosios tankų kuopos kovos mašinos būtų tinkamos dalyvauti kovos veiksmuose. Tiesa, nors remonto rezultatai ir buvo geri, gen. št. plk. ltn. A. Sidabras labiausiai akcentavo būtinybę bent dalị šių tankų perginkluoti priešo šarvuotąją techniką sunaikinti galinčiais pabūklais ${ }^{20}$.

\footnotetext{
15 Ten pat, 1. 26 a. p.

16 Ten pat, 1.26 a. p.-27.

17 1934-09-21 raportas karo technikos viršininkui, LCVA, f. 828, ap. 1, b. 74, 1. 117.

18 1936-05-14 raportas karo technikos viršininkui, LCVA, f. 828, ap. 1, b. 109, 1. 33.

19 Ten pat, 1. 33 .

20 Ten pat, 1. 33 .
} 


\subsection{3 m. modelio lengvieji tankai „Vickers-Carden Loyd“}

Naujos šarvuotosios technikos Lietuvos kariuomenei paieška prasidèjo 1928 m., kai spalio 6 d. krašto apsaugos ministro ịsakymu buvo sudaryta komisija, turinti vykti ị Didžiąją Britaniją, Belgiją, Prancūziją, Italiją, Čekoslovakiją ir Vokietiją susipažinti su šių valstybių firmų gaminamais šarvuotaisiais automobiliais, tankais, žvalgybos, ryšių ir kitomis šarvuotosiomis kovos mašinomis. Komisija, kurią sudarè plk. ltn. Aleksandras Plechavičius (pirmininkas), mjr. Juozas Barzda-Bradauskas ir kpt. Vincas Asevičius, apsilankiusi D. Britanijos firmose „Vickers“, „Rolls-Royce“, „Crossley“ ir „Lanchester“, prancūzų - „Saurer“, „Citroen“, „Berliet“, „Renault“, italų - „Fiat“, čekoslovakų - „Škoda“, „Tatra“ ir kt., 1928 m. lapkričio 19 d. parengè santrauką šių užsienio gamintojų pasiūlymų, kuriuose buvo pristatyti karinès technikos modeliai, jų ypatybès, pranašumai, trūkumai, pateiktos išvados dèl jų tinkamumo Lietuvos kariuomenei ${ }^{21}$.

Svarbiausia komisijos užduotis, regis, buvo rasti tinkamiausią Lietuvos kariuomenès kavalerijai skirtą šarvuotąj t automobilị. Buvo susipažinta su firmų „Vickers", „Renault" ir „Fiat“ siūlomais lengvaisiais ir vidutiniais tankais. Palankiausiai ịvertinti, atrodo, buvo firmų „Renault“ ir „Fiat“ lengvieji tankai, turintys daug panašumų, tiek lyginant tarpusavyje, tiek su Lietuvos kariuomenès „Renault FT 17“. Tiesa, pastarąsias mašinas du anksčiau minèti tankai lenkè tokiomis techninemis savybèmis kaip greitis, variklio galingumas, igulos darbo sąlygos ${ }^{22}$. Vis dèlto tąkart nei nauju tankų, nei šarvuotųjų automobilių Lietuvos kariuomenẻ neįsigijo.

Mèginimai modernizuoti Lietuvos kariuomenès šarvuotosios technikos parką buvo atnaujinti jau XX a. ketvirtojo dešimtmečio pradžioje. Pirmieji žingsniai šia kryptimi buvo žengti 1932 m., kai tų pačių metų lapkričio 16 d. karo technikos viršininko iš Karo technikos tiekimo skyriaus viršininko plk. ltn. Kazio Jonūno (pirmininkas), Šarvuočių rinktinès vado mjr. V. Asevičiaus ir šios rinktinès mjr. Alfonso Urbono sudaryta komisija svarstė naujų šarvuočių ir tankečių (lengvųjų tankų) pirkimo klausimą ${ }^{23}$. Kariuomenès vertinimui tąkart savo gaminamų šarvuočių ir tankečių pasiūlymus pateikè aštuonios užsienio firmos: Didžiosios Brita-

21 1928-11-19 aktas, LCVA, f. 828, ap. 1, b. 44, 1. 6-10.

22 Ten pat, 1.8 a. p.

23 1932-11-16 aktas Nr. 100, LCVA, f. 1364, ap. 3, b. 89, 1. 36-37 a. p. 
nijos „Vickers Armstrongs“, Italijos „Fiat Ansaldo“, Prancūzijos „Berliet“ ir „Renault“, Nyderlandų „Siderius“, Šveicarijos „Vafenfabrik Solothurn“, Švedijos „Landsverk“, Vokietijos „Beni Spiro“. Iš visų pateiktų pasiūlymų komisija išskyrè keturis, labiausiai svarstytinus, kuriuos pateike firmos „Fiat Ansaldo“, „Beni Spiro“, „Renault“ ir „Vickers Armstrongs“24.

Išanalizavus šiuos pasiūlymus, prieita prie išvados, kad visi keturi tankečių modeliai techniniu požiūriu yra beveik vienodi, nors geriausiu buvo laikomas firmos „Fiat Ansaldo“ variantas. Šio modelio kovos mašinos gabaritai buvo mažesni (dèl to tanketè sunkiau pastebima), turèjo dvigubo valdymo galimybę (dèl ko vienodai lengvai buvo galima važiuoti tiek i priekí, tiek atbulomis), geriau šarvuota. Turédama tai omenyje, komisija rekomendavo, atsižvelgiant ị geresnius techninius parametrus, issigyti būtent firmos „Fiat Ansaldo“ gaminamų tankečių, nors taip pat paminèjo, kad dèl kainos parankiausias būtų firmos „Vickers“variantas ${ }^{25}$. Ko gero, būtent ši, mažiausios kainos, aplinkybè ir lèmé, kad Lietuvos kariuomenès šarvuotosios technikos parkui atnaujinti ir papildyti galiausiai buvo pasirinkta kompanijos „Vickers Armstrongs“ technika. 1933 m. gruodžio $9 \mathrm{~d}$. Karo technikos tiekimo skyriaus viršininkas plk. K. Jonūnas ir kompanijos „Vickers“ igaliotinis pasirašè sutartị, kuria ši D. Britanijos firma ịsipareigojo pristatyti 16 tankečių su ginkluote, amunicija ir atsarginėmis dalimis, Lietuvai už šią techniką sumokejjus 42600 svarų ir 6 šilingus ${ }^{26}$. Taip $1935 \mathrm{~m}$. vasario $4 \mathrm{~d}$. Šarvuočių rinktinès žinion buvo galutinai perduotos naujosios Lietuvos kariuomenès šarvuotosios mašinos - 1933 m. modelio „Vickers-Carden Loyd“ tanketès (lengvieji tankai), kurios Lietuvos biudžetui iš viso kainavo beveik 1,3 mln. $\mathrm{Lt}^{27}$.

Lengvasis tankas (dokumentuose ir istoriografijoje dažnai dar ịvardijamas kaip tanketè) „Vickers-Carden Loyd“ (VCL) svèrè 3,8 t (su ginkluote ir igula), jo aukštis siekè $188 \mathrm{~cm}$, plotis $-190 \mathrm{~cm}$, ilgis $-365 \mathrm{~cm}$, prošvaisa $-26 \mathrm{~cm}$. Tankas, turèdamas 6 cilindrų, $56 \mathrm{AG}$, skysčiu aušinamą variklị, galèjo pasiekti didžiausią $45 \mathrm{~km} /$ val. greitị, ịveikti $45^{\circ}$ ikalnes, 1,5 m pločio griovius ir 0,6 m aukščio stačias sieneles. Mašina iš

\footnotetext{
24 Ten pat, 1. 36 .

25 Ten pat, 1. 36.

26 V. Grigoraitis, Lietuvos kariuomenès technika 1918-1940 m., p. 109.

27 Ten pat, p. 110.
} 
viso turejo 6 pavaras - 5 priekines ir 1 atbulinę. Pripylus pilną baką ir nepapildant degalų, keliais galejo nuvažiuoti 200-300, o raižyta vietove $70-100 \mathrm{~km}$. Be degalų bake telpančių 97,81 benzino, dar buvo gabenama 20,45 1 tepalo ir 15,9 1 aušinimo vandens. „Vickers-Carden Loyd“ buvo ginkluotas vienu sunkiuoju „Vickers“ sistemos kulkosvaidžiu, jo šarvų storis - nuo 6 iki $9 \mathrm{~mm}$, igulos, kurią sudarè du žmonès - vairuotojas ir tanko vadas, vietos atitinkamai įrengtos tanko priešakyje ir bokštelyje ${ }^{28}$.

Visi šešiolika naujųjų Lietuvos kariuomenès lengvųjų tankų „VickersCarden Loyd“ buvo skirti 1935 m. liepos 31 d. suformuotai Šarvuočiu rinktinès 2-ajai tankų kuopai, sudarytai iš trijų būrių po penkis tankus kiekviename (vienas tankas teko kuopos vadui) ${ }^{29}$. Jau palyginti anksti šių kovos mašinų tarnyboje kilo tam tikrų problemų, kurių svarbiausiu šaltiniu, regis, buvo ne kokie nors techniniai defektai, o personalo, kuriam jos buvo patikètos, parengimo trūkumai ir klaidos. 1936 m. spalio 21 d. 2-osios tankų kuopos vadas kpt. Nikodemas Migevičius Šarvuočių rinktinès vadui pranešè, jog po pasikalbejjimo su rinktinès dirbtuvių viršininku paaiškejjo, kad visų jo vadovaujamo padalinio tankų tam tikros važiuoklès dalys (ritinèliai, vežimèliai) jau nudilusios ir klibančios ${ }^{30}$. Vadinasi, neatlikus remonto, ilgesnị laiką šiais tankais važinèti nebus galima. Kuopos vadas nurodė ir šios problemos priežastị - prastą karių teorinị pasirengimą, neleidusị jiems gerai susipažinti su tankų ypatumais ir neigiamai atsiliepusị gebejjimui praktiškai juos valdyti, vairuoti. Dèl netinkamo tankų valdymo neracionaliai buvo eikvojami šarvuotųjų mašinų techniniai resursai, todèl jos dažniau gedo ${ }^{31}$. Tiesa, dar tų pačių metų (1936-ųjų) kariuomenès rudens manevrų metu lengvieji tankai VCL veikè palyginti gerai, ne taip dažnai ir rimtai gedo ${ }^{32}$. Pavyzdžiui, vieno iš manevruose dalyvavusių aptariamụjų tankų būrių sugedo vieno tanko

\footnotetext{
281940 balandžio mèn. Lietuvos kariuomenès tankų duomenys, LCVA, f. 828, ap. 1, b. 141, 1. 1; 1935-09-17 lengvojo tanko duomenys, LCVA, f. 828, ap. 1, b. 141, 1. 2; Lengvos tanketès „Vickers-Carden Loyd“ aprašymas, $L C V A$, f. 828, ap. 1, b. 141, 1. 4-4 a. p; A. Pociūnas, A. Stoliarovas, Tankai Lietuvos kariuomenèje 1924-1940 m., p. 20.

29 V. Grigoraitis, Lietuvos kariuomenes technika 1918-1940 m., p. 111.

30 1936-10-21 raportas Rinktinès vadui, $L C V A$, f. 828, ap. 1, b. 109, 1. 119 a. p.

31 Ten pat, 1. 119-119 a. p.

32 1936-10-07 Šarvuočių rinktinès vado raportas karo technikos viršininkui, LCVA, f. 828 , ap. 1, b. $109,1.107$ a. p.
} 
starterio vienakrypté mova - „bendiksas“ (varikli teko paleisti sukant rankeną), kito tanko nutrūko lingiu lapo „auskaras“, o dar vieno - atsipalaidavo vikšras (pastaraisiais dviem atvejais gedimai buvo pašalinti vietoje) $)^{33}$. Tuo pat metu senesni „Renault FT 17“ i poligoną atvyko tokios būklès, kad jų buvo neįmanoma naudoti „sujungtų ginklų“ (t. y. bendradarbiaujant su kitomis pajègų rūšimis) pratybose ${ }^{34}$.

Jau kitais metais, $1937 \mathrm{~m}$. liepos $8 \mathrm{~d}$. duomenimis, tankai „VickersCarden Loyd" atrodè esantys pakankamai geros būklès, kad galètų būti aktyviai panaudoti kilus pavojui ${ }^{35}$. Tokią išvadą iš pirmo žvilgsnio leidžia padaryti minètą dieną sudaryta duomenų suvestinè apie Šarvuočių rinktinès pasirengimą išvykti iš nuolatinès dislokacijos vietos Radviliškyje, kilus pavojui valstybès saugumui. Joje pateikta informacija rodo, kad iš šešiolikos 2-osios tankų kuopos VCL prireikus per 1-3 valandas nuo įsakymo paskelbimo išvykti galèjo 15, o 1 tankas buvo paliekamas nuolatinès dislokacijos vietoje apsaugai ir tarnybai. Tai labai skyrèsi nuo 1-osios tankų kuopos „Renault FT 17“ (iš viso 12 kovos mašinų) duomenų, kadangi net 9 jos tankai apibūdinti kaip negalintys išvykti, o 3 - taip pat paliekami apsaugai ir tarnybai ${ }^{36}$. Tiesa, kaip paaiškèjo iš tų pačių metų lapkričio mèn. sudaryto 2-osios tankų kuopos vado kpt. N. Migevičiaus raporto, tai, kad praktiškai visi VCL galëjo išvykti pavojaus atveju, dar nereiškè, kad šie tankai iš tiesų buvo geros techninès būklès ${ }^{37}$. Minètame pranešime nurodoma, kad vos penki tankai buvo visiškai tvarkingi, o net dešimt (beveik du trečdaliai kuopos kovos mašinų) reikèjo iš pagrindụ suremontuoti, t. y. išardyti, netinkamai veikiančias dalis sureguliuoti arba pakeisti naujomis ir pašalinti kitus trūkumus. Tokia padètis neigiamai atsiliepé 2-osios tankų kuopos galimybèms sudaryti reikalaujamo pajègumo parengties dalini, galintį reaguoti paskelbus pavojų. Pasak kpt. N. Mi-

331936 m. Kariuomenès manevruose tankeliams „mèlynųjų“ puseje duoti uždaviniai, uždavinius vykdant pastebèti netikslumai ir bendros pastabos manevruose, LCVA, f. 828, ap. 1, b. 109, l. 102.

34 1936-10-27 Šaudymų ir taktiškų lauko pratimų 1936 metų Gaižiūnų poligono I-me laikotarpyje išdavos, LCVA, f. 509, ap. 1, b. 321, 1. 27.

35 1937-07-08 Žinios apie Šarvuočiu rinktinès parengimą išvykti pavojui ištikus, LCVA, f. 828 , ap. 1, b. 131, l. 42 .

36 Ten pat, 1. 42.

3719371111 raportas Technikos skyriaus viršininkui, LCVA, f. 828, ap. 1, b. 150, 1. 64-64 a. p. 
gevičiaus, ši dalinị turejjo sudaryti 10 jo vadovaujamos kuopos tankų (du tankų būriai), o tai reiškè, kad pusè dalinio turèjo būti sukomplektuota iš remontuotinų kovos mašinų. Vadinasi, kuopos vado nuomone, galima tikètis, kad nurodytas pozicijas nesugedę pakeliui pasieks vos penki iš dešimties parengties dalinio „Vickers-Carden Loyd“ tankų ${ }^{38}$. Negana to, tokia būklè kenkè ir mokymams, kuriuose dalyvavo tankų padaliniai, kadangi, pasak kpt. N. Migevičiaus, techniškai netvarkingos mašinos daugiau ar mažiau gesdavo beveik po kiekvieno pratimo, o karo technikos dirbtuvès nebuvo pajėgios sparčiai suremontuoti sugedusių tankų ${ }^{39}$.

$\mathrm{Su}$ „Vickers-Carden Loyd“ patiriamų gedimų šaltiniais geriau supažindina 1938 m. gegužę technikos dirbtuvių viršininko ltn. Kazio Varkalio sudarytas detalus trūkumų ir konstrukcinių netobulumų, pastebètu remontuojant tankus, sąrašas ${ }^{40}$. Dokumente išskirtos kelios probleminès sritys: varikliai (susidèvèję stūmokliai, alkūniniai velenai, švaistikliniai guoliai, vožtuvai, smagračių krumpliaračiai, ventiliatorių poveržlès, šratiniai guoliai), kūginė pavara ir darbo ratai (nepatikimi odiniai tepalo žiedai, atramų neturinčios kūginès pavaros, nepakankamai sutepti darbo ratai), radiatoriai (jiems kenkẻ prasta tanko amortizacija), vežimèliai ir ritinèliai (iššokę ir laisvai besisukantys ratų stebulių dangteliai, susidèvejję rutuliniai guoliai), elektros instaliacija (tinklas neturi saugiklių, kyla trumpojo jungimo ir gaisro pavojus). Technikos dirbtuvèse pagal galimybes buvo šalinami pastebèti trūkumai: taisomos arba keičiamos naujomis susidèvejusios dalys, tobulinama konstrukcija (dedami elektros instaliacijos saugikliai), teikiamos rekomendacijos tam tikrais tankų priežiūros klausimais ${ }^{41}$. Siekdamas taupyti VCL techninius resursus, Kariuomenès štabo I skyrius, organizuodamas pratybas 1938 m., ịsake šio modelio tankus naudoti tik visapusiškiems mokomiesiems pratimams atlikti ${ }^{42}$.

\footnotetext{
38 Ten pat, 1. 64-64 a. p.

39 Ten pat, 1. 64-64 a. p.

40 1938-05-09 2-os tankų kuopos tankus „V.C.L.“ remontuojant pastebèti trūkumai bei konstrukcijos netobulumai, LCVA, f. 828, ap. 1, b. 150, 1. 70-70 a. p.

41 Ten pat, 1. 70-70 a. p.

42 1938-02-11 įsakymas Gaižiūnų poligone $1938 \mathrm{~m}$. pratimams organizuoti, LCVA, f. 828 , ap. 1, b. $171,1.2$.
} 
Technikos dirbtuvėse atliktų remonto darbų rezultatai buvo matyti jau per 1938 m. rudens kariuomenés manevrus, kurių metu sugedo tik vienas 2-osios tankų kuopos VCL ${ }^{43}$. Dèl prastos kokybès tepalo sugedo variklis, teko tanką iš dalies išardyti ir sunkvežimiu išvežti. Kiti kuopos tankai veike normaliai, nors pasitaikè vienas kitas lengvas gedimas, bet jie buvo pašalinti vietoje: vieno tanko nutrūko vikšras (dèl vikšrų sąnario sudilimo), dar keli 2-osios tankų kuopos VCL gedo dèl variklių siurblių konstrukcijos defekto - nepakankamo degalų tiekimo ${ }^{44}$. Nepaisant šių santykinai nedidelių nesklandumų, matyti, kad 1938 m. rudenį, palyginti su gerokai sunkesne padètimi prieš metus, 2-osios tankų kuopos tankų „Vickers-Carden Loyd“ techniné būklè apskritai buvo gana gera, o pats padalinys - geriau pasirengęs atlikti galimas kovines užduotis.

Vis dèlto Šarvuočiu rinktinès technikos dirbtuvèms darbo netrūko ir vèliau. 1939 m. pradžioje kelių tankų VCL nebegalima buvo naudoti dèl perdèm susidèvejusių variklių ${ }^{45}$. Remiantis specialios tyrimų komisijos pastabomis, technikos dirbtuvèse jau tų pačiu metų balandžio mèn. buvo nutarta arba jau pradèta ịgyvendinti nemažai techninių sprendimų, susijusių su tankų variklių, kūginių pavarų, radiatorių, vežimèlių ir ritinèlių gedimais ${ }^{46}$. Gedimų tyrimų išvadose taip pat pabrèžta būtinybè naudoti tinkamos kokybès tepalą, deramai sutepti ir išvalyti tokias konstrukcijos detales kaip oro filtrai ar vežimèlių ašys ir apskritai rūpintis, kad ị jautrias vidines tanko variklio ir važiuoklès dalis nepatektų dulkių, smèlio ar purvo, dèl ko šios dalys greitai susidèvi ir genda ${ }^{47}$.

\footnotetext{
431938 m. kpt. Migevičiaus pastabos apie ịvykusius per š. m. kariuomenès manevrus autopriemonių ir tankų gedimus, LCVA, f. 828, ap. 1, b. 179, 1. 59.

44 Ten pat, 1. 59; 1938 m. rugsèjo mèn. Šarvuočių rinktinès kariuomenès manevrų metu kovos mašinų gedimų sąrašas, $L C V A$, f. 828, ap. 1, b. 179, 1. 52; 1938-09-20 raportas kuopos vadui, $L C V A$, f. 828 , ap. 1, b. 179, 1. 60 .

451939 kovo mèn. Tyrimų komisijos posėdžio protokolas Nr. 58, LCVA, f. 828, ap. 1, b. $151,1.23-23$ a. p.

46 1939-04-12 protokolas Nr. 73, LCVA, f. 828, ap. 1, b. 151, 1. 24-24 a. p.

47 Ten pat, 1. 24; 1939 kovo mèn. Tyrimų komisijos posėdžio protokolas Nr. 58, LCVA, f. 828, ap. 1, b. 151, 1. 23 a. p.; 1939-04-13 Šarvuočių rinktinès Technikos skyriaus pastabos dèl remontuojamų 2-osios tankų kuopos tankų problemų ir nurodymai joms pašalinti, LCVA, f. 828, ap. 1, b. 151, 1. 69.
} 


\subsection{5 m. modelio lengvasis tankas „Vickers-Carden Loyd“}

Netrukus po to, kai Šarvuočių rinktinejje buvo suformuota 2-oji tankų kuopa, Lietuvos kariuomenè $1935 \mathrm{~m}$. antrojoje pusèje pradejo nauju lengvųjų tankų paieškas. 1935 m. rugsèjo $11 \mathrm{~d}$. šių kovos mašinų pirkimo klausimą nagrinèjo karo technikos viršininko nurodymu sudaryta komisija: Karo technikos tiekimo skyriaus plk. ltn. Petras Masiulis (pirmininkas), Šarvuočių rinktinès mjr. Jonas Kondratas ir 1-ojo husarų pulko ltn. Stasys Kuzmickas $^{48}$. Iš keliolikos firmų ir privačių asmenų, kuriems kariuomenè pateikè paklausimus dèl lengvųjų tankų pirkimo pasiūlymų, savo variantus pateikẻ keturios užsienio kompanijos: prancūzų „Renault“, švedų „Landsverk“, britų „Vickers“ ir „Straussler“49. Išnagrinejjus pateiktus pasiūlymus, nepalankiausiai ịvertinta buvo prancūzų „Renault ZB“ tanketè, kuri pasirodè esanti per maža, nemodernios konstrukcijos ir, palyginti su „Vickers“ gaminiu, prieš kurị neturẻjo jokių pranašumų, per brangi. Komisijos manymu, visus techninius reikalavimus ir kariuomenès poreikius atitiko švedų gamybos lengvasis tankas „Landsverk 100“, pasižymintis modernesne už konkurentų konstrukcija ir solidžia ginkluote (galëjo būti apginkluotas automatiniu pabūklu). Kompanijos „Vickers“ pasiūlymas išsiskyrè pačia patraukliausia kaina: britų siūlomas tankas su ginkluote kainavo 81960 Lt, o „Landsverk 100“ - 127000 Lt be ginkluotès ${ }^{50}$. „Vickers“ lengvojo tanko didžiausias greitis buvo $10 \mathrm{~km} / \mathrm{val}$. didesnis už švediškojo modelio, tačiau, komisijos manymu, tai nèra taip svarbu, kaip greitis nelygia, raižyta vietove, kur „Landsverk 100“ galimai būtų turèjęs pranašumą dèl modernesnès pakabos sistemos, tačiau tai galejo parodyti tik lauko bandymai. Be to, pažymėta, kad „Vickers“ kovos mašina nusileido švedų konkurentui konstrukcinių sprendimų modernumu ir joje negali būti tinkamai ịtaisytas automatinis pabūklas ${ }^{51}$.

Be minètų kovos mašinų, buvo svarstomi kompanijų „Vickers“, „Landsverk“ ir „Straussler“ Lietuvos kariuomenei pateikti sunkesnių, 7 t, lengvụjų tankų pirkimo pasiūlymai. Ši kartą dèl nemodernios konstrukcijos, mažo greičio ir variklio galingumo prasčiausiai ịvertintas buvo

\footnotetext{
48 1935-10-10 aktas Nr. 121, LCVA, f. 1364, ap. 3, b. 205, 1. 9.

49 Ten pat, 1. 9.

50 Ten pat, 1. 9.

51 Ten pat, 1. 9 .
} 
„Vickers" siūlomas lengvojo tanko modelis. Komisijos manymu, švedų gamintojo šioje tankų kategorijoje pasiūlytas „Landsverk 60“ su dvigubai galingesniu varikliu už pastarąji buvo kur kas geresnis ${ }^{52}$. Vis dèlto didžiausią susidoméjimą, nors ir nežinant visų duomenų, sukèlè britų įmonés „Straussler“ siūlomas novatoriškos konstrukcijos tankas. Pagrindinè jo skiriamoji ypatybè buvo ta, kad jis galëjo vienodai gerai veikti ir kaip tankas, ir, nuėmus vikšrus (nuimti ar uždèti vikšrus užtrukdavo 8-12 min.), kaip ratinis šarvuotis. Ši kovos mašina, kurios kaina be ginkluotès sieke 165000 Lt, taip pat išsiskyrè dideliu greičiu (didžiausias greitis su vikšrais $-60 \mathrm{~km} /$ val., o be vikšrų $-85 \mathrm{~km} / \mathrm{val}$.), savitais važiuoklès ir pakabos konstrukciniais sprendimais ir, komisijos manymu, turëjo svarbių pranašumų prieš konkurentus tiek kaip tankas, tiek kaip ratinis šarvuotis. Vis delto, nors ir susidariusi, regis, gerą nuomonę apie „Straussler" tanką, komisija pabrèžè, kad būtina nuodugniau ištirti ir išbandyti siūlomus mašinų variantus, ir susilaikè nuo konkrečių pirkimo rekomendacijų ${ }^{53}$.

Karo technikos viršininkas savo $1935 \mathrm{~m}$. spalio $24 \mathrm{~d}$. raporte kariuomenès vadui pristate šios komisijos svarstymus ir pranešè pritariantis jos nuomonei, kad, prieš perkant naują šarvuotąją techniką, reikia sudaryti naują specialią komisiją, kuri turètų vykti pas pasirinktus užsienio gamintojus ir ten apžiūrèti bei išbandyti jų siūlomas kovos mašinas ${ }^{54}$. Iš šio raporto taip pat sužinome, kad Krašto apsaugos ministerijos 1936-1937 m. nepaprastųjų išlaidų sąmatoje buvo numatyta $2680000 \mathrm{Lt}$, už kuriuos planuota ịsigyti 16 lengvụjų tankų (tankečių) ir 6 šarvuotuosius automobilius (šarvuočius). Vis dèlto, išnagrinèjus gautus pasiūlymus, paaiškejjo, kad šios sumos būtų nepakakę visiems planuojamiems naujos šarvuotosios technikos vienetams ịsigyti, todèl prieš siunčiant pas gamintojus vertinimo komisiją kariuomenès vado brg. gen. Stasio Raštikio buvo prašoma išspręsti klausimus, susijusius su tuo, kokių tiksliai šarvuotujjų kovos mašinų reikia Lietuvos kariuomenès poreikiams patenkinti ${ }^{55}$. Po ménesio karo technikos viršininkui skirtame pranešime kariuomenès vadas nurodè vykdyti minètais klausimais valstybės karo tarybos priimtus nutarimus - atsisakyti šarvuotųjų automobilių pirkimo

\footnotetext{
52 Ten pat, 1. 9.

53 Ten pat, 1. 9-9 a. p.

54 1935-10-24 raportas kariuomenès vadui, $L C V A$, f. 1364, ap. 3, b. 205, 111.

55 Ten pat, 1. 11.
} 
ir ypatingą dėmesį skirti dar vienai tankečių kuopai (maždaug 4 t svorio lengvieji tankai) ir vienai lengvųjų tankų kuopai (maždaug 7 t svorio kovos mašinos) reikalingos karo technikos įsigijimui ${ }^{56}$.

Remdamasi šiuo nutarimu, komisija, pirmininkaujama Karo technikos tiekimo skyriaus viršininko plk. ltn. K. Jonūno, kartu su to paties skyriaus plk. ltn. P. Masiuliu ir Šarvuočių rinktinès mjr. J. Kondratu iš naujo peržiūrèjo pateiktus lengvųjų tankų pasiūlymus ${ }^{57}$. Mažiausiojo svorio tankų (tankečių) kategorijoje ir vèl buvo išskirti kompanijų „Vickers Armstrongs" ir "Landsverk" gaminiai. Pastarasis modelis, sprendžiant iš jo aprašymų, komisijos manymu, pasirodè esąs modernesnis ir kone visais atžvilgiais atitinkantis kariuomenès reikalavimus. Vis dèlto švedų i̇monès siūlomos kovos mašinos dar nebuvo nei apžiūrètos, nei išbandytos, todèl komisija siūlè (jei pirkimo klausimą reikètų spręsti disponuojant tik gamintojų pateiktais duomenimis ir aprašymais) rinktis kaip mažiau rizikingą kompanijos „Vickers“ tanketès modelį. Toks siūlymas buvo motyvuojamas tuo, kad „Vickers“ tanketè jau buvo naudojama Lietuvos kariuomenejje, todèl gerai pažįstama ir išbandyta, o britụ firmos siūlomas naujesnis modelis nuo naudojamo kariuomenejje skyrèsi tik nauja pakabos sistema ir galingesniu varikliu, dèl ko turejo gebèti pasiekti didesni greitị važiuodamas nelygia vietove. Tačiau jo ginkluotès galimybès liko ribotos, kadangi, komisijos manymu, „Vickers“ kovos mašinoje nebuvo įmanoma ịtaisyti „Oerlikon" automatinio pabūklo ${ }^{58}$. Iš Lietuvos kariuomenei siūlomų $7 \mathrm{t}$ svorio lengvųjų tankų komisija teigè negalinti rekomenduoti įsigyti kurio nors varianto, kadangi dominančias kovos mašinas (remiantis aprašymais, moderniausi ir atitinkantys reikalavimus buvo firmų „Straussler Mecanization“ ir „Landsverk“ lengvieji tankai) dar reikètų nuodugniai apžiūrèti ir išbandyti ${ }^{59}$.

Naujųjų Lietuvos kariuomenès lengvųjų tankų iki 4 t konkurso favoritas ir su tuo susijusios priežastys ịvardytos $1936 \mathrm{~m}$. kovo $5 \mathrm{~d}$. karo technikos viršininko rašte kariuomenès tiekimo viršininkui ${ }^{60}$. Iš šio do-

\footnotetext{
56 1935-11-28 pranešimas karo technikos viršininkui, LCVA, f. 1364, ap. 3, b. 205, 1. 12.

57 1935-12-27 aktas Nr. 158, LCVA, f. 1364, ap. 3, b. 205, 1. 14-14 a. p.

58 Ten pat, 1. 14.

59 Ten pat, 1. 14 a. p.

60 1936-03-05 raštas kariuomenès tiekimo viršininkui, $L C V A$, f. 1364 , ap. 3, b. 205, 1. 21-21 a. p.
} 
kumento matome, kad $1935 \mathrm{~m}$. liepos 13 d. skelbiant naujų šarvuotujų kovos mašinų pirkimo konkursą, be kita ko, buvo siekiama įsigyti dvylika tankečių, ginkluotų „Oerlikon“ $20 \mathrm{~mm}$ automatiniais pabūklais, ir 4 tokio pat modelio kovos mašinas, ginkluotas sunkiaisiais kulkosvaidžiais ${ }^{61}$. Igyvendinusi šs planą, Lietuvos kariuomené pirmą kartą ỉsigytų karinès technikos, kuri būtų palyginti greita ir manevringa važiuodama nelygia vietove, turètų patikimą šarvinę apsaugą ir ginkluotę, kuria galima efektyviai naikinti priešo šarvuotają techniką. Deja, aptariamojo naujos karinès technikos pirkimo konkurso metu nè vienas gamintojas, atsiuntęs savo pasiūlymus dèl lengvụjų tankų iki $4 \mathrm{t}$ svorio gamybos, negalèjo pademonstruoti savo gaminio su jau ịrengta tokio tipo ginkluote, t. $y$. automatiniu pabūklu ${ }^{62}$. Tokiu būdu tai, kad Lietuvos kariuomenei priklausantys „Vickers“ lengvieji tankai pasirodè esantys tinkami vykdyti toms užduotims, kurioms jie buvo numatyti, taip pat pageidavimas kariuomenę aprūpinti vieno tipo ir vienos firmos gamybos tanketemis ir tai, kad konkurentai negalèjo pasiūlyti kovos mašinų su pranašesne ginkluote, lėmé, kad karo technikos viršininkas aptariamajame rašte paprašè kariuomenès tiekimo viršininko leisti pirkti firmos „Vickers" siūlomus $4 \mathrm{t}$ lengvuosius tankus. Šešiolika šių kovos mašinų, ginkluotų „Vickers“ sistemos kulkosvaidžiais, iš viso turëjo kainuoti 43712 svarų (vienas tankas - 2732 svarus), arba pagal tuometị valiutos kursą - $1311360 \mathrm{Lt}^{63}$. Palyginti su anksčiau ịsigytais tos pačios britu firmos lengvaisiais tankais, naujieji turëjo pasiekti didesnị maksimalų greiți, turèti galingesnį variklị, storesnius šarvus, naują pakabos sistemą ir kainuoti 285 svarais (vienetas) daugiau. O nuo $7 \mathrm{t}$ svorio lengvujjų tankų i̇sigijimo rekomenduota laikinai susilaikyti ir ị mènesio trukmès komandiruotę $\mathfrak{i}$ Čekoslovakiją, Prancūziją, Didžiąją Britaniją ir Švediją pasiųsti specialią komisiją apžiūrèti vietos gamintojų siūlomų kovos mašin $u^{64}$.

1936 m. balandžio 27 d. karo technikos viršininkas praneše kariuomenès tiekimo viršininkui, kad, Valstybės karo tarybai nutarus pirkti "Vickers" lengvưjų tankų, su britų firmos igaliotiniu galutinai susitarta dèl komercinių ir techninių sutarties sąlygų. Pagal šios sutarties projektą,

\footnotetext{
61 Ten pat, 1. 21.

62 Ten pat, 1. 21.

63 Ten pat, 1. 21-21 a. p.

64 Ten pat, 1. 21 a. p.
} 
Lietuva už šešiolika lengvụjų tankų (kiekvienas iš jų turèjo kainuoti apie 82000 Lt) su atsarginèmis dalimis jiems ir kulkosvaidžiams, amuniciją ir visų jų transportavimą turèjo sumokèti kiek daugiau nei 47 tūkst. svarų, arba 1420000 Lt $^{65}$. Jau kitą dieną krašto apsaugos ministras plk. Stasys Dirmantas paprašè ministro pirmininko ịtraukti pirkimo klausimą ¿̇ Ministrų Kabineto darbotvarkę ir leisti patvirtinti sutartị su „Vickers Armstrongs Ltd. “66. Beje, 1936 m. gegužès pradžioje Karo technikos tiekimo skyriaus atstovas plk. ltn. P. Masiulis, apsilankęs užsienio šarvuotosios technikos gamintojų firmose, savo raporte iš Londono, be kita ko, pranešè gavęs bandymais patvirtintų duomenų, kurie rodo, kad firmos „Vickers" gaminamos šarvų plokštelès kokybe pastebimai nusileidžia, pvz., čekų ar švedų gamintojų produkcijai ${ }^{67}$. Be to, jis teigé gavęs firmos „Vickers“ patikinimus, kad, laiku pateikus atitinkamą prašymą, galima šiek tiek pakeisti Lietuvos užsakymą ir vietoj jau užsakytų ir paruoštų gaminti lengvųjų tankų ịsigyti patobulintos konstrukcijos, didesnių gabaritų ir svorio $(5 \mathrm{t})$, turinčio erdvesnę kovinę patalpą tanko modelį, labiau pritaikytą sunkesnei ginkluotei, arba bent dalị užsakytụjų kovos mašinų perginkluoti „Vickers“ sistemos $40 \mathrm{~mm}$ pusiau automatiniais pabūklais.

Plk. ltn. P. Masiulis gavo progą apžiūrèti pastarąji modeli - tanką, ginkluotą $40 \mathrm{~mm}$ pabūklu, per minutę galinčiu iššauti apie 20 sviedinių, kurių pradinis greitis siektų $800 \mathrm{~m} / \mathrm{s}$, tačiau stokojančiu vietos radijo aparatui. Būtent tokio modelio tankus iš firmos „Vickers“ buvo įsigijusi ir Latvijos kariuomenè. Tiesa, dèl galimų Lietuvos pateikto užsakymo ir norimų ịsigyti lengvųjų tankų modelių pakeitimų būtų padidejjusi bendra užsakymo kaina ir pailgètu pristatymo terminai ${ }^{68}$. Ko gero, galima daryti prielaidą, kad būtent ši aplinkybė ir planai netolimoje ateityje ịsigyti sunkesnių, geriau šarvuotų ir ginkluotų lengvụjų tankų lèmé, jog 1936 m. gegužès 2 d. ịformintas pirminis užsakymas dèl šešiolikos „Vickers" kovos mašinų pirkimo nebuvo pakeistas ${ }^{69}$.

\footnotetext{
65 1936-04-27 pranešimas kariuomenès tiekimo viršininkui, $L C V A$, f. 1364, ap. 3, b. 205 , 1. 26; 1936-04-28 raštas ponui ministeriui pirmininkui, $L C V A$, f. 1364, ap. 3, b. 205, 1. 27. 66 1936-04-28 raštas ponui ministeriui pirmininkui, $L C V A$, f. 1364, ap. 3, b. 205, 1. 27.

67 1936-05-08 raportas Karo technikos tiekimo skyriaus viršininkui, LCVA, f. 1364, ap. 3, b. $205,1.28$.

68 Ten pat, 1. 28-28 a. p.

69 V. Grigoraitis, Lietuvos kariuomenès technika 1918-1940 m., p. 113-114.
} 
Tokiu būdu Lietuvos kariuomenę papildè šešiolika 1935 m. modelio lengvujų tankų „Vickers-Carden Loyd“ ir buvo sukomplektuota Šarvuočių rinktinès 3-ioji tankų kuopa ${ }^{70}$. Naujosios kovos mašinos svèrè $4 \mathrm{t}$, jų aukštis siekè $193 \mathrm{~cm}$, plotis $-190 \mathrm{~cm}$, ilgis $-355 \mathrm{~cm}$, prošvaisa $-32,7 \mathrm{~cm}$. Jie turèjo galingesnị nei ankstesnio VCL modelio 6 cilindrų, 80 AG benzininị variklį ir galejo pasiekti didžiausią $60 \mathrm{~km} / \mathrm{val}$. greitị. Nuo savo pirmtakų naujieji „Vickers“ tankai, kurių igulą turejjo sudaryti 2 žmonès (vairuotojas ir tanko vadas), ginkluoti vienu sunkiuoju „Vickers“ sistemos kulkosvaidžiu, taip pat skyrèsi kitokia važiuoklès pakabos sistema, bokštelio forma, storesniais šarvais ir stebejimo angų apsauga iš neperšaunamo stiklo. 1936 m. gruodi naujosioms kovos mašinoms buvo užsakytos radijo stotys $^{71}$.

Apie naujųjų Lietuvos kariuomenès lengvųjų tankų galimybes važiuoti raižyta vietove įdomių žinių gauta per $1937 \mathrm{~m}$. kovo $6 \mathrm{~d}$. bandomuosius važiavimus ${ }^{72}$. Atliekant bandymus paaiškejjo, kad VCL suartą lauką ir pievą, lygų lauką ir $30^{\circ}$ statumo ịkalnę, padengtus atitinkamai 10, 30 ir $35 \mathrm{~cm}$ sniego danga, gali ịveikti važiuodamas $2-3$ pavara (ịkalnè ịveikta tik iki galo nuspaudus akceleratoriaus pedalą). $30-35 \mathrm{~cm}$ sniego sluoksniu padengto $30^{\circ}$ statumo šlaito tankas nepajège íveikti tik tuomet, kai jo viršuje po sniego danga pasiekė apledejusią žemę ir pradejjo buksuoti, o $40^{\circ}$ statumo ikkalné, padengta $20-25 \mathrm{~cm}$ storio sniego danga, apskritai pasirodè esanti per sunki užduotis. Sunkumų tankui sukèlè ir kelios duobès, iš kurių pirmoji buvo pailgos formos, apaugusi krūmais, 40-50 statumo šlaitais ir padengta $90 \mathrm{~cm}$ storio sniego danga, antroji $-140 \mathrm{~cm}$ gylio, visiškai užnešta sniegu, ir maždaug $50-60^{\circ}$ statumo šlaitais. Abiem atvejais kliūties neịveikusị VCL teko traukti iš duobès kitai mašinai. Su nepatogumais buvo susidurta ir važiuojant rogių pravažinètu, tačiau vietomis šonuose $20-30 \mathrm{~cm}$ storio sniego sluoksniu padengtu siauru lauko keliu, kadangi dèl nepakankamai plačių rogių vẻžių tanko vikšrai vienu metu važiavo skirtingais paviršiais (rogių vèžèmis ir puriu sniegu) ir dèl

\footnotetext{
70 Ten pat, p. 114-115.

711940 balandžio mèn. Lietuvos kariuomenès tankų duomenys, LCVA, f. 828, ap. 1,

b. 141, 1. 1; V. Grigoraitis, Lietuvos kariuomenes technika 1918-1940 m., p. 114-115;

A. Pociūnas, A. Stoliarovas, min. veik., p. 20.

72 1937-03-12 važiavimo lengvuoju tanku „Vickers-Carden Loyd“ 1937 m. kovo 6 d. duomenys, $L C V A$, f. 828 , ap. 1, b. 131, 1. 31 .
} 
to slydo į griovius. Nepaisant to, šia vietove tankas, nors ir sunkiai, galèjo važiuoti 2 pavara, o rogèmis pravažinètu, nors vietomis ir užpustytu, vieškeliu Radviliškis-Šiauliai - 3-4 pavara $^{73}$. Tačiau vis dèlto, remiantis praktika, paaiškejo, kad tankams „Vickers-Carden Loyd“ stora sniego danga (daugiau kaip 20-30 cm) buvo rimta kliūtis, smarkiai ribojusi ju manevringumą, kadangi vertė važiuoti keliais, ir dèl grèsmès ịklimpti didesnèse pusnyse beveik neleidusi nuo jų nuvažiuoti $\mathfrak{i}$ atvirą lauką ${ }^{74}$.

Per 1938 m. rudens kariuomenès manevrus aikštèn iškilo keletas 3-iosios tankų kuopos kovos mašinų techninių nesklandumų, kurie, tiesa, nebuvo labai rimti. Daugelyje kuopos tankų bildejo vožtuvai, iš karterio ir ratų tekèjo dèl ịkaitimo suskystėjęs tepalas. Be to, trūko vieno iš šių tankų vikšrai (dèl vikšro sąnario susidèvejimo), kito - važiuoklès užpakalinèje spyruoklèje buvo pastebètas ịtrūkimas, o dar vieno naktinio žygio metu dèl atsilaisvinusių laikiklių iškrito gesintuvas ${ }^{75}$. Kadangi tiek anksčiau Lietuvos kariuomenès įsigytieji VCL tankai, tiek naujieji jų modeliai, ịtraukti atitinkamai ị 2-osios ir 3-iosios tankų kuopų sudètị, buvo beveik tapatūs, jiems galiojo ir tos pačios technikos priežiūros taisyklès ir reikalavimai ${ }^{76}$. Vis dèlto atliekant bandymus Šarvuočių rinktinèje pastebèta naujųjų „Vickers“ kovos mašinų vikšrų tendencija kristi nuo varomųjų ratų. Šiuo klausimu susisiekus su gamintojo firma, sužinota, kad šis trūkumas išryškejja tik važiuojant pirmuosius $150 \mathrm{~km}$, iki to laiko firma patarè važinèti kiek labiau nei ịprastai ịtemptais vikšrais, mažesniu greičiu, o važiuojant greičiau - nedaryti staigių posūkių ${ }^{77}$.

Visi šie techniniai nesklandumai, nors ir kẻlè nepatogumų, nebuvo tokie rimti, kad galètų esmingai pakenkti kovos padalinio pasirengimui.

\footnotetext{
73 Ten pat, 1. 31 .

74 1938-01-14 Karo technikos viršininko Šarvuočių rinktinès parengties dalinių patikra 1938-01-07, LCVA, f. 828, ap. 1, b. 159, 1. 8.

751938 m. rugsejjo mèn. Šarvuočių rinktinès kariuomenès manevrų metu kovos mašinų gedimų sąrašas, $L C V A$, f. 828, ap. 1, b. 179, 1. 52; 1938-09-20 Šarvuočių rinktinès 3-iosios tankų kuopos mašinose rastų trūkumų po kariuomenès manevrų sąrašas, $L C V A$, f. 828, ap. 1, b. 179, 1. 55 .

76 1939-04-13 Šarvuočių rinktinès Technikos skyriaus pastabos dèl remontuojamuose 2-osios tankų kuopos tankuose pastebėtų problemų ir nurodymai joms pašalinti, LCVA, f. 828 , ap. 1, b. $151,1.69$.

77 1939-05-20 Karo technikos tiekimo skyriaus Technikos dalies pranešimas Šarvuočiu rinktinès vadui, $L C V A$, f. 828, ap. 1, b. 151, 1. 70.
} 
Tai galime matyti ir iš 1939 m. birželio mèn. Šarvuočių rinktinès pasirengimo paskelbus pavojaus būklę duomenų suvestinès ${ }^{78}$. Šiame dokumente nurodoma, kad minètu atveju iš rinktinès parengties daliniui priklausiusios 3-iosios tankų kuopos per 3 valandas, kai buvo gautas įsakymas, vykdyti skirtų užduočių iš nuolatinès dislokacijos vietos turèjo išvykti 3 tankų būriai (kiekvienas po penkis tankus). O 1-oji ir 2-oji tankų kuopos, taip pat viena 3-iosios kuopos kovos mašina (iš viso 12 „Renault FT 17“ ir 17 VCL) turèjo pasilikti rinktinès tarnybai ir mobilizacijai vykdyti ${ }^{79}$. Tiesa, 3-ioji tankų kuopa, o kartu ir visa Šarvuočių rinktinė patyrė skaudụ smūgị dèl gaisro, kilusio dèl nelaimingo atsitikimo kuopos garažuose Vilniuje 1939 m. lapkričio 7 d. Gaisras, padaręs žalos už maždaug 800 tūkst. Lt, sunaikino septynis ir apgadino tris 3-iosios tankų kuopos VCL, taip pat nemažai kitos technikos. O dèl atsarginių dalių trūkumo, nesant galimybès grąžinti ị rikiuotę bent dalies nukentejjusių kovos mašinų, naujausiais ir techniškai bene tvarkingiausiais tankais apginkluota Šarvuočių rinktinès kuopa neteko beveik pusès savo šarvuotosios karo technikos ${ }^{80}$.

\subsection{Tankų padalinių karių mokymo problemos}

Tankų padalinių koviniam pajègumui ir galimybei sèkmingai vykdyti kovos užduotis, be pačių kovos mašinų techninių savybių ir būklès, be abejo, itin didelę reikšmę turèjo karių, personalo pasirengimo ir mokymo kokybè. 1932 m. rugsèji Šarvuočių rinktinès inspekcinę apžiūrą atlikęs tuometis karo technikos viršininkas plk. Klemensas Popeliučka atkreipè dèmesi, kad dalies eilinių karių, priešingai nei puskarininkių, specialybės žinios yra menkos: jie prastai išmanè kulkosvaidžių ir vidaus degimo variklių veikimo principus ir sandarą (bet daugumos jų bendrosios ir statutų žinios įvertintos kaip pakankamos) $)^{81}$.

Aptariamuoju aspektu daug sužinome iš jau minèto $1934 \mathrm{~m}$. kovo mèn. tuo metu vienintelès Lietuvos kariuomenejje tankų kuopos vado pla-

78 1939-06-21 Žinios apie Šarvuočių rinktinès pasirengimą skelbiant pavojaus būklę, LCVA, f. 828, ap. 1, b. 197, lapai nenumeruoti.

79 Ten pat, lapai nenumeruoti.

80 A. Pociūnas, A. Stoliarovas, Tankai Lietuvos kariuomeneje 1924-1940 m., p. 21.

81 1932-09-13 aro technikos viršininko įsakymas Nr. 5, LCVA, f. 828, ap. 1, b. 155, 1. 77. 
taus raporto Šarvuočių rinktinès vadui ${ }^{82}$. Dokumente nuosekliai išdèstytos visos tuo metu padalini kamavusios problemos, susijusios tiek su technika, tiek su žmonėmis ar patalpomis. Pirmiausia atkreipiamas dėmesys ì mažą, palyginti su visu sąrašu, karių, galëjusių dalyvauti mokymuose ir kituose užsièmimuose, skaičių. Tai lèmè būtinybe išskirstyti daugumą karių i ịvairias rinktinès ar kuopos tarnybas, neturinčias etatinio personalo. Tankų kuopos vado pateiktame sąraše matome, kad $1934 \mathrm{~m}$. kovo $12 \mathrm{~d}$. iš 87 žmonių 16 puskarininkių ir eilinių buvo komandiruoti dirbti ịvairių darbų (ūkio skyriaus raštininko, rinktinès ūkvedžio, krautuvininko, ūkio skyriaus vežiko ir t. t.) ł rinktinès štabą, 4 žmonès paskirti ị rinktinès dirbtuves (dirbti šaltkalviu, kalviu, staliais), 7 kuopos nariai (kuopos viršila, raštininkas, ùkvedys, maistininkas, batsiuvys ir virèjai) užsiemmimuose dalyvauti negalejo, 12-18 karių èjo ịvairias pareigas kuopoje (budètojo, patrulių, sargybinių ir t. t.), 8 žmonès, daugiausia naujokai, komandiruoti mokytis $\mathfrak{i}$ kitus padalinius, dèl sveikatos iš rikiuotès buvo „iškritę" 8-9 kariai. Taigi, mokymuose dèl vienų ar kitų priežasčių dalyvauti negalèjo mažiausiai 55 kuopos kariai. Negana to, tų pačių metų balandžio mėnesị, išleidus i atsargą 27 karius, jų pareigas turejo perimti naujokai, kurie dèl to nebūtų mokomi svarbiausių specialybės dalykų, kaip numatyta mokymo plane. Todèl kuopos vadas prašè, kad rinktinès štabe, ūkio skyriuje ir dirbtuvèse dirbantys žmonès būtų išskirti $\mathfrak{i}$ atskirą etatinę grupę ir tik naujokams apmokyti galètų būti priskirti tankų kuopai ${ }^{83}$.

Rūpesčių taip pat kèlè ir padalinio naujokai, kurių, be kita ko, buvo per mažai, pirmiausia - jų išsilavinimas. Iš atvykusių naujokų 25 žmones reikèjo skirti ị mokomąsias dalis, kuriose buvo rengiami puskarininkiai ir ivvairūs specialistai, todèl, kuopos vado nuomone, $\mathfrak{i}$ tankų padalinị turejo būti siunčiami naujokai, baigę bent pradinę mokyklą ${ }^{84}$ Naujokų sveikata taip pat buvo prasta. Kuopos vado pateiktais duomenimis, iš $1933 \mathrm{~m}$. gegužès mèn. šaukimo 25 naujokų i naujokų rezervą buvo perkelti 7 , o iš tų pačių metų lapkričio mèn. šauktinių, kurių atvyko 31, nuo tarnybos atleisti 6 žmonès $s^{85}$. Kaip tam tikras trūkumas ịvardyta ir tai, kad tankų kuopos kulkosvaidininkams nebuvo leidžiama dalyvauti poligone vykusiose

\footnotetext{
82 193403-12 raportas rinktinès vadui, $L C V A$, f. 828 , ap. 1, b. 74, 1. 25-27.

83 Ten pat, 1. 25-26.

84 Ten pat, 1. 26.

85 Ten pat, 1. 26.
} 
„prizinio“ šaudymo iš sunkiųjų kulkosvaidžių varžybose, nors jų šaudymo mokymo programa ir pratimai beveik nesiskyrè nuo rengiamų pėstininkų ir kavalerijos sunkiųjų kulkosvaidžių padaliniams. Todèl, norint paskatinti kuopos karius pagerinti savo šaudymo rezultatus, siūlyta keisti padètį ${ }^{86}$.

Kaip jau minèta, šiuo laikotarpiu tankų kuopos „Renault FT 17“ ir sunkieji kulkosvaidžiai buvo labai prastos būklès. Tam turejo įtakos ir netinkami tokiam brangiam turtui laikyti garažai: kovos mašinoms, ginklams ir amunicijai kenkè besikaupianti drègmè, o žiemą dirbti dar ir nešildomose patalpose buvo labai sunku. Be to, nei garažuose, nei atokiau nuo jų stovinčiose kuopos kareivinèse (toks patalpų atskyrimas, kuopos vado manymu, buvo nepageidautinas ir net pavojingas) nebuvo priešgaisrinių priemonių ${ }^{87}$. Panaši informacija apie rinktinès infrastruktūros būklę pateikta ir 1934 m. rugsẻjo mèn. tuometinio Šarvuočių rinktinès vado plk. ltn. Zigmo Talevičiaus raporte karo technikos viršininkui. Jame bene daugiausia kritikos sulaukẻ būtent tankų padalinys. Atkreiptas dèmesys dèl nepraktiškumo ir nepakankamo saugumo ị didelị atstumą $(500 \mathrm{~m})$, skiriantị kareivines nuo garažų, apleistą, netvarkingą kuopos dislokacijos rajoną (ko gero, laikant ji laikinu), butų karininkams ir puskarininkiams trūkumą, per ankštas sandèlių patalpas, visiškai netinkamas ilgalaikiam arklių laikymui arklides, tankams kenkiančius drègnus garažus ${ }^{88}$.

1935 m., siekiant patobulinti karių mokymo procesą, Šarvuočių rinktinèje buvo suformuotas mokomasis būrys ${ }^{89}$. Būtent šiam padaliniui buvo patikèta per 6 mèn. mokomąji kursą, baigiamą egzaminais, parengti tankų vadus ir vairuotojus, kurie iki tol buvo rengiami atskiruose rinktinès padaliniuose. I mokomąji būrị buvo atrenkami gabesni ir pagal sveikatos būklę tinkami kariai. Norintieji tapti tankų vadais turèjo, be kita ko, mokytis šarvuotųjų mašinų kovos taktikos, šaudybos, topografijos, išmanyti šios karo technikos ir jos ginkluotès konstrukciją. Tiesa, veiklos pradžioje mokomajam būriui labai stigo mokomųjų priemonių: mokant tankų igulas, trūko šių kovos mašinų modelių, brèžinių, vadovèlių ${ }^{90}$.

\footnotetext{
86 Ten pat, 1. 26 a. p.

87 Ten pat, 1. 27.

88 1934-09-21 raportas karo technikos viršininkui, LCVA, f. 828, ap. 1, b. 74, 1. 117-117 a. p.

89 Karo technikos dalių dvidešimtmetis 1919-1939, p. 204.

90 Ten pat, p. 203-204.
} 
1936 m. spalio mèn. 2-osios tankų kuopos vado kpt. N. Migevičiaus raporte Šarvuočių rinktinès vadui konstatuojama, kad karių pasirengimas ir išsilavinimas ir toliau kelia sunkumų ${ }^{91}$. Pirmiausia išskirtas per menkas eilinių karių teorinis pasirengimas valdyti tankus, turintis, kaip jau buvo minèta, neigiamą ittaką kovos mašinų eksploatacijai ir jų techninès būklès priežiūrai. Vadovaujantis kuopos karininkas netgi teigè, kad, jo manymu, nepagerinus teorinio mokymo kokybès, važinèti tankais derètų uždrausti, nes jie būtų tik gadinami. Pasak kpt. N. Migevičiaus, eiliniai kariai turi išmanyti tankų konstrukciją ir valdymą, kaip ir šautuvo dalių veikimą, todèl šiam tikslui juos mokant reikia naudoti atskirų tankų dalių pavyzdžius, brèžinius ir apskritai, prieš sodinant prie kovos mašinos vairo, iš pradžių nuodugniai su ja supažindinti. Taip pat atkreiptas dèmesys ị tai, kad dauguma eilinių karių vos moka rašyti ar skaityti arba net yra analfabetai (pasak kuopos vado, šiuo požiūriu geresni kariai tarnybos pradžioje atrenkami ił mokomuosius dalinius), žemès ūkio darbininkai, iki tol nesusidūrę su kovos mašinomis, todèl tinkamas jų parengimas valdyti tokią karo techniką kaip tankai dar svarbesnis ${ }^{92}$.

Atkreipus dèmesi $\mathfrak{i}$ mokymo kokybès spragas, buvo stengiamasi praturtinti Šarvuočių rinktinès mokomąji būrị trūkstamomis mokymo priemonėmis ${ }^{93}$. Kad kareiviai geriau susipažintų su tankų konstrukcija ir veikimo principais, buvo padaryti atitinkami brèžiniai, variklių ir kitų konstrukcijos dalių, taip pat jų detalių pavyzdžiai, modeliai, o mokyti vairuoti įrengtas tankodromas su ịvairiomis kliūtimis. Mokomajame būryje buvo supažindinama su įvairiomis ryšių priemonėmis, tankų radijo aparatais ir kaip jie veikia. Nagrinejjant ginkluotę ir mokant šaudybos taip pat buvo pasitelkiami brèžiniai ir pačių ginklų bei šaudmenų pavyzdžiai, specialūs treniruokliai. Stengiantis ịveikti mokomosios literatūros stygių, buvo paruošti ir išleisti konspektai apie atskiras tankų konstrukcijos dalis, ginkluotę, radijo ryšio priemones, tankų valdymo instrukcija ${ }^{94}$.

Taigi, kaip matome, Lietuvos kariuomenès šarvuotųjų padalinių, konkrečiai tankų, sudèties ir kovinio pajègumo plètra buvo ganètinai sunkus ir lètas procesas. Bene didžiausią ittaką tam darè riboti finansiniai ištek-

\footnotetext{
91 1936-10-21 raportas rinktinès vadui, $L C V A$, f. 828, ap. 1, b. 109, 1. 119-119 a. p.

92 Ten pat, 1. 119-119 a. p.

93 Karo technikos dalių dvidešimtmetis 1919-1939, p. 204.

94 Ten pat, p. 204-207.
} 
liai, atitekę krašto apsaugai, kurie neleido sparčiai plètoti šios brangios karo technikos rūšies pajėgų. Kariuomenè, atsižvelgdama ị turimas lèšas, buvo priversta atidžiai ịvertinti numatytų ịsigyti kovos mašinų kainos ir kokybès santykị ir vengti rizikingų, nors ir perspektyvių, neišbandytų variantų. Vis dèlto svarbiausia, ko gero, buvo tai, kad aptariamuoju laikotarpiu Lietuvos kariuomenès pasirinktų ịsigyti tankų modelių techninès galimybès leido jiems vykdyti numatytas užduotis.

Lengvųjų tankų naudojimo Lietuvos kariuomenejje istorija aiškiai rodo, kad jais apginkluotų padalinių koviniam pajègumui ir parengčiai ne mažesnę įtaką nei pačių kovos mašinų techninès savybès ir skaičius turèjo jų techninè būklè ir galimybès palaikyti tinkamą priežiūros kokybę. Neišvengiamai gendančios technikos remontas buvo brangus, sudetingas ir ilgai trunkantis procesas, bet jis vis dèlto buvo būtinas norint, kad tankų kuopos išlaikytų realią kovinę vertę pavojaus atveju. Atskira problema buvo minètuose padaliniuose tarnavusių karių mokymo ir išsilavinimo trūkumai. Tankų kuopoms, kaip karo technikos koviniams junginiams, reikejjo daugiau tam tikrų specialistų ir išsilavinusių eilinių karių, taip pat atitinkamų mokomųjų priemonių. Nepaisant minètų problemų, vis dèlto, ypač nuo XX a. 4-ojo dešimtmečio vidurio, Lietuvos kariuomenejje, priklausomai nuo galimybių, buvo dedamos pastangos nuosekliai tobulinti ir plètoti šarvuotąsias pajègas, įsigyjant naujų, modernesnių priemonių, išlaikyti tinkamą jų kovinę parengtị, atliekant būtinus remonto darbus, gerinant karių mokymo kokybę.

\section{LIETUVOS KARIUOMENĖS TANKŲ KOVINIO PANAUDOJIMO TEORIJA IR PRAKTIKA}

\section{1. Šaudyba}

Anksčiau aptartieji Lietuvos kariuomenės lengvųjų tankų konstrukcijos duomenys, techninè būklè tarnybos metu ir tam tikri jų padalinių karių mokymo aspektai yra tik viena sudedamoji, nors ir turinti neabejotinai didelę reikšmę, šių kovos mašinų bendrojo kovinio pajėgumo dalis. Tankų galimybėms atlikti patikètas kovines užduotis ne menkesnę itaką turejo ir jų veikimo taktika. Šiuo aspektu svarbu ne tik tai, kaip ir kokioms užduotims vykdyti kariuomenè planavo juos panaudoti, bet ir 
kokios buvo praktinès galimybės, paaiškèdavusios mokymų metu, igyvendinti šiuos taktinius sprendimus, ir jų rezultatai. Vieną svarbiausių vaidmenų tankams vykdant kovines užduotis vaidino jų pagrindiné ginkluotè ir igulos gebëjimai tiksliai ją valdyti.

Kaip jau minèta, kiekvienas Lietuvos kariuomenès tankas buvo ginkluotas vienu bokštelyje ịtaisytu 7,92 mm kalibro sunkiuoju kulkosvaidžiu, kuriam priklausè maždaug 3000-4000 šovinių kovinis komplektas ${ }^{95}$. Šiame bokštelyje buvo tanko vado vieta, todèl, be vietovès žvalgymo, ryšių palaikymo ir kitų vadovavimo kovos mašinos veiksmams funkcijų, pagrindinè jo užduotis buvo taikinių aptikimas ir naikinimas kulkosvaidžio ugnimi ${ }^{96}$. Toks konstrukcinis ginkluotès vietos ir jos valdymo klausimo sprendimas buvo pritaikytas tiek „Renault", tiek VCL kovos mašinose. Taip pat galima pažymèti, kad nagrinėjamuoju laikotarpiu, t. y. $\mathrm{XX}$ a. 4-ajame dešimtmetyje, tik sunkiaisiais kulkosvaidžiais ginkluoti ir palyginti nedidelio svorio (iki $7 \mathrm{t}$ ) lengvieji tankai buvo neatsiejama daugelio Europos šaliụ (taip pat ir didžiųjų valstybių - Didžiosios Britanijos, Prancūzijos, Vokietijos, Italijos, Lenkijos) šarvuotụjų pajègų dalis, turéjusi numatytą vietą kovos lauke (pirmiausia - žvalgyboje ir teikiant tiesioginès ugnies paramą $)^{97}$. Vis dèlto sunkusis kulkosvaidis praktiškai neturẻjo galimybių efektyviai kovoti su priešo šarvuotąja technika, ypač jei pastaroji buvo ginkluota galingesne ginkluote. Lietuvos kariuomenès tanku pagrindiniais taikiniais turejo tapti šarvinès apsaugos neturintys priešo koviniai vienetai, pirmiausia pèstininkai ir jų sunkieji ginklai ${ }^{98}$.

Būtent tokioms kovinèms užduotims tankų igulos turèjo būti ruošiamos, pavyzdžiui, pagal $1932 \mathrm{~m}$. šaudymo pratimų Gaižiūnų poligone planą, patvirtintą poligono viršininko plk. Oskaro Urbono ir poligono štabo viršininko plk. Vinco Vitkausko99. Iš minètame plane smulkiai apibūdintų

\footnotetext{
95 A. Pociūnas, A. Stoliarovas, Tankai Lietuvos kariuomeneje 1924-1940 m., p. 32.

96 Ten pat, p. 15.

97 Gen. št. plk. ltn. Jankauskas, Tankai ir prieštankiniai ginklai Ispanijos kare, Kardas, Nr. 1, Kaunas, 1939, p. 8; J. ltn. Pečiūra, Kaip klasifikuoti tankus, Mūsų žinynas, Nr. 135, Kaunas, 1936, p. 567, 569-570; Ltn. Pečiūra, Šarvuočiai ir motorizuota kariuomenè, Karys, Nr. 13, Kaunas, 1938, p. 279-280; Ltn. Pečiūra, Šarvuočiai ir motorizuota kariuomenè, Karys, Nr. 14, Kaunas, 1938, p. 402-403.

98 Ltn. Pečiūra, Pažinkime tankus, Karys, Nr. 40, Kaunas, 1939, p. 1116.

991932 m. Šaudymo planas tankų komendantams, atliekantiems pratimus iš tankų, Gai-
} 
šešių pratimų keturi buvo skirti pavieniams tankams „Renault FT 17“, o du - šių tankų būriui. Visi pratimai buvo padalyti ị dvi dalis - į užduotis, atliekamas tankams stovint ir judant. Pavienių tankų iguloms buvo iškelta užduotis iš 100 ir $200 \mathrm{~m}$ atstumo atakuoti šešis taikinius, imituojančius priešo pėstininkų lengvojo kulkosvaidžio grandị. Nepriklausomai nuo atstumo, iš sustojusio tanko šaulio reikalaujama, skyrus tam tikslui 50 šovinių, pataikyti ị visus šešis taikinius. O judančio tanko šaulys, atliekantis ši pratimą ir turintis dvigubai daugiau (100) šovinių, turejjo pataikyti bent ị vieną taikini. Pažymėtina, kad šiuos šaudymo pratimus vienodomis sąlygomis turèjo atlikti abu igulos nariai ${ }^{100}$. Visam tankų būriui skirti pratimai buvo šiek tiek kitokie: skyrèsi taikinių pobūdis ir šaudymo atstumai. Taikiniai turèjo imituoti penkis sunkiųjų kulkosvaidžių lizdus ir prie kiekvieno jų esančius keturis priešo karius. Atliekantis pirmąj t pratimą tankų būrys, sustojęs 150 $\mathrm{m}$ atstumu, kiekvienam šauliui (atliekant tankų būrių pratimus šaudè tik tankų vadai) skyrus po 100 šovinių, turèjo „neutralizuoti“ 3 sunkiųjų kulkosvaidžių lizdus ir 15 karius imituojančių taikinių. Antrąj būrio pratimą atliekančio padalinio užduotis buvo judant iš $300 \mathrm{~m}$ atstumo ir kiekvienam šauliui turint po 200 šovinių apšaudyti ir „neutralizuoti“ bent vieną vaizduojamą sunkiojo kulkosvaidžio lizdą ir 5 menamus karius ${ }^{101}$.

Sudètingesnè šaudymo pratimų programa pateikta $1935 \mathrm{~m}$. vasarą sudarytame mokymų plane, skirtame tuo metu dar visai naujiems „VickersCarden Loyd" tankams ${ }^{102}$. Atliekantys pirmus du šios programos pratimus vietoje stovintys tankai turejo per ribotą laiką (30 ir $40 \mathrm{~s}$ ) trumpomis šūvių serijomis (iš viso užduočiai atlikti gavę 15 šovinių) apšaudyti ir kliudyti taikinius, esančius už $100 \mathrm{~m}$. Vienas iš šių pratimų turèjo būti atliktas šauliams mūvint dujokaukes. Kitų dviejų šaudymo uždavinių tikslas buvo išmokyti tankų igulas taikytis ir šaudyti tankui judant. Numatyti du šių užduočių atlikimo būdai. Veikiantys pirmuoju būdu tankai, judėdami 0-90 kampu taikinio atžvilgiu, šūviams atlikti (iš viso 20 šovinių) turẻjo daryti penkis trumpus, 8-10 s trukmès, sustojimus. Antruoju - tankai, disponuojantys 30 šovinių, turèjo apšaudyti taikinị nesustodami, tik su-

žiūnų poligone, LCVA, f. 828, ap. 1, b. 155, 1. 44.

100 Ten pat, 1. 44.

101 Ten pat, 1. 44.

102 1935-08-14 Šarvuočių rinktinès tankų-tankečių dalinių kulk. šaudymo programa, LCVA, f. 828, ap. 1, b. 151, 1. 12. 
mažindami greitị nuo $10-12 \mathrm{~km} /$ val. iki 4-6 km/val. Šios užduotys buvo atliekamos nuo 400 arba 300 iki $100 \mathrm{~m}$ atstumu. Atliekant visus minètus aptariamosios mokymo programos pratimus taikytasi i 6 krūtinès arba juosmens taikinius, išskleistus ị liniją. Iš šaulių reikalauta pataikyti bent i vieną ar du iš jų. Atliekančių penktąji kovinio šaudymo pratimą tankų taikinys buvo $150 \mathrm{~m}$ skersmens plote išdèstytos 3 taikinių grupès po 4-6 juosmens taikinius kiekvienoje. Norèdami, kaip reikalauta, kliudyti po vieną šių dviejų grupių taikinị, tankai turèjo 400-100 m atstumu, judèdami $15-20 \mathrm{~km} /$ val. greičiu ir $15-25^{\circ} \mathrm{kampu}$ ị abi puses nuo bendrosios judejjimo krypties, trumpam 6-7 kartus sustoti, kad tiksliai iššautų (tam turẻdami 30 šovinių).

Šeštasis šaudymo pratimas nuo pastarojo skyrèsi tik tuo, kad tankams, judantiems 0-90 kampu, kad pataikytų i $200 \mathrm{~m}$ skersmens plote išdèstytas 3 taikinių grupes, reikejjo ne sustoti, o sumažinti greitị iki 4-6 km/val. Tam tikslui jie turejo 40 šovinių. Paskutinis, septintasis, kovinio šaudymo pratimas buvo skirtas visam VCL tankų būriui išmokyti pulti taikini, vaizduojantị $300 \mathrm{~m}$ skersmens plote išdėstytą etatinès sudèties pėstininkų būrị su dviem sunkiųjų kulkosvaidžių lizdais. Kad ịvykdytų šią užduotị, tankų būrys turejjo pasidalyti ị du skyrius ir vienu metu pulti taikini iš priekio ir sparno $90^{\circ}$ kampu. Apšaudymas vyko 400-100 m atstumu, tankams sumažinus greiti nuo 15-20 iki 4-6 km/val., kiekvienam jų tam buvo skirti 75 šoviniai. Pagal užduoties ìvykdymo sąlygas, reikejjo pataikyti ị abu sunkiųjų kulkosvaidžių lizdus ir mažiausiai i 4 pèstininkų taikinius ${ }^{103}$.

Šie šaudymo pratimų planai rodo, kad tankų igulos buvo rengiamos, atsižvelgiant ị kovos aplinkybes, naikinti arba bent jau slopinti priešo taikinius, kurie pirmiausia kèlè grèsmę saviems péstininkams arba kavalerijai. Taip pat matome, kad šių kovos užduočių sudètingumas labai priklausė nuo to, ar tankai turèjo šaudyti sustoję, ar judėdami.

Apie tankų šaudymo pratimų sudètingumą $1938 \mathrm{~m}$. rugsẻjị, po pratybų Gaižiūnų poligone, savo raportuose kritiškai rašè keli aukšti kariuomenès karininkai, tarp jų ir Šarvuočių rinktinès vadas gen. št. plk. ltn. A. Sidabras. Šiuose dokumentuose pažymima, kad tais metais šaudymo pratimai, skirti tankams „Renault FT 17“, buvo per sunkūs, tad jų sąlygas pajègè ịvykdyti tik labai nedaug šaulių, o tai savo ruožtu neigiamai paveikẻ karių pasiti-

103 Ten pat, 1. 12 . 
kejjimą savo ginklais ir profesionalumu. Tuo pat metu padètis šiuo klausimu tankų „Vickers-Carden Loyd“ pratybose pasirodè esanti visiškai priešinga: jiems skirti šaudymo pratimai buvo ịvertinti kaip per lengvi (juos lengvai atliko beveik visi šauliai), nepasiekiantys mokymo tikslų, priverčiantys švaistyti šaudmenis. Kitais metais kartu su šaudymo pratybų programos pakeitimais siūlyta ịtraukti „prizinius“ šaudymus iš tankų - atitinkami prizai ir apdovanojimai turejo paskatinti šaulius siekti geriausių rezultatų ${ }^{104}$.

Šaudymo pratimams atlikti tankai buvo specialiai ruošiami: dedami $\mathfrak{i}$ juos ginklai ir jų optiniai taikikliai ne iš anksto poligono stovykloje, o tik atvykus ị šaudyklą (nenorèta, kad žygio ị ją metu pastarieji išsiderintų) ${ }^{105}$. 2-osios tankų kuopos „Vickers“ tankų optiniai taikikliai turejjo konstrukcinių ydų, dèl kurių šaudant daromos pataisos neišlikdavo stabilios ir nukentẻdavo šūvių taiklumas. Norint tiksliai pataikyti ị priešo karị vaizduojantị taikinị, šaudant iš $100 \mathrm{~m}$ atstumo, reikejjo taikymosi tašką nustatyti apie 10-30 cm ̣̇ kairę arba dešinę nuo objekto. Šaudant iš $300 \mathrm{~m}$ nuotolio ši pataisa didejo ir taikymosi tašką tekdavo kreipti dar labiau i šoną ten, kur visai nebuvo taikinio. Tankui judant, pataisa nuolat keitèsi, o draudžiant ardyti optinius taikiklius, pašalinti trūkumų vietoje nebuvo galima $^{106}$. Kaip parode šaudymo pratybos, per šiuos optinius taikiklius nebuvo i̇manoma tikrai gerai matyti taikinių, pvz., lietaus lašas, nukritęs ant taikiklio stiklo, galèjo ir visai uždengti šauliui matymo lauką ${ }^{107}$. Be to, optiniai taikikliai važiuojant išsiderindavo - dèl netobulos tvirtinimo konstrukcijos šios taikymo priemonès greitai išklibdavo. I tai buvo atsižvelgta 3-iajai tankų kuopai skirtų kovos mašinų gamybos laikotarpiu, todèl, atlikus nedidelius konstrukcijos pakeitimus, naujesnio modelio

\footnotetext{
104 1938-09-10 Šarvuočių rinktinès vado raportas karo technikos viršininkui, LCVA, f. 828, ap. 1, b. 171, 1. 174-174 a. p.; 1938-09-02 Gaižiūnų poligono II laikotarpio pastabos, LCVA, f. 828, ap. 1, b. 171, 1. 177.

105 1938-11-24 Šarvuočių rinktinès vado raportas karo technikos štabo viršininkui, LCVA, f. 828, ap. 1, b. 171, 1. 179.

106 1938-11-22 Šarvuočių rinktinès 2-osios tankų kuopos vado raportas Technikos skyriaus viršininkui, $L C V A$, f. 828, ap. 1, b. 171, 1. 182; 1938-11-22 Šarvuočių rinktinès technikos dirbtuvių viršininko raportas Technikos skyriaus viršininkui, $L C V A$, f. 828, ap. 1, b. 171, 1. 184; 1938-11-22 Šarvuočių rinktinès mokomojo būrio ltn. Permino raportas būrio vadui, LCVA, f. 828, ap. 1, b. 171, l. 189.

107 1938-11-22 Šarvuočių rinktinès ltn. Meižio raportas Technikos skyriaus viršininkui, LCVA, f. 828, ap. 1, b. 171, 1. 185.
} 
VCL tankų optiniai taikikliai jau neklibejjo. Šarvuočių rinktinėje ardyti ir remontuoti optinius taikiklius buvo draudžiama, o bandymai taisyti ju techninius trūkumus centrinėse artilerijos dirbtuvèse, kurioms ir buvo pavesta ši užduotis, pradèti dar 1935 m., nebuvo sẻkmingi ${ }^{108}$.

Šaudymo pratybas vertinusių karininkų nuomonès dèl eilinių karių šaudymo rezultatų $1938 \mathrm{~m}$. pratybų metu išsiskyrè. Neigiamai vertinusieji jas padarè išvadą, kad kariai per mažai mokomi surasti ir taikytis i taikinị iš stovinčio ir judančio tanko nuolatineje dislokacijos vietoje ${ }^{109}$. Tiesa, tuo metu nuolatineje Šarvuočių rinktinès dislokacijos vietoje Radviliškyje nebuvo tinkamos šaudyklos, kurioje būtų galima mokytis šaudyti iš tankų, nors daliniui vadovavęs gen. št. plk. ltn. A. Sidabras ne kartą i tai atkreipè vadovybès demesị $i^{110}$. Pasak Šarvuočių rinktinès Technikos skyriaus viršininko, mokymo programoje, kiek leidžia galimybès, $\mathfrak{i}$ šaudymo pratybas buvo kreipiamas ypatingas demesys ${ }^{111}$.

O 2-osios tankų kuopos vadas kpt. N. Migevičius buvo patenkintas šaudymo pratybomis, kuriose dalyvavo ir jo vadovaujamo padalinio kariai $^{112}$. Norèdamas tai pailiustruoti, jis pateikè duomenų suvestinę, kurioje buvo pateikti 2-osios tankų kuopos $1938 \mathrm{~m}$. Gaižiūnų poligone surengtų šaudymo pratybų rezultatai ${ }^{113}$. Visi šiame dokumente nurodyti septyni kovinio šaudymo pratimai (vieni, atliekami tankams judant, kiti - stovint), išskyrus vieną tankų būrio pratimą, buvo skirti individualioms

108 1938-11-24 Šarvuočių rinktinès vado raportas Karo technikos štabo viršininkui, LCVA, f. 828, ap. 1, b. 171, 1. 179; 1938-11-25 Šarvuočių rinktinès Technikos skyriaus viršininko raportas rinktinès vadui. LCVA, f. 828, ap. 1, b. 171, 1. 180; 1938-11-22 Šarvuočių rinktinès 2-osios tankų kuopos vado raportas Technikos skyriaus viršininkui. LCVA, f. 828 , ap. 1, b. $171,1.182$.

${ }^{109}$ 1938-11-03 Karo technikos štabo raštas Šarvuočių rinktinès vadui, $L C V A$, f. 828, ap. 1, b. 171, 1. 178; 1938-11-22 Šarvuočių rinktinès ltn. Pustelniko raportas kuopos vadui, LCVA, f. 828, ap. 1, b. 171, 1. 187.

${ }^{110}$ 1938-11-24 Šarvuočių rinktinès vado raportas Karo technikos štabo viršininkui, $L C V A$, f. 828 , ap. 1 , b. $171,1.179$ a. p.

111 1938-11-25 Šarvuočių rinktinès Technikos skyriaus viršininko raportas rinktinès vadui, $L C V A$, f. 828 , ap. 1, b. $171,1.180$.

112 1938-11-22 Šarvuočių rinktinès 2-osios tankų kuopos vado raportas Technikos skyriaus viršininkui, $L C V A$, f. 828 , ap, 1, b. 171, 1. 182 a. p.

113 1938-11-22 2-osios tankų kuopos kautynių šaudymo pratimų 1938 m. sėkmingumo lentelè, $L C V A$, f. 828, ap. 1, b. 171, 1. 183. 
kovos mašinų iguloms ir atliekami tiek karininkų ir puskarininkių, tiek eilinių privalomosios tarnybos karių.

Pirmasis pratimas buvo atliekamas per ribotą laiką šaudant trumpomis serijomis $100 \mathrm{~m}$ atstumu iš stovinčio tanko. Ši užduotis, sprendžiant iš rezultatų, buvo pati lengviausia: ją i̇vykde $100 \%$ karininkų ir puskarininkių ir $95 \%$ eilinių. Antrąj pratimą, nuo pirmojo besiskiriantį tik tuo, kad ji atliekantys kariai turejo mūvèti dujokaukes, ịvykdè $100 \%$ karininkų ir puskarininkių ir $90 \%$ eilinių. Pastebimai sunkesnis pastariesiems buvo trečiasis pratimas, atliekamas šaudant $300-100 \mathrm{~m}$ atstumu iki taikinio iš judančio ir trumpai stabtelejusio tanko. Karininkų ir puskarininkių rezultatai šiuo atveju nesiskyrè nuo ankstesnių (100\% buvo sèkmingi), o eiliniai kariai pasirodè prasčiau - užduotị ịvykdè $66 \%$ iš jų.

Sunkiausias pratimas pasirodè esantis ketvirtasis - šaudymas ị taikinius iš judančio tanko 400-100 m atstumu, kadangi ji sèkmingai pavyko užbaigti $80 \%$ karininkų ir puskarininkių ir tik $38 \%$ eilinių. Penktojo pratimo užduotis buvo, važiuojant ịvairiomis kryptimis $15^{\circ}-25^{\circ} \mathrm{kampu}$ ir trumpai sustojus, šaudyti ị taikinị iš $400-100 \mathrm{~m}$ atstumo. Šis pratimas pasirodè ypač sunkus eiliniams kariams (tik $30 \%$ ji sèkmingai atliko), o karininkai ir puskarininkiai vèl veikè be klaidų ( $100 \%$ ji atliko sèkmingai). Sunkumų kèlè ir šeštasis pratimas, kai reikejo nenurodytu, veikiausiai 400-100 m, atstumu nuo taikinio šaudyti ịvairiomis kryptimis iš $0-90^{\circ}$ kampu judančio tanko, jị valdyti ir stebèti kautynių lauką. Sèkmingai šią užduotį atliko $85 \%$ karininkų ir puskarininkiu ir $46 \%$ eilinių. Galiausiai atliekant paskutinị, septintaji, pratimą, t. y. taikinị atakuojant ir judant visu tankų būriu, sèkmingai pasirode $100 \%$ karininkų ir puskarininkių ir $80 \%$ eilinių ${ }^{114}$.

Kaip matyti, dauguma pratimų buvo atliekami tankams judant, o jų sèkmingo ịvykdymo rezultatai dauguma atvejų (ypač šaudant iš didesnio atstumo) smarkiai skyrèsi nuo pasiektų šaudant iš stacionarios padèties. Taikliai šaudyti iš judančio tanko, kad ir kaip sunku būdavo, buvo labai svarbu pirmiausia dèl tankų ir jų igulų saugumo, kadangi ị važiuojančias kovos mašinas sunkiau pataiko priešo ugnis ${ }^{115}$. Šaudymas iš judančiu tankų nebuvo toks sèkmingas, be minètų taikikliụ trūkumų ir šių pratimų sudètingumo, dar ir dèl kietų tankų pakabų, nes važiuojant nelygia vie-

\footnotetext{
114 Ten pat, 1. 183.

115 Šaudymas iš judančio tanko, Karys, Nr. 33, Kaunas, 1935, p. 764-765.
} 
tove buvo nuolat trūkčiojama ${ }^{116}$. Taikymosi ir šaudymo iš judančių tankų łgūdžiams ugdyti Šarvuočių rinktinès mokomojo būrio patalpose buvo ìrengtas specialus treniruoklis, kurio bokštelyje buvo ịtaisytas kulkosvaidis su optiniu taikikliu ir šviesos koncentratoriumi. Bokštelị du žmonès galèjo judinti ịvairiomis kryptimis, o spaudžiant kulkosvaidžio nuleistuką šviesos koncentratorius lygiagrečiai su ginklo vamzdžiu nukreipdavo spindulį, imituojantị šūvio liniją ir, derinant jị su optinio taikiklio ašimi, leidžiantị mokytis greitai ir tiksliai nusitaikyti ${ }^{117}$.

3-iosios tankų kuopos, kurios VCL tankų optiniai taikikliai, kaip minèta, turèjo mažiau trūkumų nei 2-osios kuopos taikymosi priemonès, 1938 m. Gaižiūnų poligone atliktų šaudymo pratimų rezultatų suvestinèje nurodytas didesnis sèkmingai užduotis atlikusių karių skaičius ${ }^{118}$. Anksčiau aptartus septynis šaudymo pratimus 3-iojoje tankų kuopoje atliko 3 karininkai, 8 puskarininkiai ir 17-24 eiliniai. Kuopos karininkai ir puskarininkiai šiose pratybose pasirodè labai gerai, kadangi net penkis iš šešių individualių tankų iguloms skirtų pratimų visi atliko be klaidų (100\% sèkmingai). O privertè suklysti ketvirtasis pratimas, kèlęs daugiausia sunkumų ir 2-osios kuopos šauliams: jo sąlygas sèkmingai ịvykdè 33 \% (t. y. vienas iš trijų) karininkų ir 50 \% (keturi iš aštuonių) puskarininkių. Pratimus sèkmingai atlikusių eilinių 3-iosios kuopos karių skaičius svyravo labiau, tačiau apskritai tokių buvo daugiau nei jų kolegų iš 2-osios tankų kuopos. Pirmąji šaudymo pratimą sẻkmingai atliko $80 \%$, antrąji - $100 \%$, trečiajj - $90 \%$, ketvirtajji - $50 \%$, penktąji - $95 \%$, šeštąji tik $25 \%$ kuopos eilinių karių. Septintąj šaudymo pratimą, skirtą visam tankų būriui, sèkmingai atliko du iš trijų (75\%) dalyvavusių būrių ${ }^{119}$.

Tankų iguloms ir padaliniams Lietuvos kariuomenès keliamus šaudymo igūdžių ir taktikos reikalavimus gerai iliustruoja $1940 \mathrm{~m}$. balandžio mèn. tuomečio kariuomenès vado div. gen. V. Vitkausko patvirtinta šaudymo pratimų tankams programa ${ }^{120}$. Joje buvo numatyta dešimt moko-

\footnotetext{
116 1938-11-22 Šarvuočių rinktinès 2-osios tankų kuopos vado raportas Technikos skyriaus viršininkui, $L C V A$, f. 828 , ap. 1, b. 171, 1. 182 a. p.

${ }^{117}$ Karo technikos dalių dvidešimtmetis 1919-1939, p. 206.

118 1938-11-22 Šarvuočių rinktinès 3-ios tankų kuopos atliktų Gaižiūnų poligone šaudymo pratimų žinios, LCVA, f. 828, ap. 1, b. 171, 1. 186.

119 Ten pat, 1. 183.

120 1940-04-27 Šarvuočių rinktinės iš „Vickers“ ir „Renault“ tankų kulkosvaidžių šaudy-
} 
mojo šaudymo pratimų, atliekamų pirmaisiais mokymo metais, ir tiek pat kovinio šaudymo pratimų, skirtų antriesiems mokymo metams. Šaudoma turejo būti tiek iš „Renault FT 17“, tiek iš „Vickers-Carden Loyd“ modelių tankų. Visi pratimai turèjo savo temas, tikslus, kurių reikèjo siekti mokant kovos mašinų igulas.

Mokomojo šaudymo programos tikslas buvo išmokyti: 1) taikliai taikytis, 2) šaudyti sutelktąja ugnimi, 3) pereiti iš sutelktosios i išplèstąją ugni, 4) šaudyti trumpomis serijomis keičiant taikinius, 5) šaudyti mūvint dujokaukes, 6) šaudyti trumposiomis serijomis per ribotą laiką, 7) šaudyti ị judančius taikinius ${ }^{121}$. Visi dešimt mokomųjų pratimų turèjo būti atliekami iš vietoje stovinčių tankų. Tiesa, dauguma kitų pratimų reikalavimų buvo padalyti į skirtus „Vickers“ ir „Renault“ tankams. Priklausomai nuo konkretaus pratimo, šie reikalavimai arba sutapdavo, arba buvo skirtingi. Dauguma mokomojo šaudymo pratimų buvo numatyta atlikti iš $25 \mathrm{~m}$ atstumo, tačiau, šaudant trumposiomis serijomis per ribotą laiką ir atliekant pratimą mūvint dujokaukes, šis nuotolis išaugo iki 100 m „Vickers“ ir 75 m „Renault“ kovos mašinoms. Kiekvienai užduočiai, atliekamai arba pavieniais šūviais, arba trumposiomis šūvių serijomis, buvo skirta nuo 3 iki 20 šovinių. Dalies užduočių šaudymo laikas taip pat buvo ribotas. Daugiausia jo buvo skirta šaudymui $\mathfrak{i}$ judančius taikinius: iš „Vickers“ tankų - 90 s, iš „Renault" - 135 s. Atliekant kitus riboto laiko pratimus pastarosios kovos mašinos taip pat turejjo $15 \mathrm{~s}$ daugiau laiko („Vickers“ buvo skirta 30-45 s, „Renault“ - 45-60 s). Užduočių taikiniai, ịskaitant ir judančius, daugiausia vaizdavo lengvojo kulkosvaidžio poziciją. Atliekant pratimus su judančiais taikiniais, pastarieji per numatytą laiką (priklausomai nuo tanko modelio - 90 arba 135 s) judèdavo $10 \mathrm{~m}$ tik horizontalia arba horizontalia ir vertikalia kryptimis. Trims iš didesnio nuotolio (100 ir $75 \mathrm{~m}$ ) atliekamiems pratimams buvo skirti penki žmogaus krūtinès arba juosmens taikiniai, išskleisti ị liniją $5 \mathrm{~m}$ atstumu vienas nuo kito. Mokomųjų šaudymo užduočių îvykdymo sąlygos, priklausomai nuo pratimo, nebuvo visiškai vienodos, tačiau visada palankesnès „Renault FT 17“ tankams. Šių kovos mašinų šauliams atliekant visus pratimus leista kliudyti vienu taikiniu mažiau nei jų kolegoms VCL tankuose, taip pat, vykdant kelias užduotis, pataikyti dviem

mo programa, $L C V A$, f. 828 , ap. 1, b. 247, 1. 1-2.

121 Ten pat, 1.1. 
šūviais mažiau arba pasiekti didesnę pataikytų šūvių sklaidą ị aukštị ir plotị (atitinkamai 32 ir $16 \mathrm{~cm}$, o ne 24 ir $8 \mathrm{~cm}$ šaudant iš VCL) ${ }^{122}$.

Kovinio šaudymo programa, kurią sudare dešimt pratimų, buvo gerokai sudètingesnè ir turejo, sprendžiant iš keliamų tikslų, parengti tankų igulas individualiai ir būrio sudètyje atlikti užduotis panašiomis ị tikrą kovą aplinkybėmis. Kovinio šaudymo pratimų tikslai buvo išmokyti: 1) sekti taikinius tankui važiuojant ir greitai šaudyti jam sustojus, 2) šaudyti ị judančius taikinius, 3) šaudyti mūvint dujokaukę, 4) sekti taikinị važiuojant vingiais ir greitai šaudyti tankui sustojus, 5) taikyti ir šaudyti judant, 6) tanko vadą vadovauti taikantis ir šaudant judant, 7) stebèti kautynių lauką, 8) tankų būrị šaudyti, vienam skyriui puolant iš priekio, kitam - iš sparno, $45^{\circ} \mathrm{kampu}^{123}$. Skirtingai nuo mokomųų šaudymo pratimų, šie pratimai turèjo būti atliekami nebe stovint vietoje, o važiuojant ir dauguma atvejų trumpai stabtelint iššauti arba tik sumažinant greiti iki $6 \mathrm{~km} / \mathrm{val}$. (VCL) ar 3-4 km/val. („Renault“). Buvo du pratimai, kai reikejo, puolant taikini, važiuoti pagrindine kryptimi vingiuojant $20^{\circ}-30^{\circ} \mathrm{kampu}$. Tankams „Vickers“, atsižvelgiant ił užduotị, buvo nustatytas 10-15 km/val., o „Renault“ - 4-6 km/val. greitis. Skyrèsi ir maksimalus užduoties atlikimo nuotolis: „Vickers“ jis siekè 300 arba 400 m, „Renault" - 250 arba 300 m, o minimalus visais atvejais - $100 \mathrm{~m}$. Pratimui atlikti skirtų šovinių skaičius buvo vienodas abiejų tipų tankams ir svyravo nuo 15 iki 60, o šaudymo laikas skirtingiems pratimams atlikti turëjo siekti 8-15 s (VCL) arba 10-20 s („Renault“). Taikiniai visiems tankams buvo vienodi. Septyniuose iš dešimties pratimų buvo naudojami penki krūtinès arba juosmens išskleisti ị liniją, o dviejuose $-5 \mathrm{~km} / \mathrm{val}$. greičiu statmenai šaudymo krypčiai judantys taikiniai. Pagal šių pratimų atlikimo sąlygas, „Vickers“ tankai turèjo trimis šūviais kliudyti bent 2 iš 5 minètų taikinių, o tankai „Renault“ - dviem šūviais kliudyti bent 1 iš 5 . Tik viename, septintajame, kovinio šaudymo pratime, kurị atliekant penki krūtinès taikiniai turèjo būti apšaudomi iš judančio tanko, „Vickers“ iguloms keliami reikalavimai sumažèjo - jie dviem šūviais turejjo kliudyti tik vieną taikini, o „Renault“ kovos mašinomis šio pratimo visai nereikejjo atlikti. Atliekančios aštuntajji kovinio šaudymo pratimą visų tankų igulos turejo, atitinkamai sumažinusios greiti, atakuoti $200 \mathrm{~m}$ skersmens plote išdèsty-

\footnotetext{
122 Ten pat, 1. 1.

123 Ten pat, 1. 2.
} 
tas tris taikinių grupes po 4-5 juosmens taikinius, kurių viena išdèstyta $100 \mathrm{~m}$ ị gilumą. Tokiu būdu, ko gero, siekta pavaizduoti priešo pėstininkų skyrių, sudarytą iš trijų grandžių. Tankai „Vickers“ kiekvienoje iš šių taikinių grupių turejo 5 tiksliais šūviais kliudyti po vieną taikinị, o tankai „Renault“ -3 šūviais po vieną taikinį dviejose grupèse. Devintojo pratimo tankų taikiniai vaizdavo didžiausią grèsmę jiems mūšio lauke keliančius priešiškų pajègų kovos vienetus - vieną prieštankinio pabūklo poziciją ir $100 \mathrm{~m}$ atstumu už jos kas minutę pasirodantị judantị tanką. Šios užduoties tikslas buvo ịpratinti šauli sekti kovos lauką, ją atliekant reikejo, kad ir „Vickers“, ir „Renault" tankai, šūviams atlikti sumažinę greitị arba trumpai sustoję, kliudytų abu taikinius. Paskutinis, dešimtasis, kovinio šaudymo pratimas buvo skirtas visam tankų būriui. Šị kartą $300 \mathrm{~m}$ plote išdèstyti krūtinès taikiniai vaizdavo visos sudèties priešo pėstininkų būrị, sudarytą iš kelių skyrių ir remiamą iš dviejų sunkiųjų kulkosvaidžių pozicijų. Atlikdamas užduotị, tankų būrys turèjo pasidalyti ị du skyrius ir, sumažinęs greitị arba trumpai stabtelèjęs, paleisti ugnị, atakuoti taikinị iš priešakio ir sparno ir kliudyti kiekvieną kulkosvaidžio lizdą ir pėstininkų skyrių ${ }^{124}$.

Pažymėtina, kad visų kovinio šaudymo pratimų atlikimo sąlygos, taip pat kaip ir mokomojo šaudymo metu, naudojant „Renault FT 17“ tankus, buvo ne tokios griežtos, kaip nustatytos „Vickers-Carden Loyd“ iguloms. Mažesnis reikalaujamų kliudyti taikinių ar pataikymų i juos skaičius liudija ir prastesni, palyginti su gerokai naujesniais „Vickers“ tankais, prancūziškųjų tankų taiklumą, ko gero, nulemtą pirmiausia kovos mašinų, jų ginkluotès amžiaus ir techninio susidèvejimo. Nepaisant to, abiejų tipų tankai veikè, kaip parodè minèti šaudymo pratimai, labai panašiai. Jų iguloms buvo vienodai svarbu atidžiai sekti kovos lauką, sunkiaisiais kulkosvaidžiais apšaudyti aptiktus taikinius, tankams toliau judant i prieki arba tik trumpai stabtelèjus paleisti ugnị iš stabilesnès pozicijos ir nuslopinti arba išvesti juos iš rikiuotès nepriartèjus arčiau kaip $100 \mathrm{~m}$ atstumu. Be to, buvo būtina atakos metu pavieniams tankams ar visam jų junginiui manevruoti, o ne judèti tiesia linija, kad priešui bùtų sunkiau pataikyti i juos, arba, išstačius šarvą, atsižvelgiant ị grèsmę, atitinkamu kampu, padidinti jų atsparumą ir sutelkti ugnị i pavojingiausius taikinius ${ }^{125}$. Tankų

\footnotetext{
124 Ten pat, 1. 2.

${ }^{125}$ Pečiūra, Kaip tankų būrys puola ịvairius taikinius, Karys, Nr. 28, Kaunas, 1936, p. 684-686.
} 
pagrindiniai taikiniai, kaip ir anksčiau, liko pėstieji priešo kariai, ypač juos remiantys sunkieji ginklai.

\subsection{Tankų judèjimas kovos lauke}

Kaip matyti iš pateiktų kovinio šaudymo pratimų duomenų, buvo labai svarbu, kad tankai judètų mūšio lauke. Greitis ir manevringumas turejjo padèti jiems išvengti priešo ugnies ar bent sumažinti jos naikinamąji poveikį, be to, leisti nuosekliai plètoti priešo pozicijų puolimą. Kaip ir kitų manevrinių sausumos pajėgų vienetų, šarvuotųjų dalinių judejjimas žygio ar kautynių metu turẻjo vykti ne gaivališkai, o remiantis tam tikromis kovos vienetų, padalinių rikiuotemis, patvirtintomis kariuomenès vadovybės. Šios rikiuotès turèjo padèti išlaikyti tankų veiksmų darną, tvarką ir veiksmingumą.

Lietuvos kariuomeneje tankų būrys, sudarytas iš dviejų skyrių po dvi kovos mašinas kiekviename iš jų ir būrio vado tanko, galintis veikti tiek kuopos sudètyje, tiek savarankiškai, naudojo keturių tipų reglamentuotas rikiuotes: „tankinę“ (t. y. tankiąją), žygio, manevrinę artèjimo ir manevrinę kautynių ${ }^{126}$. „Tankine““ rikiuotė buvo naudojama tik mokantis arba per paradus ir jungè tris rikiuotes: 1) būrys voroje, 2) būrys linijoje, 3) būrys skyrių voroje. Šiomis rikiuotemis tankai važiuodavo gerokai arčiau vienas kito (3-5 m atstumu). Vienintelè žygio rikiuotẻ buvo žygio vora, kurios priešakyje turèjo važiuoti pats būrio vadas. $1935 \mathrm{~m}$. atstumas tarp „Renault" tankų turèjo siekti $10 \mathrm{~m}$, o tarp „Vickers“ - 10-20 m²7. O $1938 \mathrm{~m}$. schemose matome, kad atstumas tarp tankų žygio voroje išaugo iki $25 \mathrm{~m}^{128}$. Daugiausia buvo manevrinès artëjimo rikiuotès, naudojamos artėjant prie priešo ir tikintis sąlyčio su juo, variantų: 1) būrys skyrių voroje (apverstos „U“ formos rikiuotè, skirta judèti per tam tikras kliūtis, raižyta vietove), 2) būrys trikampèj rikiuotėj kampu pirmyn (pleišto rikiuoté, leidusi abiem tankų skyriams lengvai išvystyti puolimą i priešo sparnus), 3) būrys tri-

\footnotetext{
${ }^{126}$ 1935-04-06 Pagrindinès tankų-tankečių būrio rikiuotès, LCVA, f. 828, ap. 1, b. 102, 1. 34-36 a. p.; 1938-02-17 Tankų komandos ir rikiuočių formos, $L C V A$, f. 828, ap. 1, b. 170, 1. 5-6 a. p.

127 1935-04-06 Pagrindinès tankų-tankečių būrio rikiuotès, $L C V A$, f. 828, ap. 1, b. 102, 1. 34-35.
}

128 1938-02-17 Tankų komandos ir rikiuočių formos, LCVA, f. 828, ap. 1, b. 170, 1. 5. 
kampejj rikiuotej kampu atgal (V formos rikiuotè, leidusi lengvai manevruoti tankų skyriais, šaudyti ịstrižąja ugnimi), 4) būrys nuožulniai kairèn (rikiuote, skirta kairiajam būrio sparnui apsaugoti), 5) būrys nuožulniai dešinèn (skirta dešiniajam būrio sparnui apsaugoti), 6) būrys voroje.

1935-1936 m. nurodoma, kad visais šiais atvejais atstumai tarp tankų turèjo siekti 30-50 m, o būrio vadas - užimti priešakinę poziciją (išskyrus „V“ rikiuotę, kurioje jo vieta buvo apatiniame kampe) ${ }^{129} .1938 \mathrm{~m}$. schemose matyti, kad bent pleišto ir nuožulniųjų formų rikiuotėse nuotolis tarp būrio kovos mašinų padidèjo iki $50-100$ m, o būrio vado vieta nuožulniosiose rikiuotėse buvo perkelta iš priešakinès ị vidurinę poziciją $a^{130}$. Rikiuotès pasirinkimas turëjo priklausyti nuo konkrečiu aplinkybiu - vietovès sąlygų ar taktinès padèties. Vienintelè manevrinè kovos rikiuotè numatė būrio išsiskleidimą ị liniją, geriausiai leidusią sutelkti tiesioginę ugnị, padalinio vadui užèmus vietą centre ir tankams, pagal 1935-1936 m. schemas, esant 30-50 m arba, pagal $1938 \mathrm{~m}$. schemas, $50-100 \mathrm{~m}$ atstumu vienas nuo kito ${ }^{131}$.

Tankų kuopos - didžiausi tankų junginiai Lietuvos kariuomeneje turéjo vadovautis joms nustatytomis rikiuotemis, suskirstytomis $\mathfrak{i}$ jau minètus keturis tipus ${ }^{132}$. Mokymams ir paradams skirtomis "tankinèmis“ rikiuotemis kuopa judejjo išlaikydama mažesnius nei kitais atvejais atstumus tarp savo padalinių (būrius turèjo skirti $10 \mathrm{~m}$ ) ir formuodama vieną iš trijų rikiuočių: voros, linijos arba būrių voros. Žygiui besirengianti tankų kuopa, kaip ir tankų būrys, turëjo rikiuotis žygio vora, kad tarp būriu ir priešakyje važiuojančios kuopos vado mašinos liktų 30-50 m atstumas ${ }^{133}$. Manevrinès artëjimo rikiuotès, naudojamos kuopai artejjant

\footnotetext{
129 1935-04-06 Pagrindinès tankų-tankečių būrio rikiuotès, $L C V A$, f. 828, ap. 1, b. 102, 1. 35-35 a. p.; J. ltn. Pečiūra, Tankų būrys ir jo rikiuotès, Karys, Nr. 27, Kaunas, 1936, p. $658-660$.

${ }^{130}$ 1938-02-17 Tankų komandos ir rikiuočių formos, $L C V A$, f. 828, ap. 1, b. 170, 1. 6.

131 1935-04-06 Pagrindinès tankų-tankečių būrio rikiuotès, LCVA, f. 828, ap. 1, b. 102, 1. 35 a. p.; 1938-02-17 Tankų komandos ir rikiuočių formos, $L C V A$, f. 828, ap. 1, b. 170, 1. 6; J. ltn. Pečiūra, Tankų būrys..., p. 659.

132 1936-03-18 Pagrindinès tankų-tankečių kuopos rikiuotès, $L C V A$, f. 828, ap.1, b. 122, 1. 19, 22-22 a. p., 35-35 a. p.; 1938-02-17 Tankų komandos ir rikiuočių formos, LCVA, f. 828 , ap. 1, b. $170,1.5$ a. p., 6 a. p.

133 1936-03-18 Pagrindinès tankų-tankečių kuopos rikiuotès, $L C V A$, f. 828, ap.1, b. 122, 1. 19,35 .
} 
prie priešo, rengiantis sąlyčiui su juo, buvo trejopos: 1) trikampe rikiuotè kampu pirmyn, 2) trikampé rikiuotè kampu atgal, 3) kuopos būriai linijoje. Pirmuoju atveju vienas iš būrių stodavo i̇ priešakinę poziciją, o likę du - jo užnugaryje, nuožulniai ị kairę ir dešinę. Antroji trikampès rikiuotès forma buvo pagrịsta atvirkštine tvarka - du būriai juda pirmojo priekyje, nuožulniai ị dešinę ir kairę puses. Naudojantys trečiąją artėjimo rikiuotę visi trys kuopos būriai turejjo išsirikiuoti į vieną liniją. Visais trimis minètais atvejais nustatytieji atstumai tarp tankų būrių turejjo siekti 200-300 m. Kuopos vadas šiose rikiuotèse važiuodavo 30-50 m priešais vidurinę poziciją užimantị būrị. Tiesa, nuotoliai, atskirų tankų būrių rikiuotès ir vieta bendroje kuopos rikiuoteje, priklausomai nuo taktiniu aplinkybių ir vietovès sąlygų, galejjo būti keičiami ${ }^{134}$.

Tankų kuopai buvo numatytos net septynios manevrinès kovos rikiuotès, kuriomis išsidėstęs šis padalinys turèjo stoti ị kovą su priešo pajègomis. Pirmosios dvi kovos rikiuotès savo būrių išsidèstymo forma priminè statųjt trikampį: pirmasis ir antrasis būriai turèjo išsirikiuoti vienoje tiesejje 50-100 m atstumu vienas nuo kito, o trečiasis būrys - 200-300 m už vieno iš jų, važiuojančio kairiajame arba dešiniajame sparne. Giliojoje rikiuotèje kuopos būriai turèjo išsirikiuoti kolona, 200-300 m atstumu vienas už kito. Minètų kovos trikampio ir giliosios rikiuočių priešakyje esantys būriai judejjo ị priekị išsiskleidę i liniją, o kiti būriai, formuojantys antrąji ar trečiąji kuopos ešelonus, galejo išsirikiuoti ir kitaip, priklausomai nuo vietovès ir taktinių aplinkybių ${ }^{135}$. Formuojant plačiąją rikiuotę, pagal 1936 m. nuostatus, buvo numatytas kuopos būrių išsiskleidimas i vieną liniją 50-100 m atstumu vienas nuo kito, o pagal $1938 \mathrm{~m}$. schemas, šis nuotolis jau buvo didesnis - iki $200-300 \mathrm{~m}^{136}$. Giliojoje ir plačiojoje rikiuotèse kuopos vado pozicija buvo $50-100 \mathrm{~m}$ prieš jo vedamus būrius $^{137}$. Buvo numatytos dar trys manevrinès tankų kuopos kovos rikiuotès: „replès“, „frontas-dešinysis sparnas“ ir „frontas-kairysis sparnas“. Išsidèsčiusi „replių“ rikiuote tankų kuopa turejo įveikti priešo poziciją,

\footnotetext{
134 Ten pat, 1. 19, 35 a. p.

135 Ten pat, 1. 19, 22, 35 a. p.

${ }^{136}$ Ten pat, 1. 19; 1938-02-17 Tankų komandos ir rikiuočių formos, LCVA, f. 828, ap. 1, b. $170,1.6$ a.p.

137 1936-03-18 Pagrindinès tankų-tankečių kuopos rikiuotès, LCVA, f. 828, ap.1, b. 122, 1. 22.
} 
rikiuotès viduryje esančiam būriui su kuopos vadu atakuojant ir sukaustant priešą frontaliai, o likusiems dviem būriams išsiveržiant ị priekị, taikantis apsupti priešą ir kartu smogti ị abu jo sparnus. Išsidèsčiusi rikiuote „frontas-sparnas“ kuopa siekè pagrindinėmis savo pajègomis pulti vieną iš priešo sparnų. Tai turèjo būti atliekama vienam iš būrių puolant ir sukaustant priešą frontaliai, o kitiems dviem būriams, išsidėsčiusiems ị kairę arba dešinę nuo pirmojo, kreipiant savo puolimo kryptị i kairijj arba dešinijji priešo sparną ir jị apglèbiant. Atstumas tarp atakuojančių būrių, išsidèsčiusių tiek „replių“, tiek „frontas-sparnas“ rikiuote, priklausè nuo vietovès sąlygų ${ }^{138}$. Kaip matyti, galima pastebėti tendenciją tankų rikiuotèse plèsti atstumus tarp būrio ar kuopos kovos mašinų. Deja, bet nepavyko rasti dokumentų, pagrindžiančių tokius pokyčius. Galima tik daryti prielaidą, kad plečiant atstumus tarp tankų siekta padaryti jų junginius mažiau pažeidžiamus, labiau apsaugotus nuo priešo ugnies.

Kad tankų junginių veiksmai kovos lauke būtų darnūs, būtinai reikejjo palaikyti glaudžius ryšius tarp padalinių vadų ir likusių tankų. Padalinių, kurie turèjo VCL tankų, kuopos ir būrių vadų kovos mašinose buvo sumontuotos radijo stotys, sudarytos iš siųstuvo su mikrofonu ir imtuvo su ausinemis. Šiomis radijo stotimis ryšys tarp judančių tankų galëjo būti palaikomas 4-6 km, stovint vietoje $-8-12 \mathrm{~km}$ atstumu ${ }^{139}$. O Lietuvos kariuomenès „Renault FT $17^{\text {“ }}$ radijo įrangos neturèjo ${ }^{140}$. Be radijo ryšio priemonių, pagrindine komandų perdavimo ir padalinio valdymo priemonè tankų kuopų ar būrių vadams buvo skirtingų spalvų vèliavèlès. Iš 1935-1936 m. dokumentų matome, kad tankų būrių ir kuopų rikiuotès turejjo atitinkamus sutartinius ženklus, išreiškiamus viena tam tikros spalvos vèliavèle arba dviem skirtingų spalvų vèliavèlèmis ${ }^{141} .1938 \mathrm{~m}$. tankų rikiuočių ir atskirų komandų sutartinius ženklus apibūdinančiame dokumente pagrindinis akcentas yra ne vèliavèlių spalva, o jas naudojant rodomi tam tikri ženklai rankomis. Kiekviena žygio ir manevrinè rikiuotè turejjo ją atitinkantị, rankomis viena arba dviem vèliavèlèmis rodomą

\footnotetext{
138 Ten pat, 1. 19, 22-22 a. p.

${ }^{139}$ A. Pociūnas, A. Stoliarovas, min. veik., p. 20.

${ }^{140}$ V. Grigoraitis, Lietuvos kariuomenès technika 1918-1940 m., p. 104.

${ }^{141}$ 1935-04-06 Tankų būrių sutartiniai ženklai, $L C V A$, f. 828, ap. 1, b. 102, 1. 34; 1936 m.

Tankų-tankečių kuopos sutartiniai ženklai, LCVA, f. 828, ap. 1, b. 122, 1. 25.
} 
signalą ${ }^{142}$. Visi būrio tankai turèjo dvi vèliavèles - pagrindinę ir pagalbinę. Būrio vado pagrindinès vèliavèlès spalva skyrèsi nuo kitų tankų vadụ naudojamų analogiškų vèliavèlių spalvų, o pagalbinès viso padalinio vèliavèlès buvo vienos spalvos. İsakymų perdavimo procedūra šiomis ryšio priemonėmis atrodè gana komplikuota. Pirmiausia būrio vadas turèjo iškelti vèliavèlę ir ja duoti savo padaliniui ženklą „Dèmesio“. Tik po to, kai ši ženklą pakartodavo skyrių vadai, jis galejjo rankų judesiais ir vèliavèlėmis duoti norimą ịsakymą dèl atitinkamos rikiuotès. Šis signalas turejjo būti kartojamas tol, kol ji pakartos skyrių ir galiausiai eilinių kovos mašinų vadai ${ }^{143}$. Tankų kuopos rikiavimui ir valdymui skirti sutartiniai ženklai buvo tokie pat kaip ir tankų būriams. Kuopos vado perduodamus ìsakymus turejjo perimti tik būrių vadai, kurie, kuopai persirikiuojant, savarankiškai surikiuodavo savo vadovaujamus junginius, atsižvelgdami ¿̇ vietovę ir taktines aplinkybes. Taip pat kaip ir tankų būryje, kuopos vadas pirmiausia turèjo, iškeldamas vèliavèlę, duoti ženklą „Dėmesio“, kurị pakartodavo būrių ir kitų tankų vadai. Tuomet kuopos vadas galèjo duoti norimą rikiuotę reiškiantị ženklą, kurio būrių vadams jau nebereikejjo kartoti, o tik vesti savo padalinius atitinkama tvarka ${ }^{144}$.

\subsection{Tankų padalinių bendradarbiavimas su pèstininkais}

Lietuvos kariuomenès negausūs ir techniškai ribotų kovinių galimybių šarvuotieji padaliniai nebuvo pajègūs suvaidinti nors kiek svaresnio savarankiško vaidmens šalies ginkluotoje gynyboje. Tačiau, nepaisant to, jie turejjo aiškiai nustatytą vietą galimo ginkluoto konflikto atveju. Pagrindinė jų užduotis buvo paremti ir sustiprinti kitas pajejgas. Visų pirma ši parama turejjo būti skirta Lietuvos kariuomenès péstininkų ir kavalerijos daliniams. Pèstija, gausiausia kariuomenès ginklų rūšis ir jos pajègumo pagrindas, buvo bene svarbiausia šio kovinio bendradarbiavimo su tankų padaliniais partnerè.

Pèstininkų ir tankų padalinių bendradarbiavimo kovos lauke principai ir būdai nurodyti Pèstininkų statuto antrojoje, kautynèms skirtoje, dalyje. Ši pėstininkų mokymo priemonè kartu yra ir bene svarbiausias

142 1938-02-17 Tankų komandos ir rikiuočių formos, LCVA, f. 828, ap. 1, b. 170, 1. $3-4$ a. p.

${ }^{143}$ Ten pat, $1.3-3$ a. p.

144 Ten pat, 1. 4 a. p. 
žinių apie Lietuvos kariuomenès šarvuotųjų pajègų, pirmiausia tankų, veiksmų mūšyje teorinius pagrindus šaltinis. Šiam darbui aktualiausias 1939 m. išleistas Pèstininkų statutas ${ }^{145}$.

Pėstininkų ir tankų padalinių kovinio bendradarbiavimo pagrindinị principą puikiai iliustruoja Pėstininkų statute pabrèžiamas teiginys, kad šarvuotosios kovos mašinos yra tik pagalbinè pèstininkų kovos priemonè, nes jie turi gebèti atlikti savo kovines užduotis ir be šios pagalbos, jei šarvuočiai ar tankai išeitų iš rikiuotès ar per toli atsiliktų ${ }^{146}$. Tankų priskyrimas pèstininkų daliniui dažniausiai suvokiamas kaip trumpalaikis reiškinys, skirtas padèti pastarajam atlikti konkrečias kovines užduotis.

Toks priskyrimas iš esmès nekeitè pėstininkų veikimo kovos lauke būdų, tačiau turejo ịtakos užduoties vykdymo parengiamiesiems ir planavimo darbams. Pėstininkai taip pat buvo ịpareigoti saugoti tankus. Tuo pat metu tankų pagrindinè užduotis, kaip minèta, buvo padèti pėstininkams nugalèti priešą, kulkosvaidžių ugnimi naikinant jo gyvąją jègą arba savo svoriu - sunkiąją ginkluotę, pralaužiant gynybines užtvaras (pvz., spygliuotos vielos kliūtis). Šiuo atveju itin svarbų vaidmenị vaidino tankų sunkiųjų kulkosvaidžių veiksmingos ugnies nuotolis: naikinamosios ugnies ił gerai matomus taikinius - iki $400 \mathrm{~m}$ (iš tokio nuotolio buvo šaudoma ir atliekant šaudymo pratimus), slopinamosios ugnies - iki 600-700 m ${ }^{147}$. Akcentuota, jog būtina siekti, kad tankai kautynių lauke pasirodytų priešui netikètai, pvz., palyginti triukšmingomis ir gerai matomomis kovos mašinomis prie kovos lauko priartèti pasinaudojus nakties ar rūko priedanga ${ }^{148}$.

Vis delto svarbiausia, vykdant bendras kovines užduotis, - glaudus ir gerai suplanuotas pèstininkų ir tankų padalinių bendradarbiavimas: abiejų rūšių pajègų vadai turèjo iš anksto suderinti visas kautynių plano smulkmenas, o péstininkai - nedelsdami pasinaudoti jų naudai veikiančių tankų pasiektais rezultatais, juos remti ugnimi ir, jei prireiktų, fizinèmis jègomis ir nereikalauti, kad šarvuotieji padaliniai vieni visiškai nuslopintų priešo pasipriešinimą. Pėstininkų daliniams priskirti tankai būdavo įtraukiami ì jų struktūrą, o jų vadai tapdavo pavaldūs dalinių vadams. Orientuojantis ị péstininkų galimybes numatytos kovinès už-

\footnotetext{
${ }^{145}$ Péstininku statutas P-51, II dalis. Kautynès. 2 laida, p. 202-216.

146 Ten pat, p. 202.

147 Ten pat, p. 202-206.

148 Ten pat, p. 206.
} 
duoties pobūdis, vietovès sąlygos ir priešo pozicijos turèjo lemti konkretų paramai numatomų skirti tankų skaičių, nors pagrindiniu koviniu jų vienetu buvo laikomas tankų būrys. Taip pat numatyta, kad dažniausia užduotims vykdyti vienam péstininkų batalionui bus priskirtas vienas tankų būrys, o susidūrus su stipresniu priešu, jei įmanoma - viena tankų kuopa. Tankų kuopos vado užduotis - likti prie pèstininkų dalinio vado, kuriam priskirtas jo vadovaujamas padalinys, ir būti jo patareju kovos mašinų panaudojimo klausimu, kartu palaikyti ryši su tankų būriais, rūpintis tiekimu ir ịvairiais techniniais klausimais ${ }^{149}$.

Tankų panaudojimo taktika gerai ịsitvirtinusio priešo puolime turèjo būti kruopščiai suplanuota ir parengta vadovaujantis nustatyta tvar$\mathrm{ka}^{150}$. Visų pirma, rengiantis puolimui, jie turèjo būti išsidèstę maždaug už kelių kilometrų nuo išeities pozicijos, t. y. puolimo pradžios ribos. Iš šios vietos tankų junginio vadas, remdamasis pėstininkų dalinio vado sumanymu, turejo vykti išeities pozicijos žvalgyti. Šiuo atveju jo pagrindinè užduotis buvo rasti geriausius kelius, kuriais tankai galètų pasiekti puolimo pradžios ribą, kruopščiai ir atidžiai išžvalgyti tiek ją, tiek priešo poziciją. Remiantis šios žvalgybos metu surinktomis žiniomis, pėstininkų vadui turèjo būti pateiktas siūlymas dèl geriausio įmanomo esamomis aplinkybėmis tankų panaudojimo būsimajame puolime varianto. Puolimui vadovaujančio pėstininkų dalinio vadas savo ruožtu, išklausęs siūlymus, turèjo priimti sprendimą ir duoti įsakymą, kuriame būtų nurodyta: 1) kuriems vienetams tankai yra priskiriami; 2) išeities (puolimo pradžios) riba ir šios pozicijos užėmimo laikas; 3 ) puolimo pradžia ir jo tvarka; 4) eiliniai ir galutinis puolimo tikslai; 5) numatoma parama tankams ugnimi; 6) susitelkimo vieta, pasiekus galutinị tikslą; 7) sutartiniai ženklai ryšiui tarp pėstininkų ir tankų palaikyti ${ }^{151}$.

Tiesa, kaip parodè pratybos poligonuose, praktiškai toli gražu ne visada pavykdavo laikytis šių procedūrų. Pavyzdžiui, aptardamas 1936 m. kariuomenès manevrus, Šarvuočių rinktinès vadas padare išvadą, kad tankų būrių vadams įsakymai dažniausiai duodami skubotai ir yra neaiškūs. Be to, jie verčiami pernelyg rizikuoti ir vykti ị kautynes prieš tai neišžvalgius vietovès, nežinant, kur tiksliai yra priešas, iš anksto nespejjus supažindin-

149 Ten pat, p. 206-207.

150 Ten pat, p. 208-210.

151 Ten pat, p. 208-210. 
ti tankų igulų su esamomis aplinkybėmis ${ }^{152}$. Panašias išvadas matome ir karo technikos viršininko pastabose dèl šarvuotųjų padalinių veikimo tų pačių metų mokymų Gaižiūnų poligone metu ${ }^{153}$. Visų pirma pastebèta, kad péstininkų dalinių vadai prastai susipažinę su techninėmis ir taktinėmis tankų panaudojimo sąlygomis, todèl kartais duoda ịsakymus, kurių tankų ekipažai paprasčiausiai negali įvykdyti. Be to, pėstininkų vadai, duodami issakymus tankų padaliniams, nesuteikia jiems pakankamai laiko pasiruošti užduočiai vykdyti, t. y. žvalgybai atlikti, ryšiui su pėstininkais, artilerija, aviacija užmegzti ir savo pačių koviniams ịsakymams parengti. Šiuo atveju taip pat dažnai buvo pamirštama aptarti tankų veiklos suderinamumą su pèstininkų, ginkluotų sunkiaisiais ginklais, artilerija ir kitų rūšių pajègų veiksmais. Tokie aplaidūs ar skuboti sprendimai per pratybas baigdavosi nesusipratimais kovos lauke. Pavyzdžiui, tankai pradẻdavo puolimą per vèlai arba nukreipdavo ji $\mathfrak{i}$ tuščią vietą, atakuodavo poziciją, kurią tuo pat metu apšaudydavo savoji artilerija, likdavo atkirsti, kai pionieriai, nespejjus atsitraukti tankams, susprogdindavo tiltus, arba prireikus jiems buvo atsisakoma suteikti paramą pėstininkų sunkiųjų kulkosvaidžių ugnimi.

Tarp kitų planuojant veiksmus pasitaikiusių trūkumų nurodyta, kad dauguma atvejų pratimus atliekančių péstininkų dalinių vadai neklausdavo tankų padalinio vado, kaip geriau būtų galima panaudoti jo kovos mašinas, tačiau kartais viską iki smulkmenų palikdavo pastarojo nuožiūrai arba, atvirkščiai, smulkmeniškai varžydavo jo veiksmus. Turėdamas tai omenyje, karo technikos viršininkas pabrèžè, kad pėstininkų vadai privalo tankų ekipažams (padaliniams) nurodyti aiškius uždavinius ir galutinius sprendimus priimti tik gavę tankų padalinio vado siūlymą dẻl jo kovos vieneto panaudojimo ${ }^{154}$.

Atvejų, kai péstininkų dalinių vadai neatsižvelgè i tankų vadų siūlymus, nesuteikè jiems pakankamai laiko ryšiui su remiamais pėstininkų junginiais užmegzti, žvalgybai atlikti ir tinkamai pasiruošti puolimui, pasitaikè ir per 1937 m. rudens kariuomenès manevrus. Tai, be abejo,

\footnotetext{
152 1936-10-07 Šarvuočių rinktinès vado raportas karo technikos viršininkui, LCVA, f. 828 , ap. 1, b. $109,1.107$.

153 1936-10-24 Karo technikos viršininko pastabos dèl š. m. mokymo Gaižiūnų poligone, $L C V A$, f. 929 , ap. 3, b. 922, 1. 75-75 a. p.

154 Ten pat, 1. 75-76.
} 
neigiamai atsiliepė kovinių užduočių vykdymui ${ }^{155} .1938 \mathrm{~m}$. rudens manevrų metu Šarvuočių rinktinès vadas gen. št. plk. ltn. A. Sidabras ir vèl buvo priverstas atkreipti dėmesị $\mathfrak{i}$ tankų kuopų vadų ir dalinių vadų, kuriems buvo priskirtas kovos mašinų padalinys, bendradarbiavimo trūkumus: pastarieji, duodami įsakymus tankų ekipažams, neklausdavo ju kuopos vado, turinčio šiais klausimais būti pagrindiniu remiamojo dalinio vado patarèju, nuomonès ${ }^{156}$.

Parengus puolimo planą ir atlikus reikiamus parengiamuosius darbus, kitas tankų junginio veiksmų kovinès užduoties vykdymo etapas turèjo būti išeities pozicijos užèmimas ${ }^{157}$. Tai padaryti reikejjo kuo veliau ir iš anksto išžvalgytomis prieigomis, taip pat kuo labiau slepiant nuo priešo, kad tankai arteja (pvz., naudojantis parengiamąja artilerijos ugnimi tankų variklių ǔžesiui užgožti). Bendradarbiaujant su pėstininkais pageidauta, kad tankų išeities riba būtų kuo arčiau pèstininkų išeities pozicijos, tačiau, svarbiausia, kad ji būtų kuo sunkiau nustatoma priešo. Užèmę šią poziciją, tankai turèjo būti išrikiuoti puolimo plane numatyta rikiuote ir rūpestingai užmaskuoti ${ }^{158}$. Pratybų praktika taip pat parodè, kad tankų veiksmų sèkmei būtinam netikètumo efektui pasiekti nereikèjo rinktis išeities ribos per arti priešo, kur kovos mašinas išduotų vien jų variklių ǔžimas ${ }^{159}$.

Svarbiausia tankų ir pėstininkų padalinių bendradarbiavimo sritis vis dèlto buvo bendrai vykdomas puolimas. Šiuo atveju tankai turëjo visais atvejais pirmieji ịsiveržti ị priešo gynybos pozicijas ir, kreipdami savo smūgius $\mathfrak{i}$ iš anksto nustatytas ugniavietes, praskinti kelią pèstininkams ${ }^{160}$. Péstininkai savo ruožtu turèjo saugoti tankus atidžiai stebėdami kovos lauką ir visų pirma sutelkdami savo sunkiųjų ginklų ugnị ị pastebètas priešo ugniavietes, ypač tas, kurios yra jo pozicijos sparnuose ir gilumoje. Svarbiausias pėstininkų uždavinys tuo metu - sunaikinti ar bent

\footnotetext{
155 1937-09-26 Pastabos dèl tankų veikimo 1937 m. rugs. mèn. rudens manevruose, LCVA, f. 929, ap. 3, b. 987, 1. 65-66.

156 1938-09-22 Šarvuočių rinktinès vado raportas karo technikos viršininkui, LCVA, f. 828, ap. 1, b. 179, 1. 49-49 a. p.

${ }^{157}$ Péstininku statutas P-51, II dalis. Kautynès. 2 laida, p. 210.

158 Ten pat, p. 210.

${ }^{159} 1932$ m. Pratimo „Batalionas puolant“VIII-24 nagrinejimas, LCVA, f. 538, ap. 1, b. 11, 1. 24 .

${ }^{160}$ Péstininkų statutas P-51, II dalis. Kautynès. 2 laida, p. 210.
} 
nuslopinti priešo prieštankinius ginklus.

Taip pat pabrèžta, kad pèstininkai turi sekti paskui puolančius tankus tokiu atstumu, kuris leistų jiems nedelsiant ir neleidžiant priešui atsigauti išnaudoti kovos mašinų pasiektus rezultatus ${ }^{161}$. Jei kovos lauke susiklostydavo palankios sąlygos užklupti priešą netikètai, pėstininkai turèjo atakuoti kartu su tankais ir laikydamiesi kuo arčiau jų. Kai atstumas iki priešo didesnis, o vietovè atvira, tankai turi skubiai pulti kaip atskiras junginys ir, jei reikia, šiek tiek atsiplèšę nuo pėstininkų. İsiveržę i ginamą poziciją, jie turi sunaikinti pėstininkams pavojingiausias ugniavietes, kad pastarieji, pasinaudodami tankų padarytomis spragomis, galètų užimti atakuojamą plotą.

Jei matoma, kad tarp tankų ir pėstininkų puolimo metu susidarys per didelis atstumas, neleidžiantis vieniems kitų paremti, ir jei disponuojama daugiau nei vienu tankų vienetu, rekomenduota ị puolimą kovos mašinas leisti dviem junginiais ${ }^{162}$. Antrasis junginys, paskui kurị turejo sekti pèstininkai, judèdamas paskui pirmąji junginį, galèjo dengti jị ugnimi, naikinti ar slopinti jo paliktas ugniavietes ir dar geriau praskinti kelią pèstininkams. Siekiant kuo labiau suderinti tankų ir pėstininkų judejimą, priklausomai nuo atstumo, kurị reikia įveikti, ir vietovès sąlygų, vienu atveju pėstininkai turejjo pradèti puolimą antrajam tankų junginiui važiuojant pro jų išeities ribą, kitu atveju - anksčiau už antrajj (o kartais ir pirmąjị) kovos mašinų junginị, kad tankai galètų pralenkti atakuojančius pèstininkus iš anksto nustatytu atstumu.

Bet kuriuo atveju svarbiausia - kad tankai pradètų veikti priešą savo naikinamąja ugnimi anksčiau nei savieji péstininkai pateks i priešo ugnies užtvarą ir spètų padaryti pakankamai spragų spygliuotos vielos kliūtyse, taip pat sunaikinti péstininkams pavojingiausias ugniavietes ${ }^{163}$.

Šių puolimo procedūrų turèjo būti laikomasi veržiantis tiek prie pirminès, tiek prie eilinių kovinèje užduotyje numatytų puolimo ribų. Tačiau visada svarbiausia tankų užduotis buvo slopinti priešą, kol atakuojamą plotą užims pėstininkai. Pasiekus tikslą, kovos mašinos turèjo saugoti juos nuo kontratakų arba, sustabdžius tolesnị puolimą, pasislèpti už artimiausios priedangos. Puolimo metu tankų igulos privalèjo stebėti,

\footnotetext{
161 Ten pat, p. 210-211.

162 Ten pat, p. 211-212.

163 Ten pat, p. 212-213.
} 
ar už jų slenkančių pėstininkų nesustabdè anksčiau nepastebètos priešo ugniavietès, o jei taip nutiko, grịžti ir pašalinti šią grèsmę arba, pèstininkams ir toliau nejudant iš vietos, grižti prie jų ir gauti naujus nurodymus. Kad geriau aptiktų priešo ugniavietes, tankai puldami turèjo judèti ne tiesia linija, o vingiuodami ị vieną ar kitą pusę $e^{164}$.

Kautynių sąlygomis būtinam, tačiau sunkiai palaikomam ryšiui tarp tankų ir pèstininkų užmegzti patikimiausia priemonè buvo iš anksto nustatyti signalai, rodomi ginklu, vèliavèlèmis ir pan., taip pat asmeninis susižinojimas, jei tarp jų yra nedidelis atstumas. Sutartiniai ženklai apèmè svarbiausias judesio ir krypties pokyčių sąvokas. Taip pat svarbus vaidmuo teko pėstininkų siunčiamiems pasiuntiniams. Kad padètų tankams lengviau rasti priešo ugniavietes, pèstininkai turèjo būti aprūpinti signalinèmis raketomis ir pažymèti aptiktas ugniavietes iššaudami šias raketas jų kryptimi ${ }^{165}$.

Per pratybas ir manevrus poligonuose buvo tobulinami veiksmai aptartąja puolimo tvarka, taip pat geriau nei bet kada atsiskleisdavo problemos, kurios galètų trukdyti sèkmingai bendrai veikti tankų ir pėstininku padaliniams realios kovos sąlygomis. Pavyzdžiui, karo technikos viršininkas $1932 \mathrm{~m}$. inspekcinès apžiūros metu tankų būrio atliktą kovini pratimą, kai jis padarè dvi $30 \mathrm{~m}$ pločio spragas spygliuotos vielos užtvaroje ir sunaikino menamo priešo kulkosvaidžių lizdus, ịvertino patenkinamai, tačiau pažymėjo, kad buvo padaryta klaida atakos pradžioje, paliekant išeities ribą, kadangi vienas iš tankų gerokai anksčiau už likusius pajudejo pirmyn ir taip sudarè priešui patogią galimybę naikinti kovos mašinas pavieniui ${ }^{166}$.

Stebint 1935 m. mokymus Gaižiūnų poligone buvo kritikuojamos tankų igulos ne tik dèl netinkamo išvažiavimo iš išeities pozicijų, nes tada kovos mašinos tapdavo lengvesniu taikiniu artilerijai, bet ir dèl to, kad, atlikdamos taktikos pratimus, per mažai dèmesio kreipe i priešo prieštankinių pabūklų ir artilerijos ugni, savo pionierių paženklintas kliūtis ${ }^{167}$. Taip pat pabrèžta, kad mokymų metu pasitaikę atvejų, kai i priešo ginamą poziciją ìsiveržę tankai pernelyg ilgai joje užsibūdavo - realiomis

\footnotetext{
164 Ten pat, p. 213-214.

165 Ten pat, p. 214.

166 1932-09-13 Karo technikos viršininko įsakymas Nr. 5, LCVA, f. 828, ap. 1, b. 155, 1. 77.

167 1935-12-11 Kariuomenès štabo aplinkraštis Nr. 21, LCVA, f. 929, ap. 3, b. 922, 1. 94.
} 
kovos sąlygomis jiems būtų kilusi sunaikinimo grèsmè $\dot{e}^{168}$. Panašios kritikos sulaukta ir $1936 \mathrm{~m}$. vertinant pratimą, kuri atliekantys tankai rèmé péstininkų pulko puolimą, nurodant, kad pirmieji, atakuodami įtvirtintą poziciją, padare per mažai spragų vielų kliūtyse ir per ilgai važinèjo nedideliame plote ties apkasais, todèl būtų tapę patogiu taikiniu priešo pabūklams ${ }^{169}$. Vertinant tankų veiksmus 1938 m. mokymų metu, pagirtas jų išèjimas iš išeities pozicijos ir atakos pradejjimas dviem viena kitą remiančiomis vilnimis, tačiau tuo pat metu pažymèta, kad, puolant pernelyg siaurame plote, péstininkams nepakako padarytų spragų vielų kliūtyse, o antroji tankų vilnis dar ir pavelavo ${ }^{170}$.

Per $1936 \mathrm{~m}$. pratybas pastebèta, kad pèstininkams ne visuomet pavykdavo išnaudoti tankų puolimo rezultatus, kadangi, pastariesiems esant priešaky ir savo ugnimi slopinant priešą, jie pernelyg lètai judejjo ị priekị, kad užimtų atakuojamą poziciją ${ }^{171}$. Apžvelgdamas šarvuotụjų padalinių pasirodymą 1936 m. pratybose Gaižiūnų poligone, karo technikos viršininkas gen. ltn. K. Popeliučka tankų ir pėstininkų bendrų puolamujų veiksmų kontekste, be kita ko, dar kartą atkreipé dèmesị i šį deramos veiksmų koordinacijos trūkumą: pèstininkai per tankų ataką elgèsi pernelyg pasyviai, per toli buvo atsilikę nuo jų arba liko guleti vietoje ir nesistengė išnaudoti tankų pasiektų rezultatų ${ }^{172}$. Kartu išvadose karo technikos viršininkas pabrěžè, kad reikèjo išmokyti žemesnio rango pèstininkų vadus ir eilinius kareivius veikti itin energingai, kai tankai pradeda savo ataką, jei norima su jų pagalba pralaužti priešo ginamą poziciją. ${ }^{173}$. Savo išvadose dèl 1936 m. manevrų Šarvuočių rinktinès vadas, be kita ko, kategoriškai nurodé, kad puolantys tankai ir pesstininkai nebendradarbiavo ir pasta-

\footnotetext{
168 Ten pat, 1. 94 .

${ }^{169} 1936$ m. Bendros pastabos dèl II-os pèst. divizijos dalių mokymo Gaižiūnų poligone 1936 metų II-me laikotarpyje, LCVA, f. 929, ap. 3, b. 922, 1. 27 a. p.

${ }^{170}$ 1939-03-21 III pèst. divizijos štabo I skyriaus nurodymai 1938 m. Gaižiūnų poligono II-ro laikotarpio mokyme pastebètų trūkumų (paklaidų) pašalinimui bei dalinių ir vadų rengimo reikalu, $L C V A$, f. 929 , ap. 3, b. $1114,1.27$ a. p.

${ }^{171}$ 1936-10-27 Šaudymų ir taktiškų lauko pratimų 1936 metų Gaižiūnų poligono I-me laikotarpyje išdavos, LCVA, f. 509, ap. 1, b. 321, 1. 27.

172 1936-10-24 Karo technikos viršininko pastabos dèl š. m. mokymo Gaižiūnų poligone, LCVA, f. 929, ap. 3, b. $922,1.75$ a. p.

173 Ten pat, 1. 76 .
} 
rieji visai nerèmė tankų ugnimi ${ }^{174}$. Taip pat griežtai gen. št. plk. ltn. A. Sidabras įvertino péstininkų ir tankų kovinį bendradarbiavimą $1937 \mathrm{~m}$. pratybose, teigdamas, kad ị tai visai nebuvo kreipiama dèmesio, ir pažymèdamas, kad karo metu tai galètų turèti skaudžių padarinių ${ }^{175}$.

Kaip parodè vienas iš $1936 \mathrm{~m}$. pratybų pratimų, kuri atliekant pėstininkų bataliono veiksmus rèmè vienas tankų būrys, tankų puolimo momento parinkimas priklausè nuo remiamojo pėstininkų dalinio, o ne nuo kovos mašinų junginio vado. Bataliono vadui nurodžius pačiam tankų būrio vadui pasirinkti puolimo laiką, pastarasis, negalèdamas sekti ịvykių eigos visame bataliono veiklos bare, praleido patogų pulti momentą ${ }^{176} \cdot \mathrm{Pa}$ vyzdžiui, per vienas iš 1937 m. pratybų, vykdant užduotị, prieš tai nesuderinus bendrų veiksmų su tankais, pėstininkai jiems skirtą užimti objektą puolè anksčiau, nei buvo ịsakyta, ir be juos remti turëjusių tankų būrio. Tankų būrio vadas, pastebėjęs prie priešo priartejjusius savo pèstininkus, savo iniciatyva organizavo puolimo veiksmus jiems paremti, tačiau su padaliniu atvyko pavèlavęs - priešas jau buvo spejjęs palikti pozicijas ${ }^{177}$.

Bendrų péstininkų ir tankų veiksmų teorinių pagrindų dėstymas Pėstininkų statute baigiamas tankų panaudojimo ypatingomis - miško ir gyvenvietès - sąlygomis aptarimu ${ }^{178}$. Tankų veiksmų šiose vietovèse principai, susiję su, pvz., galimų kovinių užduočių pobūdžiu ir apribojimais, buvo abiem atvejais beveik vienodi. Veikiantys miškingoje ir apgyvendintoje vietoveje tankai visų pirma negalejo laisvai manevruoti (ypač didesniu greičiu) ir laiku pastebèti grèsmių, bet priešui buvo patogu juos užklupti netikètai ir iš arti. Dẻl šios priežasties dar svarbesnè tapo savo pėstininkų, turejjusių laiku pastebèti gresiantị pavojų, apie ji pranešti tankų iguloms ir taip juos apsaugoti, parama ${ }^{179}$. Nepaisant išvardytų sunkumų, statute laikytasi nuomonès, kad tankai šiomis kovos sąlygomis gali

174 1936-10-07 Šarvuočių rinktinès vado raportas karo technikos viršininkui, LCVA, f. 828 , ap. 1, b. $109,1.107$.

175 1937-09-30 Šarvuočių rinktinès vado raportas karo technikos viršininkui, LCVA, f. 929 , ap. 3, b. $987,1.58$.

${ }^{176} 1936$ m. Bendros pastabos dèl II-os pèst. divizijos dalių mokymo Gaižiūnų poligone 1936 metų II-me laikotarpyje, LCVA, f. 929, ap. 3, b. 922, 1. 24 a. p.

1771937 m. Raudonųu ų pusès l. tankų būrio vado pastabos, LCVA, f. 929, ap. 3, b. 987, 1. 68 a.p.

${ }^{178}$ Péstininku statutas P-51, II dalis. Kautynès. 2 laida, p. 214-216.

179 Ten pat, p. $214-216$. 
būti labai naudingi, kadangi pajègtų bent iš dalies pavaduoti artileriją, kuriai veikti minètomis aplinkybèmis būtų buvę sunku ${ }^{180}$. Pirminè kovos mašinų užduotis aptariamaisiais atvejais buvo padèti péstininkams užimti pamiškes ar gyvenviečių pakraščius. Pažymètina, kad kovos veiksmams vykstant miške ar gyvenvieteje, tankai, priešingai nei veikdami atviresnèje vietovèje, nebeturèjo veržtis ị priekí, aplenkdami pèstininkus, o lètai judèti paskui priešakinius jų junginius ir taip padèti užimti artimiausius pasipriešinimo taškus. Šiose vietovèse veikiantys tankų padaliniai taip pat, skirtingai nei nurodoma bendrosiose nuostatose, galëjo būti skaidomi ir priskiriami remiamam pèstininkų junginiui skyriais ( $\mathrm{du}$ tankai) arba jam priskiriamos net pavienès mašinos. Be to, tankai galëjo būti sèkmingai panaudoti ir remiant miškingoje ar apgyvendintoje vietovejje ịsitvirtinusio priešo pozicijų apèjimo manevrą ${ }^{181}$.

Panašių i čia aptartas įžvalgų tankų ir pėstininkų padalinių kovinio bendradarbiavimo tema galime pastebetti ir aptariamojo laikotarpio karineje spaudoje. Savo straipsniuose Lietuvos karininkai taip pat akcentavo detalaus kovinès užduoties planavimo, glaudaus bendradarbiavimo kovos lauke, efektyvios tarpusavio paramos ugnimi būtinybę, siekiant sẻkmingų péstininkų ir jiems svarbių paramos ginklų - tankų bendrų veiksmų ${ }^{182}$.

\subsection{Tankų padalinių ir kavalerijos bendradarbiavimas}

Be paramos péstininkams, kita ne mažiau svarbi tankų padalinių užduotis karinio konflikto atveju būtų buvusi parama antrajai manevrinei Lietuvos kariuomenès ginklo rūšiai - kavalerijai. Šio kovinio bendradarbiavimo pagrindai yra išdèstyti Kavalerijos statuto antrojoje dalyje apie kautynes ${ }^{183}$. Šiame kontekste, kaip ir kalbant apie pestininkų veiksmus, visų pirma primenama, kad, nepaisant tankų ir kitų šarvuotųjų kovos mašinų teikiamos naudos vykdant kovines užduotis, jos yra tik pagalbinė

\footnotetext{
180 Ten pat, p. 214.

181 Ten pat, p. 214-216.

${ }^{182}$ Gen. št. plk. ltn. Grinius, Tankų ir pèstininkų bendradarbiavimas, Mūsų žinynas, Nr. 109, Kaunas, 1934, p. 310-326; Nr. 110, Kaunas, 1934, p. 419-433; J. ltn. Pečiūra, Tankų bendradarbiavimas su kitomis ginklų rūšimis, Mūsų žinynas, Nr. 128, Kaunas, 1935, p. 437-440.

${ }^{183}$ Kavalerijos statutas K-51, II dalis. Kautynès, p. 75-88.
} 
priemonė, kuriai dèl ịvairių priežasčių negalint dalyvauti kautynėse, kavaleristai turi gebėti įvykdyti skirtą užduotị ir be jų pagalbos ${ }^{184}$.

Šarvuotosioms kovos mašinoms, dalyvaujančioms veiksmuose kartu su raitininkais, buvo numatytos šios kovinès užduotys: 1) su kavalerijos veiksmais suderinti netikèti ir staigūs smūgiai, 2) savarankiškas svarbių ribų užèmimas, jei numatyta, kad savi raitininkai atvyks greitai, 3) savarankiška žvalgyba, 4) parama kavalerijai žvalgyboje ir saugoje, 5) tiesioginė parama kavalerijai kautynių metu, 6) pasalos ir netikèti smūgiai, 7) kavalerijos atsitraukimo priedanga, 8) priešo apsupimas ir jo atsitraukimo kelių atkirtimas, 9) kova su priešo šarvuotosiomis kovos mašinomis.

Greitų lengvųjų tankų kavalerijai teikiama svaria parama neabejojo ir Lietuvos kariuomenès karininkai, pabrèžiantys, kad tankai gali tapti galinga raitininkų smūgio priešui priemone ir, užtikrinus glaudų bendradarbiavimą, gerokai sustiprinti jų veiksmingumą atliekant kone visų tipụ kovines užduotis ${ }^{185}$.

Konkrečias užduotis tankų junginiui turèjo skirti kavalerijos dalinio, kuriam jis priskirtas, vadas, prieš tai turejjęs išklausyti tankų padalinio vado siūlymą dèl kovos mašinų panaudojimo ir leisti jam laisvai pasirinkti užduoties vykdymo būdą. Nepriklausomai nuo užduoties pobūdžio, ją vykdant buvo labai svarbu, kad raitininkai: 1) sudarytų su tankais aiškų veiksmų planą ir palaikytų ryšius, 2) paremtų tankų puolimą, savo sunkiųjų ginklų ugnị nukreipdami ị priešo prieštankinius pabūklus ir kulkosvaidžius, 3) naudotų tankus tinkamoje jiems veikti vietovejje, 4) teiktų kovos mašinoms inžinerinę paramą, 5) neskaidytų tankų junginio smulkiomis dalimis, o naudotų sutelktus ${ }^{186}$.

Daugelis kovinio tankų ir kavalerijos bendradarbiavimo bendrųjų principų buvo beveik tokie pat kaip ir jų veiksmų su pėstininkais. Pavyzdžiui, kovos mašinos turèjo padèti raitininkams laimèti savo ugnimi ir svoriu naikindamos priešo gyvąją jègą, sunkiąją ginkluotę, ịtvirtinimus, o ịtraukiant jas ị kautynes, visada siekti kuo didesnio netikètumo efek-

\footnotetext{
184 Ten pat, p. 75.

185 Ten pat, p. 77-78; J. ltn. Pečiūra, Tankų bendradarbiavimas su kitomis ginklų rūšimis, Mūsų žinynas, Nr. 128, p. 441; Ltn. Ingaunis, Kavalerijos bendradarbiavimas su motomechanizuotais daliniais, Mūsuz žinynas, Nr. 134, Kaunas, 1936, p. 453-461.

${ }^{186}$ Kavalerijos statutas K-51, II dalis. Kautynès, p. 77-78.
} 
to $^{187}$. Kavalerijos pulkui paprastai būdavo priskirtas vienas tankų būrys (pagrindinis kovinių užduočių vykdymo vienetas), o išskirtiniais atvejais - visa kuopa, kurios vadas, kaip ir bendradarbiaujant su pėstininkais, turejo tapti pagrindiniu raitininkų vado patareju dèl tankų panaudojimo ir palaikyti ryši su savo būriais, taip pat rūpintis logistikos klausimais. Turimi tankai, kurių buvo palyginti nedaug, beveik visada naudoti būtent pagrindine kovos veiksmų kryptimi, siekiant veiksmų efektyvumo ir kartu taupyti kovos mašinų techninius ir degalų išteklius ${ }^{188}$.

Tai, kaip parode pratybos, nebuvo taip paprasta, kadangi nepakankamai gerai tankų kovinio panaudojimo pagrindus išmanantys kavalerijos ir péstininkų vadai buvo linkę jais remtis ir tada, kai tam nebūdavo jokios būtinybès. Negana to, šios technikos ir taktikos žinių spragos lemdavo ir netinkamus sprendimus parenkant tankams užduotis ar veikimo vietoves (dèl šių klaidų igulos nariai patirdavo traumų atsitrenkę $\mathfrak{i}$ kovos mašinos vidaus sieneles ir prietaisus) arba netikslingai juos paskirstant (pvz., tankų būrys priskiriamas kavalerijos ar pèstininkų būriui) ${ }^{189}$.

Pasibaigus 1936 m. kariuomenès manevrams, Šarvuočių rinktinės vadas, ragindamas tankus pratybų metu naudoti ekonomiškiau ir racionaliau, pažymėjo, kad kai kurie jų per visus tų metų mokymus nuvažiavo po $1000 \mathrm{~km}^{190}$. Vertinant tankų veiksmus per $1937 \mathrm{~m}$. pratybas pastebèta, kad kavalerijos vadai perdetai siekè per trumpą laiką panaudoti šias kovos mašinas kone visomis veiksmų kryptimis, kartais net gerokai viena nuo kitos nutolusiomis, taip pat aplinkybèmis, kuriomis jie negalètų duoti apčiuopiamos naudos, o tik taptų labiau pažeidžiami ${ }^{191}$. Tiesa, per $1937 \mathrm{~m}$. manevrus tankai vidutiniškai nuvažiavo po $150-215 \mathrm{~km}^{192}$. Nepaisant šių

\footnotetext{
187 Ten pat, p. 80 .

188 Ten pat, p. $80-81$.

189 1936-10-07 Šarvuočių rinktinès vado raportas karo technikos viršininkui, LCVA, f. 828 , ap. 1, b. 109, 1. 107; 1936-10-24 Karo technikos viršininko pastabos dèl š. m. mokymo Gaižiūnų poligone, LCVA, f. 929, ap. 3, b. 922, 1.75 a. p.; 1937-09-30 Šarvuočių rinktinès vado raportas karo technikos viršininkui, $L C V A$, f. 929, ap. 3, b. 987, 1. 58.

190 1936-10-07 Šarvuočių rinktinès vado raportas karo technikos viršininkui, LCVA, f. 828 , ap. 1, b. $109,1.107$.

${ }^{191}$ 1937-09-26 Pastabos dèl tankų veiksmų 1937 m. rugs. mèn. rudens manevruose, LCVA, f. 929, ap. 3, b. 987, 1. 64 a. p., 66.

1921937 m. Raudonųjų pusèje prie lengvų tankų būrio tarpininko pastabos, LCVA, f. 929, ap. 3, b. 987, 1. 62; 1937 m. Raudonųjų pusei l. tankų būrio vado pastabos, LCVA, f. 929,
} 
trūkumų, tiek 1936 m., tiek 1937 m. manevrai parodè, kad tankų veiksmai su kavalerija yra sklandesni ir geresni, nei su pėstininkais, o vikšrinès šarvuotosios kovos mašinos dèl savo manevringumo nelygioje vietoveje ir nepriklausymo nuo kelių tinklo (priešingai nei kariuomenès ratiniai šarvuočiai) buvo rimta parama raitininkams ir pelnè jų vadų aukštą įvertinimą ${ }^{193}$.

Palyginti didelis Lietuvos kariuomenès lengvụjų tankų VCL greitis ir mobilumas raižytoje vietoveje lèmè, kad jie bene vieninteliai iš šarvuotosios technikos vienetų galejjo sklandžiai veikti kartu su raitininkais, taip pat ir žvalgyboje, priešakineje ir užnugario saugoje. Tokiu atveju jie turejjo ieiti ị žvalgybos raitelių rinktinès sudètị ir dažniausiai laikytis jos tvarkos branduolyje, kad galètų stoti ị kautynes tik tada, kai pagal aplinkybes reikètų siųsti ị kovą pagrindines žvalgybos rinktinès pajėgas. Savarankiškus žvalgomuosius ar puolamuosius tankų veiksmus buvo numatyta vykdyti tik nedideliu atstumu nuo likusių žvalgų pajègų, kad pastarieji galètų juos greitai paremti ${ }^{194}$. Tiesa, vertinant $1937 \mathrm{~m}$. kariuomenès manevrus atkreiptas dėmesys, kad žvalgyboje, kaip ir kitais atvejais, dera šias kovos mašinas naudoti tikslingai, apgalvotai ir nerizikuoti be reikalo jas pademonstruoti priešininkui siunčiant atlikti tokių užduočių, kurias galima patikèti ir vieniems raitiesiems žvalgams ${ }^{195}$. Tuo pat metu tankai pasirodè esą naudingi priešakinejje saugoje šalinant iš kelio smulkesnes priešo grupes (tik tuo atveju, jei veikiama šviesiu paros metu ir judama kolonos priešakyje), kurios, net ir nedidelès, pajėgdavo sustabdyti ir gaišinti žygio vorą, kurios priešakyje judèjo ne tankai, o, pvz., motorizuotieji pėstininkai ${ }^{196}$.

Puolamosiose ir pasitinkamosiose kautynèse tankai turèjo veikti pagrindinio smūgio kryptimi arba atlikti manevrus, nukreiptus i priešo sparną bei užnugarị, savarankiškai arba tai pačiai užduočiai skirto kavalerijos ar motorizuotųjų pėstininkų dalinio sudètyje. Atsižvelgiant $\mathfrak{i}$

ap. 3, b. $987,1.69$.

193 1936-10-24 Karo technikos viršininko pastabos dèl š. m. mokymo Gaižiūnų poligone, LCVA, f. 929, ap. 3, b. 922, 1. 75 a. p.; 1937-09-26 Šarvuočių rinktinès raštvedžio-iždininko raportas ūkio viršininkui, $L C V A$, f. 929 , ap. 3, b. $987,1.67$ a. p.

${ }^{194}$ Kavalerijos statutas K-51, II dalis. Kautynès, p. 81-82.

1951937 m. Šarvuočių rinktinès vado pastabos dèl šių metų kariuomenės manevruose IX. 12-IX. 18 d. d. tankų ir šarv. automobilių naudojimo ir jų veikimo, LCVA, f. 929, ap. 3, b $987,1.59$ a. p.

${ }^{196} 1937$ m. Raudonụjų pusès 1 . tankų būrio vado pastabos, LCVA, f. 929, ap. 3, b. 987, 1. 68 . 
didesnę raitininkų veiksmų spartą, Kavalerijos statute taip pat pabrèžta, kad iš tankų ir jų vadų, bendradarbiaujančių su kavalerija, irgi laukta atitinkamai operatyvių veiksmų, iniciatyvos, gebos greitai orientuotis pagal situaciją ir priimti racionalius sprendimus ${ }^{197}$.

Padedant tankams sutelktojo smūgio i̇ priešo sparną ir užnugarị potencialą gerai atskleidè vienas $1936 \mathrm{~m}$. rudens manevrų epizodas ${ }^{198}$. Rugsèjo $24 \mathrm{~d}$. vadinamiesiems "mèlyniesiems“ atstovavęs 1-asis husarų pulkas su jị remiančiu lengvųjų tankų būriu iš užnugario puolẻ „raudonųjų“ dešiniajame sparne stovintị pèstininkų batalioną ir jị visiškai sunaikino, be to, paėmè „ị nelaisvę“ daug jo karių ir ịrangos. Negana to, kad pulta bene labiausiai pažeidžiama karinio dalinio pusė, raitelių ir tankų ataka buvo gerai tarpusavyje suderinta, netikèta ir staigi, o kovos mašinos veikè labai joms patogioje vietoveje. Tankams taip pat pavyko išlaikyti didelị bendro veikimo su kavalerija tempą, igyvendinti raitininkų vadų pageidavimą per 15-20 min. sèkmingai sudalyvauti trijuose puolimuose ir írodyti savo, kaip paramos ginklo, vertę ${ }^{199} .1937 \mathrm{~m}$. vèl sèkmingai pasirodyta, kai per manevrus, rugsèjo 16 d., ši kartą jau „raudonųjų“ kavalerijos eskadronui, remiamam tankų būrio, pavyko sumušti ir priversti, patyrus daug nuostolių, atsitraukti „mèlynųjų“ pajègas ${ }^{200}$. Tankai šioje atakoje ir vèl veikè labai gerai, kadangi ị kautynes ịsitraukè staiga ir netikètai, o juc puolimas buvo nukreiptas i priešo užnugarị ir suderintas su pėsčiomis puolančiais raitininkais ${ }^{201}$.

Iprastinès bendro kavalerijos ir tankų puolimo procedūros, seka ir principai iš esmès nesiskyrè nuo anksčiau aptartų nustatytų bendradarbiavimo su pèstininkais principų, kadangi raitininkai taip pat beveik visada ì kovą turejo stoti kaip pėstininkai, nes žirgai pirmiausia buvo jų transporto priemonè. Buvo tikimasi, kad kavalerijos dalinio ir ji remiančio tankų junginio vadai sudarys detalų planuojamo puolimo planą,

\footnotetext{
${ }^{197}$ Kavalerijos statutas K-51, II dalis. Kautynès, p. 82.

1981936 m. Kariuomenès manevruose tankeliams „mèlynųjų“ pusèje duoti uždaviniai, uždavinius vykdant pastebèti netikslumai ir bendros pastabos manevruose, $L C V A, \mathrm{f} .828$, ap. 1, b. 109, 1. 101 a. p.

199 Ten pat, 1. 101 a. p. - 102.

${ }^{200} 1937 \mathrm{~m}$. Raudonųjų pusejje prie lengvų tankų būrio tarpininko pastabos, LCVA, f. 929, ap. 3, b. $987,1.61$ a. p.

201 Ten pat, 1. 61 .
} 
numatantị, be kita ko, tarpusavio paramą ugnimi, siektinus tikslus, suderinantị puolimo tvarką, laiką ir ryšius. Tam reikejjo, kad tankų padalinio vadas galètų išžvalgyti būsimąji kovos lauką ir turètų progą pateikti raitininkų vadui savo siūlymus dèl kovos mašinų geriausio panaudojimo, prieš pastarajam priimant galutinị sprendimą. Po to, kaip ịprasta, tankai turèjo kuo slapčiau užimti išeities ribos poziciją, kuri taip pat turejjo būti parinkta kuo geriau juos dengiančioje vietovejje ${ }^{202}$.

Kaip ir veikiant su pėstininkais, bendradarbiaujant su kavalerija ne visada buvo laikomasi šių nuostatų. Pavyzdžiui, 1936 m. rudens manevrų metu, rugsejjo 23 d., kavalerijos dalinio vado ịsakymu tankų būrys buvo du kartus pasiųstas $\mathfrak{i}$ skubotas atakas. Antrosios atakos metu dvi kovos mašinos buvo išvestos iš rikiuotès ${ }^{203}$. Šias atakas siejo tai, kad raitininkų vadas abiem atvejais dave įsakymą pulti visiškai nesuteikęs tankų būrio vadui laiko išžvalgyti vietovei, kurioje teks veikti, ir priešo pajègumams, negana to, pats neturejo tikslių žinių apie priešo dispoziciją, jo karių skaičių ir pajègumą. Toks skubotumas, vertęs tankų padalinius veikti neišžvalgytoje vietoveje ir atakuoti priešą, kurio žinoma tik buvimo vieta, buvo įvertintas kaip pernelyg rizikingas tikros kovos sąlygomis ${ }^{204}$. Dalinis kovinis įsakymas, pateiktas neišklausius tankų padalinio vado pasiūlymo, kuriame konkrečiai nenurodoma kovinè užduotis, puolimo kryptys ir susirinkimo vieta, sumažino tankų junginio galimybes tinkamai atlikti užduotị. Be to, skubotas įsakymas, neleidžiantis ne tik atlikti žvalgybos, bet ir tankų junginio vadui supažindinti savo igulų su jo turiniu, padare visą kovos mašinų padalini pernelyg priklausomą nuo savo vado ${ }^{205}$. Vieno iš 1936 m. pratybose dalyvavusių tankų būrių vadas paminèjo tokią ataką, kai, raitininkų vadui davus skubotą ịsakymą dèl aiškiai neatpažinto priešo puolimo, galiausiai paaiškejjo, kad tai tebuvo menkas jo vienetas, su kuriuo lengvai galejo susitvarkyti vieni raiteliai ${ }^{206}$. Negana to, šio puolimo metu

\footnotetext{
${ }^{202}$ Kavalerijos statutas K-51, II dalis. Kautynès, p. 82-83.

${ }^{203} 1937$ m. Kariuomenès manevruose tankeliams „mèlynujuc“ pusèje duoti uždaviniai, uždavinius vykdant pastebėti netikslumai ir bendros pastabos manevruose, $L C V A$, f. 828, ap. 1, b. 109, 1. 101-101 a. p.

204 Ten pat, 1. 101-102; 1936-10-07 Šarvuočių rinktinės vado raportas karo technikos viršininkui, f. 828, ap. 1, b. 109, 1. 107.

${ }^{205} 1937$ m. Mèlynųjų tankų būrio vado pastabos dèl kariuomenès manevrų, LCVA, f. 828, ap. 1, b. 109, 1. 103.
}

206 Ten pat, 1. 103. 
sugedus būrio vado tankui, likusios kovos mašinos, ekipažams nežinant, kur yra susirinkimo vieta, ilgokai sukiojosi kovos lauke aplink būrio vadą, kol jis įsèdo ị kitą tanką. Kitą kartą tankų būrio vadui nurodè, o ne leido pačiam pasirinkti išeities ribą, kuri pasirodè esanti per arti priešo, o prieigos - gerai matomos, taigi nebuvo galimybès tankų panaudoti netikètai ${ }^{207}$.

Iprastinių, bendrų kavalerijos, veikiančios pėsčiojoje rikiuoteje, ir tankų puolamųjų veiksmų principai buvo praktiškai tokie pat kaip ir tankų padalinių bendradarbiavimo su pèstininkais gairès. Pagrindiniai tokio puolimo akcentai, kaip jau aptarta, buvo šie: 1) tankai turejjo pradèti veikti priešą naikinamąja ugnimi anksčiau, nei raitininkai pateks i jo ugnies užtvarą, 2) tankai privalèjo pirmieji ịsiveržti ị priešo poziciją, padaryti spragas vielų kliūtyse ir slopinti jo pasipriešinimą, kol atakuojamą objektą užims raitininkai, 3) puolimo metu raitininkai turẻjo saugoti ir remti tankus ugnimi, laikytis už jų tokiu atstumu, kuris, susiklosčius palankioms aplinkybėms, leistų nedelsiant išnaudoti tankų atakos rezultatus ${ }^{208}$. Ryšių tarp kavalerijos ir tankų padalinių kautynių metu užmezgimo ir palaikymo būdai bei bendri šių pajègų rūšių veiksmai miškingoje ar apgyvendintoje vietovejje taip pat nesiskyrè nuo analogiškų dalykų, numatytų tankams veikiant su pèstininkais ${ }^{209}$.

Susiklosčius tam tikroms aplinkybèms, tankams galejjo tekti remti ir specifinị kavalerijos puolimo būdą - raitąją ataką. Padèti raitininkams sèkmingai užbaigti šị veiksmą (dèl būtino didelio greičio tai galèjo padaryti, ko gero, tik „Vickers“ kovos mašinos) tankai galëjo dviem būdais: visu greičiu verždamiesi kavalerijos priešakyje arba savarankiškai smogdami $\mathfrak{i}$ priešo sparną ${ }^{210}$. Bet kuriuo atveju jie privalejo atakuoti priešą pirmieji ir sutrikdyti jo pasipriešinimą, kol raiti kavaleristai galès pasiekti jị savo kardais. Atakai pavykus, tankai pirmieji ir nelaukdami kavalerijos turejo imtis persekioti priešą arba saugoti jos sparnus nuo kontratakų. Persekiojant tankų užduotis buvo nublokšti priešą tolyn ir neleisti jam persigrupuoti ${ }^{211}$.

Per 1937 m. kariuomenès manevrus buvo pademonstruota, kokių rezultatų galima pasiekti sèkmingai organizavus persekiojimą (tiesa,

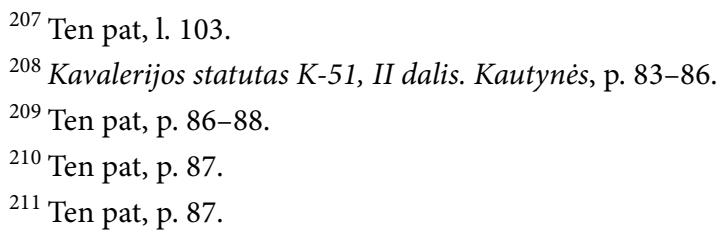


veikiant kartu su pėstininkais), kai, vieniems pėstininkams sėkmingai nubloškus priešą, $1,5 \mathrm{~km}$ ji persekiojusiems tankams pavyko išplèsti užimtos teritorijos ribas ${ }^{212}$.

Gynybinèse kovose tankai turejjo tapti besiginančio dalinio rezervu ir neleisti priešui prasiveržti, o stabdomosiose kautynèse jų užduotis buvo paremti staigius, riboto masto puolimus, kuriais siekiama sustabdyti ar sutrikdyti priešo veržimąsi i priekį, arba dengti kitų stabdančiųjų padalinių atitrūkimo nuo priešo veiksmus. Šiose kovose tankų reikšmẻ dar labiau padidèdavo, jei dalinio, kurio sudètyje jie veikè, gynybos ribos būdavo plačios ${ }^{213}$.

1937 m. kariuomenès manevrai suteikè ne vieną progą patikrinti tankų efektyvumą stabdomosiose kovose. Vertinant šias pratybas buvo pabrèžta, kad dèl puolančio priešo prieštankinių pabūklų grèsmès stabdant, atitrūkimo nuo priešo veiksmams paremti tankai turi būti naudojami tik tuomet, kai kyla grèsmé, jog atitrūkti méginantis padalinys nesugebės to padaryti savo jẻgomis ${ }^{214}$. Taip nutiko šių manevrų metu, rugsejjo 16 d., kai tankų būrys padejo atitrūkti atskirai veikusiam ir stipresnio priešo spaudžiamam kavalerijos eskadronui, kuriam vienam būtų buvę labai sunku tai padaryti ${ }^{215}$. Kita svarbi tankų užduotis stabdomosiose kautynėse buvo dengti savo dalinio sparnus ir kontratakuoti, priešui mėginant ji apsup$\mathrm{ti}^{216} .1937 \mathrm{~m}$. manevrai taip pat pateike kelis sèkmingo tankų panaudojimo kontratakose, kuriomis siekta neleisti priešo pajègoms apsupti savo dalinių ar atkirsti jiems atsitraukimo kelių, pavyzdžių, ịrodžiusių tankų tinkamumą ir vertę šiose kritinèse situacijose ${ }^{217}$.

2121937 m. Raudonųjų pusèje prie lengvų tankų būrio tarpininko pastabos, LCVA, f. 929, ap. 3, b. $987,1.61$ a. p.

${ }^{213}$ Kavalerijos statutas K-51, II dalis. Kautynès, p. 87.

2141937 m. Šarvuočių rinktinès vado pastabos dèl šių metų kariuomenès manevruose IX. 12-IX. 18 d. d. tankų ir šarv. automobilių naudojimo ir jų veikimo, LCVA, f. 929, ap. 3, b. 987, 1. 59; 19370926 Pastabos dèl tankų veikimo 1937 m. rugs. mèn. rudens manevruose, $L C V A$, f. 929 , ap. 3, b. $987,1.64$ a. p.

${ }^{215} 1937 \mathrm{~m}$. Raudonųjų pusejje prie lengvų tankų būrio tarpininko pastabos, LCVA, f. 929, ap. 3, b. $987,1.61$ a. p.

${ }^{216}$ 1937-09-26 Pastabos dèl tankų veikimo 1937 m. rugs. mėn. rudens manevruose, LCVA, f. 929, ap. 3, b. 987, 1. 65.

${ }^{217} 1937$ m. Šarvuočių rinktinès vado pastabos dèl šių metų kariuomenès manevruose IX. 12-IX. 18 d. d. tankų ir šarv. automobilių naudojimo ir jų veikimo, LCVA, f. 929, ap. 3, 


\subsection{Tankų padalinių bendradarbiavimas su artilerija}

Paskutinè sudedamoji tankų padalinių bendradarbiavimo kovos lauke su pagrindinèmis Lietuvos kariuomenès ginklų rūšimis dalis buvo jų sąveika su artilerija. Šios sąveikos teoriniai principai buvo išdèstyti Artilerijos statute ${ }^{218}$. Kad galètų sèkmingai įvykdyti skirtas užduotis, remiančiosios artilerijos vadas turèjo atitinkamu laiku gauti aiškius tankų padalinio vado nurodymus ir žinoti: 1) savo tankų savybes ir jų ženklus, 2) tankų užduotis ir kurie priešo gynybiniai įrenginiai gali jiems trukdyti, 3) tankų išeities ribą, judejjimo kryptị ir susirinkimo vietą, 4) atsitraukimo kryptị nepavykus sẻkmingai baigti užduoties, 5) tankų sutartinius ženklus ugniai paleisti arba nutraukti ir taikiniams nurodyti ${ }^{219}$. Tankų naudai visų pirma veikè artilerijos, priskirtos viso péstininkų ar kavalerijos dalinio (kuriam ir priklausè kovos mašinos) kovos veiksmams paremti, parengimas būsimai atakai. Šios priešo pozicijos apšaudymo prieš puolimą (artilerinio parengimo) procedūros baigiamojoje dalyje artilerija turèjo nukreipti savo ugnị i priešo stebejjimo postus ir spejjamas prieštankinių pabūklų ugniavietes. Taip pat dūminiais sviediniais tuo pat metu priešais stebejjimo postus ir spejjamas prieštankinių pabūklų pozicijas galèjo būti padaroma dūmų uždanga ${ }^{220}$. Šie veiksmai turèjo sutrukdyti priešui apšaudyti puolančius tankus prieštankine ugnimi ir nutaikyti i juos savo artileriją. Tankams atakuojant priešo poziciją, užduotis naikinti pasirodančius jo prieštankinius pabūklus turejjo tekti atskiroms artilerijos baterijoms, tiesiogiai priskirtoms tankų puolimui remti ${ }^{221}$. Šios baterijos turèjo iš anksto nustatytuose veikimo baruose įrengti stebejjimo postus ir paruošti šaudymo ị spejjamas prieštankinių pabūklų vietas duomenis. Tankams pasiekus iš antžeminių artilerijos stebëjimo postų nematomą ribą, šių atskirųjų baterijų paramos kovos mašinoms užduotis būdavo įvykdyta, ir jos vèl tapdavo tiesiogiai pavaldžios savo artilerijos dalinio vadui ${ }^{222}$. Be to,

b. 987, 1. 59; 1937-09-26 Pastabos dèl tankų veikimo 1937 m. rugs. mèn. rudens manevruose, $L C V A$, f. 929 , ap. 3, b. $987,1.64$ a. p.

${ }^{218}$ Artilerijos statutas A-51, II dalis. Kautynès, p. 161-162.

219 Ten pat, p. 161-162.

${ }^{220}$ Ten pat, p. $161-162$.

${ }^{221}$ Ten pat, p. 161-162.

222 Ten pat, p. 162. 
dalyvaujantys kautynèse tankai galèjo bent iš dalies pavaduoti artileriją ir atlikti tam tikras ugnies paramos manevriniams daliniams užduotis, ir tokiu būdu leisti artileristams labiau sutelkti paramą tankams ${ }^{223}$. Tiesa, sklandus ir tikslus tankų ir artilerijos padalinių bendradarbiavimas manevrų ir pratybų metu pasirode esąs sunkiai iggyvendinama užduotis. Vertindami 1935, 1936 ir 1937 m. mokymus, aukšto rango kariuomenès karininkai konstatavo, kad ši sritis gerokai apleista: tankų ir artilerijos vienetų bendradarbiavimui nebuvo skiriama deramo dèmesio, tankų atakų parama artilerijos ugnimi iki galo neaptarta ir dažnai apskritai nevykdoma ${ }^{224}$.

Tankų ginkluote, jos naudojimo principai ir taktika buvo šių kovos mašinų kovinio pajėgumo ir kartu jų vaidmens planuojamuose kovos veiksmuose pagrindas. Lietuvos kariuomenès tankų pagrindinė ginkluotè, leidusi veiksmingai kovoti tik su priešo gyvąja jèga ir sunkiąja ginkluote, bet ne su šarvuotąja technika, ir tai, kad šios karo technikos vienetų turèta palyginti nedaug, lèmé, kad tankus buvo numatyta naudoti (ir jų igulos atitinkamai tam ruoštos) kaip pagrindinių manevrinių ginklų rūšių pagalbinę priemonę. Nepaisant tokio iš pirmo žvilgsnio riboto vaidmens, šios tankų teikiamos paramos kovinių veiksmų metu svarba kariuomeneje buvo suprantama ir jų pagalba vertinama. Buvo siekiama, kad pèstininkai, kavalerija, tankai ir artilerija sudarytų vieningai, darniai veikiantị kovinị vienetą, kurio sudètyje esantys atskirų sausumos pajègų rūšių elementai remtų ir stiprintų vienas kitą. Kariuomenès manevrai ir pratybos aiškiai parodè, kad sklandus bendradarbiavimas kovos lauke yra sunkus darbas, kuriam reikia tinkamai pasirengti, o jo detales tarpusavyje suderinti ir nuosekliai tobulinti atitinkamas kompetencijas. Nepaisant klaidų, kariuomenès pratybose ne kartą ịsitikinta, kad tinkamai naudojami tankai gali tapti rimta paspirtimi ar net kovinès užduoties sèkmę lemiančiu veiksniu.

\footnotetext{
${ }^{223}$ J. ltn. Pečiūra, Tankų bendradarbiavimas su kitomis ginklų rūšimis, Mūsų žinynas, Nr. 128, p. 440-441.

224 1935-12-11 Kariuomenès štabo aplinkraštis Nr. 21, LCVA, f. 929, ap. 3, b. 922, 1. 95; 1936-10-07 Šarvuočių rinktinès vado raportas karo technikos viršininkui, $L C V A$, f. 828, ap. 1, b. 109, 1. 107; 1936-10-24 Karo technikos viršininko pastabos dèl š. m. mokymo Gaižiūnų poligone, LCVA, f. 929, ap. 3, b. 922, 1.75 a. p.; 1937-09-30 Šarvuočių rinktinès vado raportas karo technikos viršininkui, $L C V A$, f. 929, ap. 3, b. 987, 1. 58.
} 


\section{LIETUVOS KARIUOMENĖS TANKŲ PADALINIŲ PLÉTROS PLANAI}

Kaip šiame darbe jau ne kartą buvo minèta, Lietuvos kariuomenès lengvųjų tankų modeliai turèjo kelis pastebimus trūkumus. Ribotų galimybių tankų ginkluotė ir šarvinè apsauga („Renault FT 17“ dar ir mažas greitis) dare juos labai pažeidžiamus potencialaus priešo šarvuotosios technikos, jei tik ji buvo ginkluota ne vien sunkiaisiais kulkosvaidžiais. Negana to, Lietuvos kariuomenès turimų tankų nominalus skaičius (44 vienetai) buvo tiesiog per mažas. Šie trūkumai kariuomenëje neliko nepastebèti, ypač turint omenyje XX a. 4-ojo dešimtmečio antrojoje pusèje pablogejusią tarptautinio saugumo padèti Europoje ir konfliktus, galiausiai pasibaigusius Antruoju pasauliniu karu, kartu regiono valstybių kariuomenių, taip pat ir jų šarvuotųjų pajègų, augimą ir stiprejjimą. Dèl to šalies kariuomenès vadovybè ir karininkija, sekusi šarvuotụjų pajègų organizacijos, sudèties ir taktikos tendencijas įvairiose kariuomenèse ${ }^{225}$, pateikè nemažai planų ir pasiūlymų, kaip sustiprinti, modernizuoti Lietuvos tankų padalinius ir kartu visą kariuomenę, padidinti jos gynybinę galią. Dalis šių planų buvo pradèti igyvendinti.

Visų pirma galima pažymèti mėginimus sustiprinti pajègumus ir grąžinti kovinę vertę 1-ajai tankų kuopai, apginkluotai „Renault FT 17“ tankais. Šiuo klausimu 1936 m. karo technikos viršininkui savo pasiūlymus pateike Šarvuočių rinktinès vadas gen. št. plk. ltn. A. Sidabras ${ }^{226}$. Pasiūlymo esmę sudarè noras bent dalị prancūziškų tankų perginkluoti prieštankiniais pabūklais. Tai buvo būtina dèl to, kad „Renault FT 17“, net ir suremontuotais ir geresnius važiavimo duomenis leidžiančiais pasiekti varikliais, buvo per lèti ir per menkai ginkluoti, taigi kone bejègiai prieš

\footnotetext{
${ }^{225}$ Naujas tankų dalių statutas Jungtinèse Valstybėse, Kardas, Nr. 10, Kaunas, 1931, p. 155; Prancūzų, anglų, amerikiečių ir rusų tankų statutai, Kardas, Nr. 12, Kaunas, 1931, p. 179-185; Prancūzų tankų statuto II ir III dalys, Kardas, Nr. 12, Kaunas, 1932, p. 184-186; K. Z. B., Prieššarvinès apsaugos klausimu, Kardas, Nr. 17, Kaunas, 1936, p. 450-453; V. N., Tankų panaudojimas pagal naują anglų lauko tarnybos statutą, Mūsų žinynas, Nr. 8, Kaunas, 1937, p. 228-230; J. ltn. Ašmutaitis, Vengrų pažiūros ị tankelių panaudojimą, Mūsų žinynas, Nr. 4, Kaunas, 1938, p. 631-636.

${ }^{226}$ 1936-05-14 Šarvuočių rinktinès vado raportas karo technikos viršininkui, LCVA, f. 828 , ap. 1 , b. $109,1.33$.
} 
greitesnes ir sunkiau ginkluotas kovos mašinas, nuo kurių jie negalèjo nei pabėgti, nei apsiginti ${ }^{227}$. Be to, 1-ajai tankų kuopai iki visos sudeties (16 kovos mašinų) trūko 4 tankų. Todèl Šarvuočių rinktinès vadas pasiūle įsigyti 9 arba 6 „Renault FT 17“ (jei būtų įmanoma tai padaryti sumokant dvigubai ar trigubai mažiau nei už panašius "greituosius“ tankus), ginkluotus prieštankiniais pabūklais ${ }^{228}$. Atsižvelgiant ị i̇sigytųjų mašinų skaičių, tai leistų 1-ojoje tankų kuopoje suformuoti arba tris kautynių būrius ir vieną rezervo būrị (visuose būtų po 5 tankus), arba tris visos sudèties kautynių būrius su dar dviem tankais kuopos rezerve. Bet kuriuo atveju kuopoje dar buvo viena kovos mašina, skirta padalinio vadui, o kiekvienas tankų būrys turèjo turèti ne mažiau kaip du tankus, ginkluotus prieštankiniais pabūklais, kai likusieji ginkluoti senąja sunkiųjų kulkosvaidžių ginkluote. Negana to, siekiant dar labiau sutaupyti, buvo siūloma pasidomèti, ar nebūtų i̇manoma įsigyti pirkinio dalimis, kad vèliau būtų galima jas sumontuoti Šarvuočių rinktinès dirbtuvėse ${ }^{229}$.

Tų pačių metų rudeni gen. št. plk. ltn. A. Sidabras karo technikos viršininkui pateikè dar vieną, jau platesnị, raportą, kuriame pristatė ambicingesnị, tačiau, jo manymu, būtiną Lietuvos kariuomenès šarvuotụjų pajègų stiprinimo būdą ${ }^{230}$. Visų pirma atkreipiamas dèmesys, kad suintensyvejjo valstybių ginklavimosi procesas, kurio sudetine ir viena svarbiausių dalių yra investicijos ị karo aviacijos, motomechanizuotụjų pajègų, priešlèktuvinès ir prieštankinès apsaugos plètrą ir tobulinimą. Savo raporte Šarvuočių rinktinès vadas norèjo atkreipti dèmesị būtent ị priešiškų motomechanizuotụjų pajègų, ypač atsižvelgiant ị dviejų galingu ir nedraugiškų Lietuvai kaimyninių valstybių (turèta omenyje Lenkija ir Vokietija) keliamą grèsmę ir būdus jai pasipriešinti ${ }^{231}$. Pirmiausia konstatuota, kad Lietuvos kariuomenė yra prastai pasirengusi prieššarvinès apsaugos srityje. Svarbiausia, kad, rinktinès vado nuomone, kariuomenè neturi nieko, kas galètų efektyviai sustabdyti ị krašto gilumą prasiveržusius priešo motomechanizuotuosius junginius, galinčius padaryti ypač

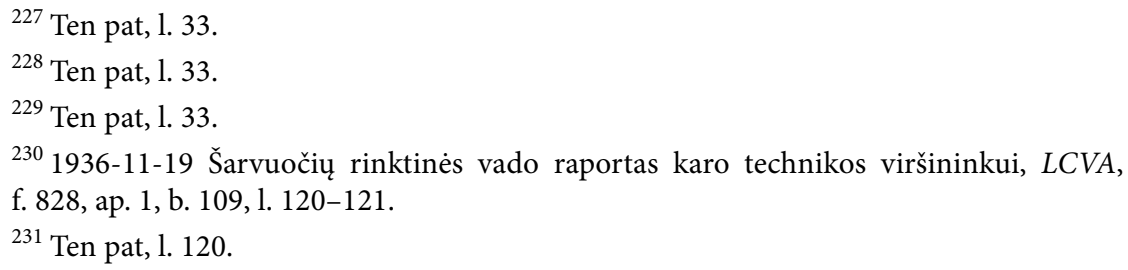


daug nuostolių, jei tai atsitiktų dar nesibaigus Lietuvoje mobilizacijai.

Kariuomenès daliniuose prieštankinių pabūklų turèta nedaug ir tie patys buvo nepakankamai judrūs, kad jais būtų galima suspèti užkirsti kelią šiai grèsmei, o pasyviosios užtvaros, t. y. inžinerinès kliūtys, greitai judančių motomechanizuotụjų dalinių galèjo būti palyginti nesunkiai apeitos $^{232}$.

Todèl, gen. št. plk. ltn. A. Sidabro įsitikinimu, kariuomenei veikiant plačiuose frontuose, vienintelè šią itin svarbią užduotị galètų atlikti tik sava motomechanizuotoji rinktinè. Jos formavimas ir jai reikalingos technikos ìsigijimas turi tapti prioritetiniu valstybès ginklavimosi programos punktu ${ }^{233}$. Ši rinktinè turètų būti kariuomenès rezervinis junginys, naudotinas prasiveržusiems priešo junginiams, taip pat ir motomechanizuotiesiems, kontratakuoti. Šarvuočių rinktinès vado siūlomą motomechanizuotajj junginị turejjo sudaryti: 1) štabas, 2) ryšių ir žvalgybos kuopa (apie 18 motociklų su priekabomis, iš kurių kai kurie būtų iš dalies šarvuoti ir ginkluoti kulkosvaidžiais, taip pat keli sunkvežimiai), 3) pèstininkų batalionas, judantis didesnio pravažumo pusiau šarvuotais sunkvežimiais, 4) trys tankų kuopos, iš kurių viena būtų aprūpinta mažiausio svorio tankais, ginkluotais tik kulkosvaidžiais (pvz., VCL), o dvi 6-8 t tankais, ginkluotais prieštankiniais pabūklais ir kulkosvaidžiais, 5) motorizuotoji artilerijos baterija (pageidautina, $105 \mathrm{~mm}$ haubicu), 6) motorizuotoji šešių prieštankinių pabūklų kuopa, 7) motorizuotasis priešlèktuvinių kulkosvaidžių būrys, 8) priešcheminès apsaugos būrys, 9) logistikos padaliniai ${ }^{234}$.

Toks visiškai ratine ir vikšrine karo technika aprūpintas ir ịvairias sausumos pajègų rūšis jungiantis dalinys turejo sugebèti palyginti greitai ivveikti didelius atstumus (net ir kai nèra gerų kelių), staigiai stoti ị mūṣ̨̌ ir sėkmingai kovoti kad ir su gausesnèmis priešo pajègomis ${ }^{235}$. Pažymètina, kad Šarvuočių rinktinès vado propaguojama motomechanizuotoji rinktinè turèjo būti naujas, nuolatinès sudèties kariuomenès dalinys, aprūpintas pažangesne karo technika, o ne improvizuotai suformuotas, staiga prireikus, iš esamų junginių.

\footnotetext{
232 Ten pat, 1. 120.

233 Ten pat, 1. 120.

234 Ten pat, 1. 121.

235 Ten pat, 1. 121.
} 
Pastarasis variantas, gen. št. plk. ltn. A. Sidabro manymu, būtų nepasiteisinęs, nes tuo metu kariuomenė stokojo kai kurių šiai rinktinei reikalingų specialių junginių, tinkamos karo technikos, parengtų veikti tokio dalinio sudètyje žmonių ${ }^{236}$. Šią nuomonę iš dalies patvirtino per $1935 \mathrm{~m}$. pratybas pirmą kartą kariuomeneje improvizuotai iš įvairių sausumos pajègų rūšių (įskaitant ir VCL būrị) suformuotos motomechanizuotosios rinktinès veiksmų išvados, kuriose pažymèta, kad šioms pajėgoms vadovaujantys vadai turi turèti atitinkamo darbo patirties, o ne improvi$z{ }^{2} \mathrm{ti}^{237}$. Šarvuočių rinktinès vadas norejo matyti kariuomenès sudètyje bent tris papildomas tankų kuopas, iš kurių dvi būtų tokios, kokių iki tol labiausiai trūko, - aprūpintos lengvaisiais tankais, ginkluotais galingesne ginkluote ir geriau šarvuotais, bet kartu gebančiais judèti dideliu greičiu ir galinčiais veiksmingai kovoti su priešo šarvuotąja technika. Tiesa, seniau suformuotos Šarvuočių rinktinei priklausančios tankų kuopos neturejo įeiti į motomechanizuotojo junginio sudètị, o, kaip anksčiau, remti pèstininkų ir kavalerijos dalinius ${ }^{238}$.

1937 m. kovą karo technikos viršininkas brg. gen. K. Popeliučka savo ruožtu pateikè raportą kariuomenès vadui, parengtą pavedus apsvarstyti tuo metu daug svarstymų sukèlusį naujų tankų pirkimo klausimą, to meto tankų taktines savybes ir naudojimo galimybes ${ }^{239}$.

Remdamasis savo surinkta medžiaga, brg. gen. K. Popeliučka išsamiai nušvietė tankų konstrukcijos raidos tendencijas nuo Pirmojo pasaulinio karo iki pat 1936 m. pabaigos, pabrèždamas, kad ši karo technikos rūšis buvo nuolat tobulinama ir stiprinama. Apibendrindamas jis nurodè, kad aptariamuoju laikotarpiu tankai buvo kone visuotinai skirstomi ị keturias grupes: tanketes, lengvuosius, vidutinius ir sunkiuosius tankus. Pirmųjų dviejų grupių kovos mašinos dèl mažų gabaritų ir didelio greičio labiausiai tiko žvalgyboje, taip pat, turint galingesnę ginkluotę, kitų kariuome-

\footnotetext{
${ }^{236}$ Ten pat, 1. 121 .

${ }^{237} \mathrm{Su}$ motomechanizuota rinktinèle Gaižiūnų poligono linkui, Kardas, Nr. 7, Kaunas, 1935, p. 157; Su motomechanizuota rinktinèle Tartoko kryptimi, Mūsu žinynas, Nr. 122, Kaunas, 1935, p. 509-513.

${ }^{238}$ 1936-11-19 Šarvuočių rinktinès vado raportas karo technikos viršininkui, LCVA, f. 828 , ap. 1 , b. $109,1.121$.

239 1937-03-23 Karo technikos viršininko raportas kariuomenès vadui, LCVA, f. 1364, ap. 1, b. 524, 1. 7-6 a. p.
} 
nès dalių paramai, priešo apejjimo manevrams vykdyti. Vidutiniai tankai, visapusiškai suderinti: turintys gana galingą ginkluotę, patikimą šarvinę apsaugą ir pasižymintys greičiu ir manevringumu, buvo universaliausi, kadangi kovos lauke galèjo sèkmingai kovoti su visomis galimomis grèsmėmis (taip pat ir kitais tankais), atlikti tiek įvairių ginklo rūšių paramos, tiek savarankiškas puolamąsias užduotis. Geriausiai šarvuoti ir ginkluoti (bet ir brangiausi) sunkieji tankai pirmiausia buvo skirti stipriai įtvirtintoms priešo gynybos pozicijoms pralaužti ${ }^{240}$.

Vertindamas, kokių naujų tankų modelių reikètų Lietuvos kariuomenei, karo technikos viršininkas iškart atmetè dèl didelès kainos sunkiųjų ir sunkesniųjų vidutinių tankų ịsigijimo galimybę. Kartu jis pažymėjo, kad tuo metu kariuomenès naujausi pirkiniai - lengvieji tankai (turèti omenyje VCL) dèl riboto veiksmingumo kulkosvaidžių ginkluotès labiausiai tinka žvalgybai ir kovai su riboto pajègumo priešu, tačiau visiškai negalètų pasipriešinti geriau ginkluotai šarvuotajai technikai ${ }^{241}$.

Tokią pat išvadą dèl ribotų šio tipo karo technikos kovinių pajègumų leido daryti ir tuo metu vykusio Ispanijos pilietinio karo eigą sekusiųjų

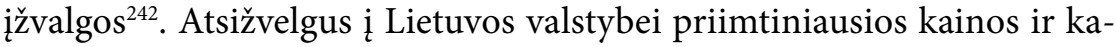
riuomenès prieššarvinių pajègumų stiprinimo būtinybès aspektus, siūlyta siekti ịsigyti naujų, geriau šarvuotų ir ginkluotų lengvųjų arba jiems techniškai artimų lengvesnio tipo vidutinių tankų.

Konkretindamas savo siūlymą, karo technikos viršininkas nurodè, kad naujoji technika turètų būti 6-7 t svorio, ginkluota mažiausiai vienu 20-37 mm pabūklu (jei galima, kartu su kulkosvaidžiu), turèti 13-20 mm storio šarvus ir, pageidautina, radijo ryšio įrangą, gebèti pasiekti $40-50 \mathrm{~km} /$ val. greiti, ivveikti 1,7-1,9 m pločio griovius. Nors raporte ir nebuvo kalbama apie konkrečius planuojamų įsigyti tankų skaičius, pažymètina, kad brg. gen. K. Popeliučka norèjo, kad kiekvienas tankų būrys taptų mišrios sudèties junginiu, kuriame šalia trijų lengvųjų tankų, jau esančių kariuomenès ginkluoteje ir ginkluotų tik kulkosvaidžiais, atsirastų du naujos konstrukcijos ir geriau ginkluoti lengvieji tankai. Tokie sustiprintos sudèties junginiai turejjo leisti laisviau ir lanksčiau juos panau-

\footnotetext{
240 Ten pat, 1. 7-6.

${ }^{241}$ Ten pat, 1. 6-6 a. p.

${ }^{242}$ Ltn. Čyžas, Tankai ispanų pilietiniame kare, Mūsų žinynas, Nr. 10, Kaunas, 1937, p. $487-488$.
} 
doti platesnėms nei iki tol kovinėms užduotims vykdyti ${ }^{243}$. Tuo pat metu, sekant užsienio karišką spaudą, pastebėta, kad tiek mažosios, tiek didžiosios valstybės, planuojančios gaminti ar įsigyti tankų, ypatingą dèmesi kreipe būtent ì panašios konstrukcijos, kokią apibūdino brg. gen. K. Popeliučka, gana universalios paskirties lengvuosius tankus. Apskritai būtent lengvieji tankai (kuriuos, atsižvelgiant ì techninių charakteristikų skirtumus, dar galima suskirstyti ị kelias smulkesnes grupes) aptariamuoju laikotarpiu sudarè didžiausią Europos kariuomenių šarvuotųjų pajègu dalị. Tokie tankai, ypač mažosioms valstybèms, buvo bene parankiausi dèl pirkimo ir eksploatacijos kainų ir kartu apčiuopiamai sustiprino kovinius pajejgumus ${ }^{244}$. Todèl manytume, kad Lietuvos kariuomenès įsigyti „Vickers-Carden Loyd“ iš principo atitiko bendrąsias tuometes šarvuotụjų pajègų plètros tendencijas, tačiau, deja, nepadèjo išspręsti prieššarvinių priemonių pajègumų sukūrimo Lietuvos tankų pajègose klausimo.

Bene ambicingiausią ir labiausiai išplètotą Lietuvos kariuomenès šarvuotujų pajègu plètros planą savo $1938 \mathrm{~m}$. balandžio raporte karo technikos viršininkui pasiūle Šarvuočių rinktinès vadas gen. št. plk. ltn. A. Sidabras $^{245}$. Jo nuomone, Lietuva gerokai atsilieka nuo daugumos kitų valstybių šarvuotųjų kovos mašinų (tankų ir šarvuočių) ginkluotosiose pajègose nuošimčiu. Todèl reikia siekti daugiau jų ịsigyti, kad kiekviena karo metu mobilizuota péstininkų divizija ar brigada turètų bent po vieną tankų kuopą, kiekvienas kavalerijos pulkas - po vieną mišrią šarvuočių ir tankų kuopą, kiekviena divizijos lengvoji rinktinė (DLR, pirmiausia žvalgybai skirtas, mobilizuojamas dalinys) - po vieną lengvụjų tankų būrị.

Tuo metu mobilizuotos Lietuvos kariuomenès sausumos pajègu pagrindą turèjo sudaryti 4 péstininkų divizijos, 2 péstininkų brigados (kiekvienas iš šių šešių dalinių turejo turèti, be kita ko, po vieną DLR) ir 3 kavalerijos pulkai ${ }^{246}$. Tiesa, suprasdamas, kad dèl Lietuvos ekonominès padėties neįmanoma greitai taip išplèsti šarvuotųjų pajėgų,

${ }^{243}$ 1937-03-23 Karo technikos viršininko raportas kariuomenès vadui, LCVA, f. 1364, ap. 1, b. 524, 1. 6 a. p.

${ }^{244}$ A. S., Tankai ir prieštankinė apsauga, Mūsų žinynas, Nr. 4, Kaunas, 1937, p. 457-458, 460-461.

245 1938-04-22 Šarvuočių rinktinès vado raportas karo technikos viršininkui, LCVA, f. 929-S, ap. 5, b. 448, 1. 35-36.

246 Ten pat, 1. 35 . 
gen. št. plk. ltn. A. Sidabras savo raporte pirmiausia pasiūlè kiek kuklesni šio plano variantą, perpus sumažinantị péstininkus turinčių remti kovos mašinų skaičių.

Šios sudèties Lietuvos kariuomene karo metu turèjo turèti mažiausiai 3 lengvụjų tankų kuopas pėstininkų diviziju paramai vykdyti, 2 lengvųjų tankų kuopas, skirtas išskirstyti būriais šešioms DLR, 2 lengvụjų tankų kuopas ir 1 šarvuočiu kuopą kavalerijos pulkų paramai užtikrinti ${ }^{247}$. Tuo metu kariuomenès arsenale buvusios šarvuotosios technikos kiekis gerokai skyrési nuo to, kurio pageidauta: péstininkų paramai - viena ne visos sudèties lengvụjų tankų (turimi omenyje „Renault FT 17“) kuopa, bendrai DLR ir kavalerijos pulkų paramai - iš viso dvi lengvụjų tankų (VCL) kuopos ir puse šarvuočių kuopos. Taigi, Šarvuočių rinktinès vado nuomone, iki modernios kariuomenès lygị atitinkančio šarvuotosios technikos kiekio Lietuvai trūko 32 lengvụjų tankų (dalis jų tuo metu jau buvo užsakyti Čekoslovakijoje) pėstininkų paramai užtikrinti, 32 lengvesnio modelio lengvụjų tankų (galbūt tokių kaip VCL) ir 6 lengvųjų žvalgybos šarvuočių kavalerijos ir DLR paramai vykdyti ${ }^{248}$.

Taikos metu, kad būtų patogiau mokyti, aprūpinti ir tvarkyti mobilizacijos reikalus, iš visų šių šarvuotųjų padalinių siūlyta sudaryti šarvuotąji pulką, formuotiną išplètus Šarvuočių rinktinę $e^{249}$. Tiesa, kad šio dalinio sudètis taikos metu pernelyg neišsiplèstų - neviršytų Šarvuočių rinktinès etatų ir neišaugintų su tuo susijusių išlaidų, dalis kuopų turèjo būti kadrinès (t. y. taikos metu ne visos sudeties, papildomos tik mobilizacijos metu rezervo kariais). Tad siūlomą šarvuočiu pulką turèjo sudaryti: 1) štabas, 2) 1-asis tankų batalionas, skirtas pestininkų dalinių paramai užtikrinti ir susidedantis iš vienos visos ir dviejų kadrinių tankų kuopų, 3) 2-asis šarvuotasis batalionas, skirtas kavalerijos pulkams remti ir susidedantis iš vienos lengvụjų tankų kuopos, vienos šarvuočių kuopos ir kadrinés lengvųjų tankų kuopos, 4) 3-iasis tankų batalionas, skirtas divizijų lengvosioms rinktinems remti ir susidedantis iš vienos iprastos ir vienos kadrinès lengvųjų tankų kuopos. Aptartoji struktūra, gen. št. plk. ltn. A. Sidabro manymu, turèjo atitikti Lietuvos kariuomenès

\footnotetext{
247 Ten pat, 1. 35 .

248 Ten pat, 1. 35-35 a. p.

249 Ten pat, 1.35 a. p.
} 
šarvuotųjų pajègų būtinajj minimumą ${ }^{250}$.

Nepasitikejjimo ir abejonių dèl Lietuvos kariuomenès tankų pajègų kovinių pajègumų ir tolesnio jų plètojimo perspektyvumo kilo 1939 m. rugsejjo $1 \mathrm{~d}$. Europoje prasidejus Antrajam pasauliniam karui. Šių abejonių šaltiniu tapo pirmojo šiame kare ginkluoto konflikto tarp nacistinès Vokietijos ir kaimyninès Lenkijos patirtis ir remiantis ja padarytos išvados. Lietuvos kariuomenès štabo I skyrius dar tais pačiais metais pateikè savo išvadas apie tuomet jau Lenkijos sutriuškinimu pasibaigusį karą su Vokietija ir, ịvertinęs pagrindinius ginkluotojo konflikto aspektus, kariavusių šalių strategiją ir taktiką, pateikè savo siūlymus ir rekomendacijas, kaip, atsižvelgiant ị naujojo karo diktuojamas sąlygas, reikètų pertvarkyti įvairius Lietuvos kariuomenès ir atskirų jos ginklo rūšių veiklos aspektus ${ }^{251}$.

Pirmiausia buvo atkreiptas dèmesys ị tai, kad abiejų potencialių Lietuvos priešų - Vokietijos ir Sovietų Sąjungos - galimi karo veiksmai turejo būti pagrịsti gausių ir sutelktų šarvuotųjų ir motomechanizuotųjų dalinių naudojimu giliems prasiveržimams ị priešo užnugarị vykdyti, siekiant apeiti ir galiausiai apsupti techniškai silpnesnes, todèl ne tokias paslankias oponuojančias pajègas (pavyzdžiui, Lietuvos kariuomenę) ${ }^{252}$. Isitikinęs, kad sèkmę kovos lauke tankai galèjo lemti tik sutelkti ł̇ didesnes pajègas (taip, kaip juos naudojo Vokietijos kariuomenè), Štabo I skyrius neigiamai vertino tolesnę Lietuvos tankų pajègų plètrą ${ }^{253}$. Remiantis šiuo požiūriu, Lietuvai derèjo visiškai atsisakyti naujų tankų issigijimo programų, kadangi ji finansiškai niekada neišgalès įsigyti jų tiek, kad galètų leisti sẻkmingai priešintis galimų priešų šarvuotosioms pajègoms. Užuot tai darius, reikètų lěšas investuoti i gerokai pigesnius už tankus prieštankinius artilerijos pabūklus ir jais sustiprinti prieššarvinius pajègumus. $O$ tankai ịvertinti (kaip ir karo aviacija) kaip per brangi Lietuvai karo technikos rūšis, kuri, negalint ísigyti reikiamo kiekio, neduos apčiuopiamos naudos, o jau kariuomenès turimi tankai gali būti naudingi tik ginantis už gamtinių kliūčių ir remiant pėstininkų divizijas ${ }^{254}$. Tiesa, karinèje spaudoje pasirodè

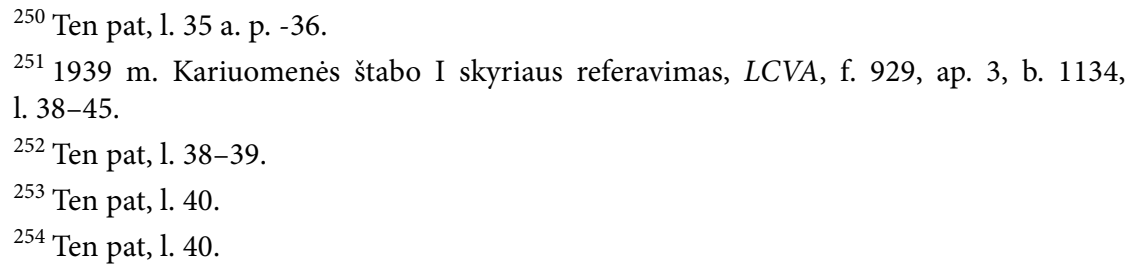


anoniminio Lietuvos šarvuotųjų pajègų atstovo nuomonè, prieštaraujanti tokioms kategoriškoms išvadoms ${ }^{255}$. Autorius teigè, kad net ir techniškai silpnesni ir ị ne tokius didelius vienetus sutelkti tankai (su sąlyga, kad bus atitinkamai apginkluoti), sumaniai naudojami, gali gintis nuo gausesnių priešo šarvuotụjų pajègų ne prasčiau už prieštankinius pabūklus.

Be to, tankai pranoko pastaruosius savo mobilumu, universalumu (gebejjimu greitai reaguoti ị besikeičiančią padètị kovos lauke, atlikti kur kas daugiau kovinių užduočių) ir puolamuoju potencialu, būtinu visapusiškiems motomechanizuotiesiems daliniams ${ }^{256}$. Lietuvos karinès vadovybès norą ir toliau stiprinti tankų pajègas liudijo ir 1939 m. pabaigoje - 1940 m. pradžioje pareikštas pageidavimas (kuris, tiesa, taip ir liko neịgyvendintas) iš Sovietų Sąungos įsigyti 20, o vèliau - 32 lengvuosius tankus T-26, ginkluotus $37 \mathrm{~mm}$ pabūklais ${ }^{257}$.

Naujasis Šarvuočių rinktinès vadas gen. št. plk. ltn. Pranas Grebliauskas 1940 m. pradžioje pateikè naujų savo vadovaujamo dalinio taikos ir karo metų etatų projektą ${ }^{258}$. Juo, be kita ko, buvo siekiama išplèsti Šarvuočių rinktinès sudètị ir labiau pritaikyti dalinị to meto kovos lauko sąlygoms. Visų pirma, planuojant ịsteigti batalionų vadų pareigybes, pabrěžta, kad tankų naudojimui smulkiais padaliniais karo sąlygomis galint pasirodyti neefektyviam, teko numatyti galimybę iš Šarvuočių rinktinės stipresnių padalinių karo atveju suformuoti kovinį tankų batalioną, kurio parengimu turèjo būti rūpinamasi dar taikos laikotarpiu ${ }^{259}$. Nors raporte tai ir nebuvo akcentuota, galima daryti prielaidą, kad šiuo pasiūlymu bandyta bent iš dalies įdiegti tankų naudojimo didesniais, sutelktais daliniais principą. Tam turejo pagelbèti ir ị rinktinès sudètị numatyti įtraukti du, rinktinès vado manymu, būtini padaliniai - priešlèktuvinè kuopa ir inžinierių (pionierių) būrys. Pirmasis iš jų turèjo būti atsakas ị Vokietijos ir Lenkijos karo metu aiškiai suvoktą karo aviacijos grèsmę sausumos vienetams. Be priešlèktuvinès apsaugos tankų junginių veiklai grẻsẻ būti pa-

\footnotetext{
255 Šarvuotininkas, Dèl straipsnio „Lenkijos katastrofos priežastys ir vokiečių-lenkų karo pamokos“, Kardas, Nr. 3, Kaunas, 1940, p. 65-67.

256 Ten pat, p. 66-67.

257 A. Pociūnas, A. Stoliarovas, Tankai Lietuvos kariuomeneje 1924-1940 m., p. 28.

${ }^{258}$ 1940-01-23 Gen. št. plk. ltn. P. Grebliausko raportas karo technikos viršininkui, LCVA, f. 828 , ap. 1 , b. $230,1.5-6$.

259 Ten pat, 1. 5 .
} 
ralyžiuotai. O inžinierių būrys turejo užtikrinti tankų dalinių mobilumą, šalindamas kliūtis jų kelyje, atlikti ardymo, sprogdinimo ir kitokias inžinerinių kliūčių naikinimo užduotis. Abu šie padaliniai organiškai turèjo priklausyti Šarvuočių rinktinei ir būti joje rengiami dar taikos metu ${ }^{260}$.

Pirmieji konkretūs svaresni sprendimai Lietuvos tankų pajègų stiprinimo klausimu buvo priimti $1937 \mathrm{~m}$. pirmojoje pusèje. Tų pačių metų pradžioje komisija, sudaryta iš Karo technikos tiekimo skyriaus viršininko plk. ltn. inž. Vinco Broniaus Aleksandravičiaus (pirmininko), to paties skyriaus plk. ltn. P. Masiulio ir ltn. Albino Griškevičiaus, karo technikos viršininko įsakymu apsvarsčiusi $8 \mathrm{t}$ svorio lengvųjų tankų pirkimo galimybes, rekomendavo îsigyti čekų firmos „Českomoravska-KolbenDanek“ (ČKD) siūlomą tanką TNH-L, kuriame galejo tilpti 3-4 žmonių igula, turintị 150-170 AG variklį, iki $25 \mathrm{~mm}$ storio šarvus ir ginkluotą vienu pabūklu ir dviem kulkosvaidžiais ${ }^{261}$. Didžiausias šio modelio konkurentas, regis, buvo švedų gamybos „Landsverk 60“ tankas. Tiesa, komisija įvertino, kad čekoslovakiškoji kovos mašina kai kuo pranoko konkurentą: jos šarvinè apsauga buvo tvirtesnè, tankas sklandžiau įveikdavo kliūtis (griovius, ikkalnes), jame buvo daugiau vietos igulai, patogesnès pavarų perjungimo ir vairavimo sistemos, galų gale jis buvo pigesnis. Kitais atžvilgiais abi konstrukcijos buvo apylygès ${ }^{262}$.

Prie tokios pat rekomendacinès išvados minèta komisija, tik papildyta dar vienu nariu - Šarvuočių rinktinès mjr. Alfonsu Jančiu, prièjo ir 1937 m. kovo mèn., dar kartą svarstydama šešių užsienio tankų gamintoju pasiūlymus ${ }^{263}$. Naujajai karo technikai buvo keliami šie principiniai reikalavimai: 1) ginkluote, susidedanti mažiausiai iš vieno pabūklo ir vieno kulkosvaidžio, 2) atsparūs automatinių prieššarvinių pabūklų iki $20 \mathrm{~mm}$ kalibro šūviams iš $300 \mathrm{~m}$ atstumo priešakiniai šarvai, 3) trijų žmonių ígulai ịrengtos vietos, 4) didelis greitis, geras manevringumas ir pravažumas. Pasak komisijos, geriausiai visus šiuos reikalavimus vèl atitiko firmos ČKD tankas LTL, kurị ir siūlyta įsigyti ${ }^{264}$. LTL buvo specialiai Lietuvai skirtas tanko modelis, kurị čekoslovakų firma suprojektavo pa-

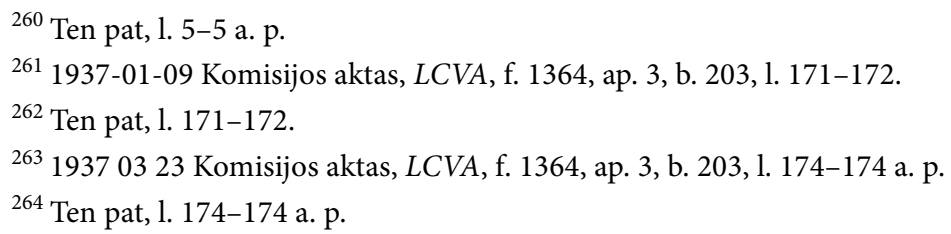


gal lietuvių pageidavimus modifikuodama tanką $\mathrm{TNH}^{265}$.

$1937 \mathrm{~m}$. gegužès $26 \mathrm{~d}$. Lietuvos kariuomenè su kompanija ČKD pasiraše 21 naujos konstrukcijos tanko ir atsarginių dalių jiems pirkimo už 12,9 mln. čekų kronų sutartị ${ }^{266} .1939$ m. sausio mèn. į Lietuvą išbandyti buvo pristatyti dviejų tankų modelių prototipai - pagal lietuvių pageidavimus suprojektuotas LTL ir Šveicarijos kariuomenei skirtas LTH. Galiausiai tụ pačių metų kovo $10 \mathrm{~d}$. po šių tankų prototipų bandymų Lietuvos atstovai nusprende pasirinkti ne specialiai Lietuvai sukurtą LTL, o pastarajam techninėmis savybėmis kiek nusileidusí, tačiau paprastesni variklị turintį LTH, kurio prototipo pagrindu turejo būti sukonstruotas naujas, patobulintas lengvojo tanko modelis LLT ${ }^{267}$.

Pagal 1939 m. liepos 1 d. parengtą ir tų pačių metų gruodžio 29 d. Lietuvos Vyriausybès patvirtintą $1937 \mathrm{~m}$. sutarties su ČKD pataisą, daugiausia susijusią su techninèmis tankų gamybos sąlygomis, Čekoslovakijos firma îsipareigojo visus tankus pagaminti ir paruošti prièmimui per devynis mènesius nuo $1939 \mathrm{~m}$. balandžio 20 d., kai turèjo būti pradèta serijinè LLT gamyba ${ }^{268}$. Naujieji Lietuvos kariuomenès tankai LLT turèjo būti 7,5 $\mathrm{t}$ svorio, $4,27 \mathrm{~m}$ ilgio, 1,98 $\mathrm{m}$ pločio, $2,15 \mathrm{~m}$ aukščio, gebèti ịveikti iki $1,9 \mathrm{~m}$ pločio griovius, $0,8 \mathrm{~m}$ aukščio stačias kliūtis, $0,9 \mathrm{~m}$ gylio vandens kliütis ir iki $45^{\circ}$ statumo ịkalnes. Šešių cilindrų, 128 AG, vandeniu aušinami benzininiai varikliai turejo padèti jiems pasiekti $48 \mathrm{~km} / \mathrm{val}$. greitị. Tanko priekinè dalis buvo apsaugota $25 \mathrm{~mm}$, šonai ir galas $-15 \mathrm{~mm}$, viršus ir dugnas - 6-10 mm storio šarvais. Trijų žmonių igulos valdomas LLT buvo ginkluotas $20 \mathrm{~mm}$ kalibro automatiniu pabūklu „Oerlikon“ (turinčiu 255-400 sviedinių atsargą) ir dviem 7,92 mm kalibro kulkosvaidžiais ZB vz. 37 (turinčiais 2600-3000 šovinių atsargą; taip pat buvo numatyta ji apginkluoti $37 \mathrm{~mm}$ kalibro pabūklu), aprūpintas teleskopiniu taikikliu ir radijo stotimi. Dalis šių kovos mašinų turejjo papildyti Šarvuočių rinktinès 3-iosios tankų kuopos (kaip minèta, nukentejjusios nuo gaisro Vilniuje $1939 \mathrm{~m}$. rudenį) sudètị, o likusios - ịsilieti ị naują, 4-ąją, tankų kuo-

\footnotetext{
${ }^{265}$ D. Bukelevičiūtè, Lietuvos ir Čekoslovakijos dvišalių santykių dinamika 1918-1939 metais, p. 240.

266 Ten pat, p. 240-241.

267 Ten pat, p. 242-243; A. Pociūnas, A. Stoliarovas, min. veik., p. 23.

${ }^{268}$ D. Bukelevičiūtè, Lietuvos ir Čekoslovakijos dvišalių santykių dinamika 1918-1939 metais, p. 243-244.
} 
$\mathrm{pą}^{269}$. Vèluojant gamybos darbams, pirmasis iš Lietuvos užsakytųjų tankų LLT buvo išbandytas 1940 m. gegužès pabaigoje - birželio pradžioje, o tų pačių metų liepą buvo surinkti ir sèkmingai išbandyti jau 16 šių tankų. Deja, bet naujųjų tankų gamybai artėjant prie pabaigos, $1940 \mathrm{~m}$. liepos 17 d. paaiškèjo, kad Čekoslovakiją 1939 m. okupavusi Vokietija atšaukè leidimą išvežti pagamintus tankus $s^{270}$. Todèl šių tankų, turèjusių lemti Lietuvos šarvuotųjų pajėgų aukštesnị kokybinị lygi, 1940 m. birželị Sovietų Sąjungos okupuotos Lietuvos kariuomenè jau nesulaukè.

Taigi, kaip matyti, aptariamuoju laikotarpiu Lietuvos karininkai pateikè ne vieną pasiūlymą, kuria linkme toliau reikètų vystyti kariuomenès tankų pajėgumus. Daugumoje šių planų buvo siūloma siekti kiekybinio ir, svarbiausia, kokybinio tankų pajègų šuolio, tobulinti jų dalinių organizaciją. Tolesnių darbų šia linkme svarbą diktavo supratimas, kad kariuomenès „Renault FT 17“ ir „Vickers-Carden Loyd“, visų pirma dèl savo ginkluotès, turi rimtų kovinio panaudojimo suvaržymų, be to, būtinai reikètų šarvuotąsias pajègas papildyti naujo modelio ir aukštesnio kovinio pajègumo lygio tankais, galinčiais savarankiškai efektyviai kovoti su vis didesne grèsme tampančia potencialių priešų šarvuotąja technika. Pagrindas teigiamiems pokyčiams šioje srityje igyvendinti buvo padètas 1937 m., Lietuvos kariuomenei užsakius čekoslovakų gamybos lengvųjų tankų, kurių pagrindinę ginkluotę jau turèjo sudaryti ne sunkusis kulkosvaidis, bet prieššarvinis pabūklas, o šarvinè apsauga bent iš dalies apsaugoti nuo šių ginklų ugnies. Tiesa, ketvirtojo dešimtmečio pabaigoje kilusio Antrojo pasaulinio karo metu pademonstruoti nauji karybos būdai sukèlè tam tikrų abejonių dẻl Lietuvos šarvuotųjų pajègų perspektyvų, tačiau bet kuriuo atveju galutinai jų ir kitų Lietuvos kariuomenès pajègų modernizaciją nutraukè sovietinė okupacija, kai buvo užgrobta nepriklausoma valstybè ir sunaikinta jos kariuomenè.

\footnotetext{
${ }^{269}$ A. Pociūnas, A. Stoliarovas, Tankai Lietuvos kariuomeneje 1924-1940 m., p. 25-26.

${ }^{270}$ D. Bukelevičiūtè, Lietuvos ir Čekoslovakijos dvišalių santykių dinamika 1918-1939 metais, p. 245-246.
} 


\section{IŠVADOS}

1. XX a. 4-ajame dešimtmetyje, Lietuvos kariuomenei siekiant papildyti tankų pajègas galingesnèmis kovos mašinomis, du kartus organizavus jų pirkimo konkursus, pavyko įsigyti 32 naujus mažiausio svorio kategorijos (iki 4 t) lengvuosius tankus. Jie buvo pasirinkti daugiausia dèl palankiausios kainos. Naujųjų tankų, atstovaujančių Europos valstybių kariuomenèse aptariamuoju laikotarpiu gana gausiai šarvuotųjų kovos mašinų klasei, buvo geras kainos ir kokybès santykis. Jie dèl savo techninių savybių puikiai tiko numatytoms užduotims atlikti. Be to, renkantis antrą kartą, šie tankai jau buvo išbandyti Lietuvos kariuomenejje, todèl atrodè, kad tai - racionalus pasirinkimas, net ir palyginti, regis, su pranašesniais, tačiau neišbandytais konkurentų modeliais.

2. Lietuvos kariuomenès ginkluotèje buvę „Renault FT 17“ ir „Vickers-Carden Loyd“ priklausė lengvụjų tankų kategorijai ir turejjo daug konstrukcijos panašumų. XX a. 4-ajame dešimtmetyje daugeli šių tankų persekiojo didesnès ar mažesnès techninès problemos, kurias sukeldavo tokios priežastys kaip konstrukcijos susidèvejimas, jos netobulumai, defektai ar netinkama priežiūra, eksploatacija. Prasta tankų techninè būklè kèlè didelę grèsmę, nes karo atveju daug ar net dauguma šių kovos mašinų tiesiog nebūtų pasiekusios kovos lauko arba nuolat gestų. Tiesa, kariuomenès vadovybė, suprasdama šios karo technikos svarbą ir žinodama, kokia ji brangi, dejjo visas pastangas, kad būtų atliekami atitinkami remonto darbai gerai šių kovos mašinų techninei būklei palaikyti ir joms grąžinti ị rikiuotę.

3. Sprendžiant tankų padalinių koviniam pajègumui itin svarbų mokymo klausimą susidurta su tokiomis problemomis kaip nepakankamas ì tarnybą priimtų naujokų išsilavinimas, netinkama jų sveikatos būklè ar dèl organizacinių netobulumų atsiradęs mažas galinčių dalyvauti mokymuose karių skaičius, nepakankamos mokymo priemonès, teorinio rengimo spragos. Visa tai, be abejo, atsiliepé tankų padalinių kovinei parengčiai, karių mokymo procesui, tankų techninei būklei. Tiesa, kariuomenès vadovybès pastangomis buvo bandyta mažinti aprūpinimo mokomosiomis priemonemis ir literatūra problemas. Šaudymo iš tankų pagrindinès ginkluotès programose ir planuose atsispindejo, kad pagrindiniais Lietuvos kariuomenès tankų taikiniais turejjo tapti priešo gyvoji 
jèga ir sunkioji ginkluotè, ypatingas dèmesys kreiptas ị taikinių apšaudymą tankams judant ir manevruojant. Nepaisant įvairių su šaudymu iš tankų sunkiųjų kulkosvaidžių susijusių sunkumų, pažymètina, kad pratybose dalyvavusių karių rezultatai buvo gana geri.

4. Lietuvos kariuomenès tankai buvo dviejų pagrindinių sausumos pajègų ginklo rūšių - pèstininkų ir kavalerijos - paramos ginklas, skirtas padèti sèkmingai igyvendinti jiems pavestas kovines užduotis, tad nebuvo numatyta, kad jie visiškai savarankiškai vykdys kovos veiksmus. Siekiant, kad kovos lauke visos ginklo rūšys remtų viena kitą, tankams labai svarbu buvo puolant sulaukti pėstininkų, kavalerijos ar artilerijos ugnies paramos. Bet per pratybas ir kariuomenès manevrus išryškejjo nemažai tankų padalinių kovinio bendradarbiavimo su sausumos pajėgų ginklo rūšimis problemų: kavalerijos ir péstininkų vadai buvo nepakankamai gerai susipažinę su tankų veikimo pagrindais ir techninemis savybèmis arba $\mathfrak{i}$ tai nekreipé demesio. Dèl to tankams buvo skiriamos netinkamos užduotys, nesuteikiama reikiama parama, nesuderinamas bendru veiksmų planas. Tiesa, tikslingas, netikètas priešui ir suderintas su pagrindinio kovinę užduotị vykdančio dalinio veiksmais tankų ịtraukimas $\mathfrak{j}$ kautynes pratybose baigdavosi sèkmingai. Pratybų praktika patvirtino, kad sèkmingai tankų veiklai kovos lauke svarbiausia buvo netikètumo veiksnys, gerai suderintas veiksmų su kitomis kariuomenès ginklo rūšimis planas ir sklandus jo vykdymas.

5. XX a. 4-ojo dešimtmečio antrojoje pusèje Lietuvos kariuomenès aukšti karininkai pateikè ne vieną pasiūlymą, kaip modernizuoti ir efektyviai stiprinti šarvuotąsias pajègas. Visus juos, nepaisant skirtingu detalių, jungè bendra mintis, kad Lietuvai reikia įsigyti didesnio kovinio pajègumo šarvuotųjų kovos mašinų, kadangi kariuomenès turimi tankai dèl savo nepakankamai galingos ginkluotès, neleidžiančios efektyviai kovoti su priešo šarvuotąja technika, turèjo pastebimų kovinio pajėgumo ir panaudojimo apribojimų. Atsižvelgiant ị tai, siūlyta ịsigyti naujos konstrukcijos, geriau šarvuotų, pabūklais ginkluotų, manevringų lengvųjų tanku. Dèl to 1937 m. Čekoslovakijoje buvo užsakyta pagaminti būtent šių bendrųjų savybių turinčių tankų LLT, bet jais, deja, papildyti Lietuvos kariuomenès nespèta.

Iteikta $2017 \mathrm{~m}$. spalio $31 \mathrm{~d}$. 


\title{
LES CHARS DE L'ARMÉE LITUANIENNE ET LEUR RÔLE DANS LES PLANS DE DÉFENSE DE L'ÉTAT DANS LES ANNÉES 30 DU XXE SIÈCLE
}

\author{
Šarūnas VOLUNGEVICIUS \\ Université Vytautas le Grand
}

Dans les années 30 du XXe siècle, afin de renforcer ses forces blindés, l'armée lituanienne a réussi en deux fois à acquérir au total 32 chars légers neufs "Vickers-Carden Loyd » de la catégorie de poids la plus légère. Le facteur prix très favorable a eu probablement l'impact le plus important sur leur choix. Les nouveaux chars représentaient la classe, assez nombreuse dans les armées européennes de l'époque, de véhicules blindés de combat à chenilles légers, rapides et manœuvrables, mais relativement peu blindés et armés, ils se distinguaient par un bon rapport qualité-prix, et leurs caractéristiques techniques convenaient bien aux missions qu'ils devaient effectuer. Par ailleurs, acheter ces chars une deuxième fois semblait être le choix le moins risqué car ils avaient déjà été testés dans l'armée.

Les « Renault FT 17 » de construction plus ancienne, déjà dans l'armée lituanienne, et les modèles nouvellement achetés " Vickers-Carden Loyd " appartenaient à la catégorie des chars légers. Dans les années 30, beaucoup de ces chars avaient fréquemment des problèmes techniques plus ou moins importants, provoqués par l'usure de la structure, ses imperfections, des défauts ou une mauvaise maintenance et exploitation des véhicules de combat. Le mauvais état technique des chars et les diverses pannes fréquentes compromettaient sérieusement les capacités des véhicules de combat à fonctionner efficacement non seulement lors des exercices, mais aussi lors d'un éventuel conflit militaire. Il est vrai que, comprenant l'importance et le prix élevé de ce matériel militaire, l'armée faisait des efforts permanents et, dans de nombreux cas, réussis pour résoudre ces problèmes grâce à des travaux de réparation et de maintenance technique appropriés.

Le processus de la formation de militaires particulièrement important pour la capacité de combat des unités de chars était entravé par le niveau éducatif des nouvelles recrues souvent insuffisant, leur état de santé ou le faible nombre de militaires pouvant participer aux exercices qui était déterminé par des défauts d'organisation ainsi que des moyens de formation insuffisants et les lacunes de la préparation théorique. Tous ces problèmes avaient, sans doute, un impact négatif 
sur la préparation au combat des unités blindées, par conséquent cela obligeait à faire des efforts pour améliorer la qualité de la formation des militaires des forces blindées. En matière de formation au tir de mitrailleuses lourdes, principal armement des chars de l'armée lituanienne, nous voyons que les principales cibles de ces véhicules de combat devaient être les soldats de l'ennemi et son armement lourd, en mettant l'accent sur le mouvement et les manœuvres des chars lors de l'attaque.

Les chars de l'armée lituanienne étaient une arme de support des deux principales catégories d'armes des forces terrestres, l'infanterie et la cavalerie, qui était destinée à aider ces dernières à effectuer les missions de combat confiées, et ils nétaient donc pas prévus pour des actions de combat entièrement autonomes. Par ailleurs, il était très important lors d'une attaque que les chars obtiennent le support du feu de l'infanterie, de la cavalerie ou de l'artillerie ou bien un support d'autre nature. Les exercices et les manœuvres de l'armée ont permis de mettre en lumière un certain nombre de problèmes qui apparaissaient dans la coordination des chars avec les principales catégories d'arme, comme une trop faible connaissance par les commandants de la cavalerie ou de l'infanterie des bases du fonctionnement des chars et de leurs caractéristiques techniques, ou une négligence de ces principes. Cela a déterminé que des missions inappropriées étaient affectées aux chars, le support nécessaire nétait pas apporté et des plans d'actions communes nétaient pas coordonnés. C'est vrai qu'en même temps l'introduction au combat des chars ciblée, inattendue pour l'ennemi et coordonnée avec les actions des autres unités de combat se terminait avec succès dans les exercices. Les exercices confirmaient que, pour une action réussie des chars sur le champ de bataille, le facteur de surprise, un plan d'actions bien coordonné avec les autres forces et son exécution étaient le plus important.

Dans la deuxième moitié des années 30 , certains officiers supérieurs de l'armée lituanienne ont fait des propositions pour renforcer les forces blindées. Malgré des détails divergents, elles étaient unies par l'idée que la Lituanie avait besoin de véhicules blindés d'un niveau de capacité de combat plus élevé qui, contrairement aux anciens chars utilisés dans l'armée, seraient capables de combattre efficacement un matériel blindé ennemi similaire. Compte tenu de cela, il a été proposé d'acquérir des chars légers de nouvelle construction, mieux blindés, armés de canons et manœuvrables. À vrai dire, les chars LLT, conformes à ces exigences et commandés par l'armée, n’ont pas eu le temps de rejoindre les forces blindées de la Lituanie. 


\title{
LITHUANIAN MILITARY TANKS AND THEIR ROLE IN THE NATIONAL DEFENSE PLANS OF THE 4TH DECADE OF THE 20TH CENTURY
}

\author{
Šarūnas VOLUNGEVIČIUS \\ Vytautas Magnus University
}

In the 4 th decade of the 20th century, the Lithuanian Army, in order to strengthen its tank forces, twice implemented the purchase of 32 new Vickers-Carden Loyd light tanks. The most favourable factor for their choice was their price. The new tanks represented the then model of the European armies with a relatively large unit of light, fast, maneuverable but relatively easy armoured and armed combat crawler machines sold by good pricequality ratio, and their technical characteristics were well suited to the tasks they were supposed to perform. In addition, when choosing these tanks for the second time, they had already been tested in the army, and seemed to be the least risky option.

The older Renault FT 17 which was part of the Lithuanian Army and the newly acquired tanks of the Vickers-Carden Loyd model belonged to the category of light tanks. In the $4^{\text {th }}$ decade of 20th century, many of these tanks were haunted by technical problems, both big and small, caused by the wear and tear of a structure, imperfections, defects or improper maintenance and operation of the combat machines. Such poor technical condition of the tanks, and various permanent failures seriously affected the ability of combat machines to function effectively not only during exercises but also during a possible military conflict. What is true, is that the staff of the military forces, understanding the importance and value of the war machines, made great efforts, which in many cases were successful, to solve the problems above by appropriate repair and maintenance work.

The training of soldiers was of particular importance in combating the capabilities of the tank divisions, however, it was hampered by common circumstances such as the low level of education of new recruits, the state of their health or organizational imperfections related to training, including low capacities which allowed participation of only a comparatively small number of soldiers in the training, lack of training means, and gaps in theoretical training. Undoubtedly, all of these problems had a negative impact on the combat readiness of tanks, and motivated efforts to improve the quality 
of training soldiers operating the armoured vehicles. Training shooting practice involved heavy machine guns, which were the main ammunition in the tank divisions of the Lithuanian Army, revealed that the main target of these combat vehicles could have been the enemy's living force and its heavy weaponry, and consequently the movement of tanks and manoeuvring during an attack was emphasized.

The Lithuanian Army's tanks were used to support two main types of land forces - infantry and cavalry - in order to help them complete their combat missions and for this reason were not foreseen for fully independent combat action. In addition, it was very important for tanks to receive the infantry, cavalry or artillery fire, and other types of combat support during an attack. The exercises and army maneuvers helped to highlight a number of the problems that arise in the combat cooperation of tank divisions with the other divisions that used the main types of weapons. These problems were the lack of knowledge of cavalry and infantry commanders regarding the basics of operation and technical characteristics of the tanks, and their disregard of them. This led to the inappropriate assignment of tanks, the lack of necessary support, and the lack of coordination of the joint action plan. Meanwhile, the purposeful - and unexpected for the enemy - introduction of combat tanks in fighting, and their actions coordinated with the other combat units proved to be successful during exercises. The military exercises confirmed that successful activities of the tanks in the field were mainly based on the element of unexpectedness, and a well-coordinated plan for action with the other forces, and its implementation.

In the second half of the 1940s, the Lithuanian army's high-ranking military forces officers came up with proposals to strengthen the armoured forces, and despite small differences in opinions, they admitted that there was a need for Lithuania to have armoured combat vehicles representing a higher level of combat capability, which, unlike the forces already in service, would be capable of effectively combating similar armoured vehicles of the enemy. In view of this, it was proposed to purchase the new type light tanks that were better armoured and armed, and maneuverable. LLT tanks compliant with the mentioned requirements were ordered by the Army, however, there was not sufficient time to supplement the composition of the Lithuanian armoured forces. 